\title{
ipen
}

AUTARQUIA ASSOCIADA À UNIVERSIDADE DE SÃO PAULO

\section{LICENCIAMENTO DE REATORES : PROPOSTA DE UMA ESTRUTURA REGULATÓRIA INTEGRADA COM ABORDAGEM EM QUALIDADE E MEIO AMBIENTE PARA REATORES DE PESQUISA NO BRASIL}

\author{
Reynaldo Cavalcanti Serra
}

\author{
Tese apresentada como parte dos \\ requisitos para obtenção do Grau de \\ Doutor em Ciências na Área de Tecnologia \\ Nuclear - Aplicações \\ Orientadora: \\ Profa. Dra. Désirée Moraes Zouain
}




\title{
INSTITUTO DE PESQUISAS ENERGÉTICAS E NUCLEARES
}

Autarquia associada à Universidade de São Paulo

\section{LICENCIAMENTO DE REATORES : PROPOSTA DE UMA ESTRUTURA REGULATÓRIA INTEGRADA COM ABORDAGEM EM QUALIDADE E MEIO AMBIENTE PARA REATORES DE PESQUISA NO BRASIL}

\author{
Reynaldo Cavalcanti Serra \\ Tese apresentada como parte dos \\ requisitos para obtenção do Grau de \\ Doutor em Ciências na Área de Tecnologia \\ Nuclear - Aplicações \\ Orientadora: \\ Profa. Dra. Désirée Moraes Zouain
}

Versão Corrigida

Versão Original disponível no IPEN

São Paulo

2014 


\section{Dedicatória}

Dedico este trabalho aos aos meus pais, esposa, filhos e netas, pelo incentivo e compreensão que impulsionaram meu ideal a conquistar esta realidade. 


\section{Agradecimentos}

Agradeço imensamente a Professora Dra. Désirée Moraes Zouain pela paciência, orientação precisa e objetiva durante o desenvolvimento desta pesquisa e, principalmente, nos momentos decisivos, essenciais para conclusão do trabalho.

Agradeço aos Drs. Nelson Meldonian e Luis Antonio Terribile Mattos que, com suas experiências no tema da pesquisa, trouxeram valorosas contribuições para o conhecimento detalhado dos processos de licenciamento de reatores nucleares de pesquisa no Brasil.

Agradeço à Dra. Linda Caldas por apoiar o desenvolvimento desta pesquisa.

Agradeço às pessoas que me receberam para entrevistas e responderam o instrumento de pesquisa, colaborando e contribuindo com informações preciosas para a realização desta pesquisa.

Por fim, agradeço à minha esposa Berenice, portadora da vitória, que com sua compreensão e ilimitada paciência, fatores permeadores de nossas vidas, permitiu que um dos principais ideais de minha vida se tornasse realidade. 


\section{Epígrafe}

"Mantenha suas palavras positivas, porque suas palavras tornam-se suas atitudes. Mantenha suas atitudes positivas, porque suas atitudes tornam-se seus hábitos. Mantenha seus hábitos positivos porque seus hábitos tornam-se seus valores. Mantenha seus valores positivos, porque seus valores tornam-se seu destino" 


\title{
LICENCIAMENTO DE REATORES: PROPOSTA DE UMA ESTRUTURA REGULATÓRIA INTEGRADA COM ABORDAGEM EM QUALIDADE E MEIO AMBIENTE PARA REATORES DE PESQUISA NO BRASIL
}

\author{
Reynaldo Cavalcanti Serra
}

\section{RESUMO}

\begin{abstract}
Este trabalho apresenta uma proposta para implementação de uma estrutura regulatória integrada com abordagem em qualidade e meio ambiente no processo de licenciamento de reatores nucleares de pesquisa no Brasil. A proposta foi desenvolvida a partir do estudo de processos de licenciamento de reatores nucleares de pesquisa de diversos países Membros da Agência Internacional de Energia Atômica. Após esta fase, realizou-se um estudo comparativo destes processos com o processo de licenciamento de reatores nucleares de pesquisa Brasileiro, para identificação boas práticas (aspectos positivos), possíveis lacunas existentes e então apresentar uma proposta para gestão integrada em qualidade e meio ambiente, com o objetivo de contribuir com um novo esquema para o processo de licenciamento no Brasil. A revisão da literatura considerou os seguintes reatores nucleares de pesquisa: Jules-Horowitz e OSIRIS (França), Hanaro (Coréia do Sul), Maples 1 e 2 (Canada), OPAL (Austrália), Pallas (Holanda), ETRR-2 (Egito) e IEA-R1 (Brasil). O atual processo de licenciamento de reatores nucleares de pesquisa é conduzido por dois órgãos regulatórios: a Comissão Nacional de Energia Nuclear (CNEN) e o Instituto Brasileiro do Meio Ambiente e dos Recursos Renováveis (IBAMA). A CNEN é responsável pelas questões nucleares, enquanto o IBAMA pelas questões ambientais. Para apoiar o trabalho, foram aplicados um instrumento de pesquisa e entrevistas, construídas com base na atual estrutura regulatória adotada para os quatro reatores de pesquisa existentes no Brasil. Atualmente, o processo de licenciamento nuclear para reatores de pesquisa no Brasil possui seis fases e o processo ambiental somente três fases. Um estudo da correlação entre estas fases fundamentou a proposta de uma nova estrutura regulatória integrada em qualidade e meio ambiente com quatro fases harmonizadas, reduzindo potencialmente os atrasos nos processos de licenciamento de reatores nucleares de pesquisa.
\end{abstract}




\title{
REACTORS LICENSING: PROPOSAL OF AN INTEGRATED QUALITY AND ENVIRONMENT REGULATORY STRUCTURE FOR NUCLEAR RESEARCH REACTORS IN BRAZIL
}

\author{
Reynaldo Cavalcanti Serra
}

\begin{abstract}
A new integrated regulatory structure based on quality and integrated issues has been proposed to be implemented on the licensing process of nuclear research reactors in Brazil. The study starts with a literature review about the licensing process in several countries, all of them members of the International Atomic Energy Agency. After this phase it is performed a comparative study with the Brazilian licensing process to identify good practices (positive aspects), the gaps on it and to propose an approach of an integrated quality and environmental management system, in order to contribute with a new licensing process scheme in Brazil. The literature review considered the following research nuclear reactors: Jules-Horowitz and OSIRIS (France), Hanaro (Korea), Maples 1 and 2 (Canada), OPAL (Australia), Pallas (Holand), ETRR-2 (Egypt) and IEAR1 (Brazil). The current nuclear research reactors licensing process in Brazil is conducted by two regulatory bodies: the Brazilian National Nuclear Energy Commission (CNEN) and the Brazilian Institute of Environment and Renewable Natural Resources (IBAMA). CNEN is responsible by nuclear issues, while IBAMA by environmental one. To support the study it was applied a questionnaire and interviews based on the current regulatory structure to four nuclear research reactors in Brazil. Nowadays, the nuclear research reactor's licensing process, in Brazil, has six phases and the environmental licensing process has three phases. A correlation study among these phases leads to a proposal of a new quality and environmental integrated licensing structure with four harmonized phases, hence reducing potential delays in this process.
\end{abstract}




\section{SUMÁRIO}

\section{Página}

1 INTRODUÇÃO

1.1 Contextualização e identificação do problema

2 OBJETIVOS E CONTRIBUIÇÕES ORIGINAIS

2.1Objetivo principal

2.2 Objetivos específicos

2.3 Premissas

2.4 Contribuições originais

3 REVISÃO DA LITERATURA

3.1 Reatores de pesquisas nucleares no mundo

3.2 Reatores de pesquisas nucleares no mundo e seus

processos de licenciamento

4 METODOLOGIA DA PESQUISA

4.1Método da pesquisa

4.2Detalhamento da pesquisa

4.3Instrumento de pesquisa

5 RESULTADOS 
6.1Análise comparativa entre os modelos regulatórios brasileiros nuclear e ambiental

6.2Análise dos resultados da pesquisa de campo

6.2.1Reator de Pesquisa IEA-R1

6.2.2 Reator IPEN/MB-01

6.2.3Reator de Pesquisa Argonauta

6.3Análise comparativa do modelo regulatório brasileiro com o modelo da agência internacional de energia atômica e os resultados da pesquisa de campo

6.3.1 O modelo da AIEA

6.3.2 Análise e discussão entre os modelos da AIEA - CNEN- Resultados da pesquisa

7 PROPOSTA DE UMA ESTRUTURA REGULATÓRIA INTEGRADA

8 CONCLUSÕES E RECOMENDAÇÕES

APÊNDICE A - Instrumento de Pesquisa 


\section{LISTA DE TABELAS}

Página

TAB. 1 - Reatores de Pesquisa - Países Membros da AIEA - Situação

Operacional

TAB. 2 - Tempos médios despendidos por órgãos regulatórios de diversos países

TAB. 3 - Matriz Comparativa - Fases dos Processos de Licenciamento AIEA e Países-Membros

TAB. 4 - Correlação das dimensões com as etapas dos processos de licenciamento nuclear e ambiental

TAB. 5 - Aplicação do método científico hipotético-dedutivo e científico e a sua correlação com as etapas desenvolvidas neste trabalho

TAB. 6 - Dados informativos das instalações em que o questionário de pesquisa foi aplicado

TAB. 7 - Resultados da pesquisa de campo

TAB.8 - Matriz de correspondências entre as etapas dos modelos regulatórios brasileiros nuclear e ambiental

TAB.9 - Matriz comparativa do modelo da AIEA com o modelo regulatório brasileiro (nuclear e ambiental) e os resultados da pesquisa de campo

TAB.10 - Pressupostos para proposta da estrutura integrada e as questões de pesquisa

TAB. 11 - Matriz da proposta para a estrutura regulatória integrada 


\section{LISTA DE FIGURAS}

Página

FIG. 1 - Diagrama simplificado para obtenção do licenciamento de reatores de pesquisa nuclear no Brasil. Situação atual

FIG. 2 - Fluxo de Atividades - Procedimento para Licenciamento de Reatores na Coréia do Sul, aprovação do local para construção

FIG. 3 - Fluxo de Atividades - Procedimento para Licenciamento de Reatores na Coréia do Sul - Permissão para Construção

FIG. 4 - Fluxo de Atividades - Procedimento para Licenciamento de Reatores na Coréia do Sul - Licença de Operação

FIG. 5 - Estrutura regulatória nuclear da Coréia do

FIG. 6 - Etapas do Método Hipotético-Dedutivo Segundo Popper

FIG. 7- Fluxograma simplificado com modelo de licenciamento considerando a estrutura regulatória integrada proposta neste trabalho

FIG. 8 - Detalhamento da Pesquisa

FIG. 9 - Instrumento de Pesquisa - dimensões e subdimensões 


\section{ABREVIATURAS}

ABNT- $\quad$ Associação Brasileira de Normas Técnicas

AEA- $\quad$ Autoridade em Energia Atômica

AIEA- $\quad$ Agência Internacional de Energia Atômica

AECB- Atomic Energy Control Board

AECL- $\quad$ Atomic Energy of Canada Limited

ANSTO- Australian Nuclear Science and Technology Organization

AOl- $\quad$ Autorização de Operação Inicial

AOP- $\quad$ Autorização de Operação Permanente

ARPANSA- Australian Radiation Protection and Nuclear Safety Agency

AUMAN- $\quad$ Autorização para Utilização de Material Nuclear

CEA- Commissariat à l'Énergie Atomique

CNEN- Comissão Nacional de Energia Nuclear

CNSC Canadian Energy Safety Commission

CONAMA- Conselho Nacional do Meio Ambiente

CP- Permissão de construção

CSP- Commission de Sûreté des Piles

DSN- Departamento de Segurança Nuclear

EIA- $\quad$ Estudo de impacto ambiental

FUNAI- $\quad$ Fundação Nacional do Índio

HFR- High Flux Reactor

IBAMA- Instituto Brasileiro do Meio Ambiente e dos Recursos Naturais Renováveis

IAEA- International Atomic Energy Agency

IPHAN- Instituto do Patrimônio Histórico e Artístico Nacional

INMETRO- Instituto Nacional de Metrologia, Qualidade e Tecnologia

IPEN- Instituto de Pesquisas Energéticas e Nucleares

IPSN- Instituto de Proteção e de Segurança Nuclear

ISO- International Organization for Standardization

KAERI- Korea Atomic Energy Research Institute 
LI- Licença de Instalação

LO- L L Licença de Operação

LP- Licença Prévia

MAPLE- $\quad$ Multipurpose Applied Physics Lattice Experiment

NCNSRC- National Center for Nuclear Safety and Radiation Control

NRG- $\quad$ Nuclear Research and Consultancy Group

NRU- $\quad$ Nuclear Research Universal

OEMA- $\quad$ Orgão Estadual do Meio Ambiente

OHSAS- Occupational Health and Safety Assessment Services

OPAL- $\quad$ Open Pool Australian Light-water Reactor

PBA- $\quad$ Plano Básico Ambiental

PSAR- $\quad$ Preliminary Safety Analysis Report

RA- Relatório Ambiental

RAS- Relatório de Análise de Segurança

RRDB- $\quad$ Research Reactor Data Base

RFAS- $\quad$ Relatório Final de Análise de Segurança

RIMA- Relatório de Impacto Ambiental

RPAS- Relatório Preliminar de Análise de Segurança

SCSIN- Serviço Central de Segurança de Instalações Nucleares

SWOT- $\quad$ Strengths, Weaknesses, Opportunities, Threats (Forças, Fraquezas, Oportunidades e Ameaças) 


\section{INTRODUÇÃO}

Reatores de pesquisas nucleares são instalações complexas que envolvem riscos e impactos relacionados à segurança e ao meio ambiente. Esses riscos e impactos, decorrentes das atividades operacionais dessas instalações, devem ser identificados e avaliados antes e durante a construção destes empreendimentos para que sejam estabelecidos procedimentos, controles e monitorações que permitam uma operação regular, prevenindo impactos que possam afetar o meio ambiente e à população.

Os riscos e impactos relacionados à operação dessas instalações são profundamente estudados para identificar, avaliar e estabelecer procedimentos que definirão os controles e monitorações dos aspectos relacionados às suas atividades, seus processos operacionais e constituem um processo legal e mandatório denominado "processo de licenciamento".

O processo de licenciamento de reatores nucleares tem como finalidade verificar e atestar o cumprimento de todos os requisitos técnicos e regulatórios que envolvem as instalações nucleares para preservar a integridade da instalação nuclear durante a sua construção e operação, com o objetivo principal de proteger trabalhadores, população e meio ambiente (Rozental,1986).

No Brasil, os reatores nucleares, quer sejam para pesquisas quer sejam para geração de energia elétrica, somente podem iniciar suas atividades após obterem as licenças de operação nuclear e ambiental, que são emitidas por órgãos regulatórios distintos, CNEN (Comissão Nacional de Energia Nuclear) para a licença nuclear e IBAMA (Instituto Brasileiro do Meio Ambiente e dos Recursos Renováveis) para a licença ambiental, cada um na sua área de competência, conforme apresentado na FIG.1.

Isto significa que um empreendimento nuclear para pesquisa deve desenvolver dois processos de licenciamento distintos e independentes, com legislações, regulamentos, normas técnicas e metodologias estabelecidas por órgãos regulatórios diferentes, que emitem licenças por períodos de tempo também distintos e independentes. 
Na CNEN, a formalização do processo de operação ocorre com a emissão do documento denominado "Autorização para Operação Permanente", enquanto a formalização da aprovação do cumprimento regulatório ambiental ocorre com a emissão do documento denominado "Licença de Operação".

\subsection{Contextualização e Identificação do Problema}

A condução de dois processos de licenciamento praticamente independentes faz com que ocorram excessos de controles, duplicação de esforços, lacunas normativas e regulatórias que podem tornar, frequentemente, o licenciamento de reatores nucleares de pesquisa um processo gerador de atrasos e falhas.

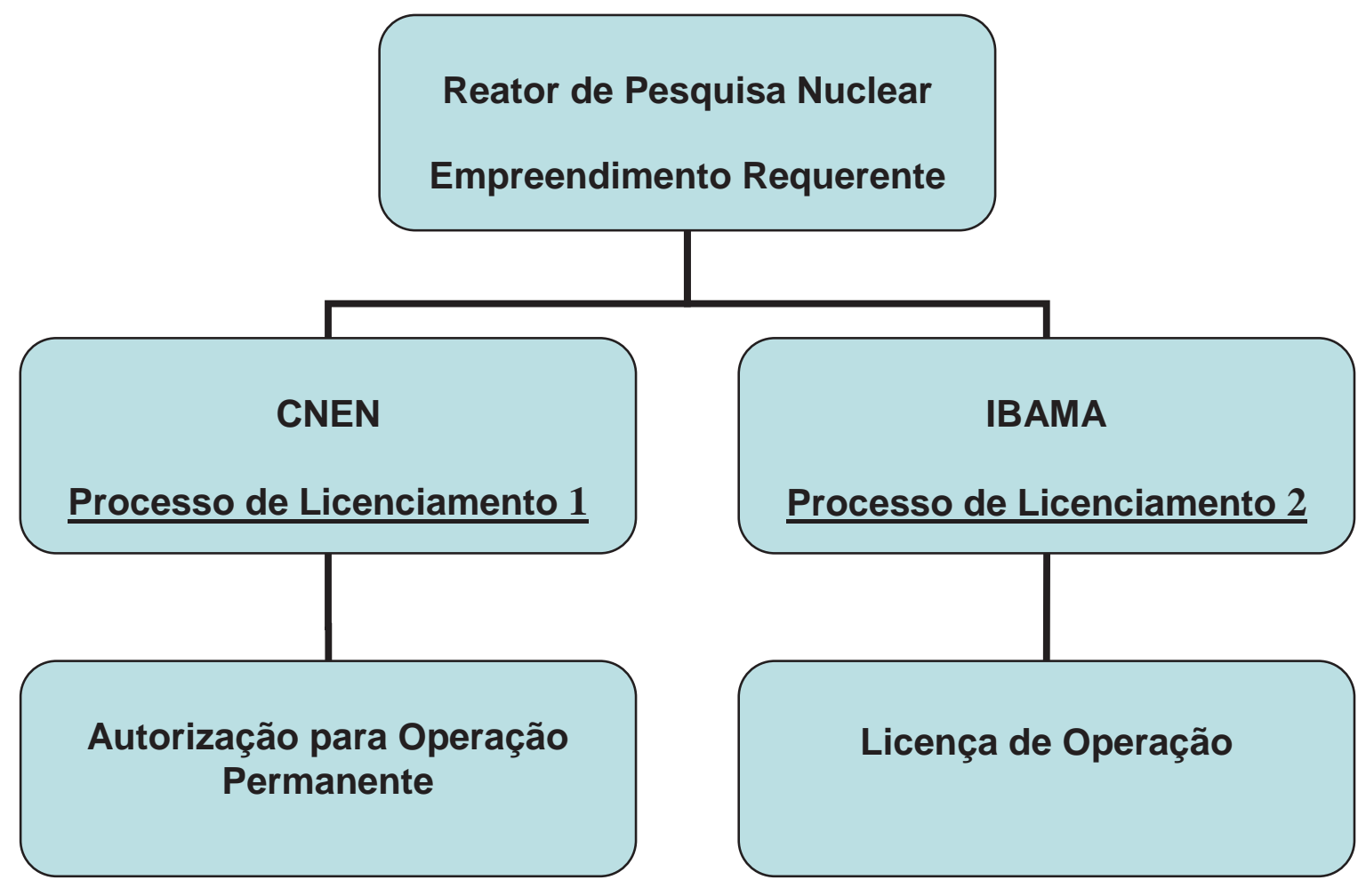

FIGURA 1 - Diagrama simplificado para obtenção do licenciamento de reatores de pesquisa nuclear no Brasil. Situação atual.

Atualmente, o cenário nacional é composto por quatro reatores de pesquisa nucleares, cujos processos de licenciamento foram conduzidos com metodologias diferentes daquela recomendada pela AIEA - Agência Internacional de Energia Atômica, 
o que foi também um dos fatores motivadores para a realização deste trabalho. Além disso, os conflitos existentes nas questões ambientais entre os processos de licenciamento conduzidos pela CNEN e pelo IBAMA geram a oportunidade para a proposição de uma estrutura regulatória integrada em qualidade e meio ambiente que poderia vir a ser adotada nos processos de licenciamento de reatores de pesquisa nucleares.

A presente pesquisa está dividida em três fases:

- A primeira fase tem como objetivo estudar os processos de licenciamento de diversos reatores nacionais e em diversos países membros da AIEA, detalhando as fases dos processos de licenciamento e as estruturas regulatórias disponíveis, e elaborar uma matriz comparativa que servirá como base para a fase seguinte da pesquisa;

- A segunda fase consiste na preparação, aplicação e análise dos resultados obtidos com os estudos dos processos de licenciamento dos reatores de pesquisas nucleares nacionais;

- A terceira e última fase caracteriza-se pela proposição de uma estrutura regulatória integrada com a abordagem em qualidade e meio ambiente, trazendo uma contribuição para o caso brasileiro.

O texto está estruturado em oito capítulos. No capítulo 1 é feita a introdução ao tema com a justificativa para a escolha do mesmo por parte deste pesquisador. No capítulo 2 é apresentada a contextualização da pesquisa, seus objetivos, as questões da pesquisa, suas premissas e contribuições originais. No capítulo 3 é abordada a revisão da literatura. No capítulo 4 é apresentada a metodologia da pesquisa. No capítulo 5 são apresentados os resultados. No capítulo 6 são realizadas a análise e discussão dos resultados obtidos com a identificação dos subsídios para o desenvolvimento da proposta referente à terceira fase da pesquisa. No capítulo 7 é apresentada a proposta de estrutura regulatória integrada. No capítulo 8 são apresentadas as conclusões e recomendações. A estrutura do texto apresenta ainda as referências bibliográficas utilizadas no trabalho e a bibliografia de apoio utilizada como suporte técnico para seu desenvolvimento. 


\section{OBJETIVOS, PREMISSAS E CONTRIBUIÇÕES ORIGINAIS}

\subsection{Objetivo Principal}

O objetivo principal deste trabalho é propor uma estrutura regulatória integrada com abordagem em qualidade e meio ambiente para harmonização das fases do processo de licenciamento de reatores nucleares de pesquisa.

\subsection{Objetivos Específicos}

Os objetivos específicos são:

- Estudar normas e regulamentos nacionais e internacionais aplicáveis ao licenciamento de reatores nucleares de pesquisa;

- Identificar os óbices à compatibilização de normas e regulamentos nacionais e internacionais aplicáveis ao licenciamento de reatores nucleares;

- Identificar os conflitos existentes nos processos de licenciamento em níveis ambiental e nuclear, no país;

- Elaborar uma proposta de estrutura regulatória integrada para o licenciamento de reatores nucleares de pesquisa no Brasil.

\subsection{PREMISSAS}

- Todos os processos de licenciamento de reatores de pesquisa estudados no trabalho correspondem a países membros da AIEA;

- Os processos de licenciamento estudados são permanentes e iniciamse com a avaliação do local, estendendo-se até o descomissionamento, inclusive;

- Os processos de licenciamento devem contemplar aspectos e impactos nucleares e ambientais;

- $\quad$ Os órgãos regulatórios CNEN e IBAMA atuam de forma independente conduzindo e decidindo sobre as questões normativas relacionadas aos processos de licenciamento nuclear e ambiental de reatores nucleares de pesquisa, no país; 
- As normas reguladoras de saúde e segurança no trabalho não estão incluídas na integração da estrutura regulatória, por se tratar de assunto específico da legislação do Ministério do Trabalho e Emprego, no Brasil.

\subsection{Contribuições Originais}

A pesquisa resulta na formulação de uma proposta para aplicação de uma estrutura regulatória integrada contemplando requisitos relacionados à qualidade e meio ambiente com base na normatização atualmente existente e que poderá ser adotada pelos órgãos regulatórios nacionais, contribuindo para a otimização da gestão do processo de licenciamento de reatores de pesquisa nucleares no Brasil.

A pesquisa contribui com uma estrutura inédita, uma vez que não existe processo de licenciamento integrado no Brasil, bem como o país é carente de harmonização dos requisitos normativos e regulatórios existentes nos processos de licenciamento nuclear e ambiental.

\section{As questões da pesquisa são as seguintes:}

- É possível identificar os conflitos existentes nos processos de licenciamento em nível ambiental e nuclear no país e propor soluções?

- Como obter uma estrutura regulatória integrada com abordagem em qualidade e meio ambiente com vistas à harmonização das fases do processo de licenciamento de reatores nucleares de pesquisa no Brasil? 


\section{REVISÃO DA LITERATURA}

\subsection{Reatores de Pesquisas Nucleares no Mundo}

Informações obtidas na base de dados da AIEA denominada de "Research Reactor Data Base" (RRDB) mencionam a existência de 773 reatores de pesquisa distribuídos em 56 países-membros da AIEA $^{1}$, conforme a situação apresentada no TAB.1. Estas instalações compreendem reatores de pesquisa, reatores para treinamento, reatores para testes, protótipos de reatores e instalações críticas.

TABELA 1 - Reatores de Pesquisa - Países Membros da AIEA - Situação Operacional (http://nucleus.iaea.org/RRDB/RR/ReactorSearch.aspx?rf=1, 2014).

\begin{tabular}{|c|c|c|c|}
\hline Situação & $\begin{array}{c}\text { Países } \\
\text { Desenvolvidos }\end{array}$ & $\begin{array}{c}\text { Países em } \\
\text { Desenvolvimento }\end{array}$ & Todos os Países \\
\hline Em operação & 159 & 88 & 247 \\
\hline $\begin{array}{l}\text { Desligados } \\
\text { temporariamente }\end{array}$ & 13 & 6 & 19 \\
\hline Em construção & 3 & 3 & 6 \\
\hline Planejados & 4 & 8 & 12 \\
\hline Desligados & 121 & 22 & 143 \\
\hline Descomissionados & 314 & 24 & 338 \\
\hline Cancelados & 4 & 4 & 8 \\
\hline Total & 618 & 155 & 773 \\
\hline
\end{tabular}

3.2 Reatores de pesquisas nucleares no mundo e seus processos de licenciamento

Para desenvolvimento da pesquisa, foram estudados os processos de licenciamento dos reatores Jules Horowitz Reactor e Osíris (França), HANARO (Coréia do Sul), Maples 1 e 2 (Canadá), OPAL (Austrália), Pallas (Holanda), ETRR-2 Reserach Reator (Egito) e IEA-R1 (Brasil).

\footnotetext{
${ }^{1}$ Informações obtidas em: http://nucleus.iaea.org/RRDB/Reports/Container.aspx?Id=A1. Acesso em: 19/09/2014
} 
O reator Jules Horowitz (JHR) está sendo construído no Centro de Pesquisas de Cadarache, França, que é um dos mais importantes centros de pesquisa e de desenvolvimento tecnológico em energia da Europa ${ }^{2}$. Com uma potência de 100 MW e do tipo piscina, este reator de alto desempenho será utilizado para desenvolver e qualificar combustíveis nucleares e materiais utilizados na indústria nuclear.

Segundo Iracane (2008) a sua operação foi prevista para iniciar em 2014 com uma expectativa operacional de 50 anos e com seu programa experimental direcionado integralmente a testes e desenvolvimento de materiais, não sendo previsto, inicialmente, produção de radioisótopos.

Em 2011, o CEA decidiu desenvolver o projeto Moly e incorporar às atividades do Jules Horowitz Reactor a produção de molibdênio 99 e com isto atender a 25\% da necessidade da Europa, podendo chegar a 50\% se for necessário. Com isto, sua operação está prevista para iniciar em 2016.

Outro reator de pesquisa francês utilizado nesta pesquisa é o OSIRIS, com potência de $70 \mathrm{MW}$, do tipo piscina, cujo principal objetivo é realizar testes e irradiar elementos combustíveis e materiais estruturais empregados em usinas nucleares para geração de energia, além de produzir radioisótopos ${ }^{3}$. O OSIRIS está situado no Centro de Estudo Nucleares de Saclay e sua operação foi iniciada em 1966.

O seu desligamento está previsto para esta década4.

Segundo Berry e Lerouge (1980), na França os reatores de pesquisa seguem o mesmo processo de licenciamento aplicado aos reatores de potência. O licenciamento de instalações nucleares está sob a responsabilidade do Ministério da Indústria e mais particularmente do Serviço Central de Segurança de Instalações Nucleares (SCSIN).

\footnotetext{
2 Informações obtidas em: http://www.cad.cea.fr/index gb.php.

${ }^{3}$ Informações obtidas em: http://www-cadarache.cea.fr/rih/Add-On/osiris gb.pdf. Acesso em 19/09/2014.

${ }^{4}$ Informações obtidas em http://www.french-nuclear-safety.fr/Information/News-releases/Osiris-and-Isisexperimental-reactors-may-continue-to-operate; Acesso em 19/09/2014
} 
A criação do SCSIN dentro do Ministério da Indústria no cenário francês em 1973 atende ao requisito da AIEA em separar claramente o papel do Estado como promotor da energia nuclear e o papel do Ministério da Indústria, como protetor da segurança pública e do meio ambiente (acidentes nucleares por reatividade, consequências por rompimento de tubulações, integridade do combustível nuclear, liberação de radioatividade da contenção, terremotos, choques de aviões entre outros), uma vez que o Ministério da Indústria é responsável pelo estabelecimento e implementação de uma política geral, pela organização e coordenação dos resultados das atividades, pela preparação e aplicação dos regulamentos, e pelos procedimentos de licenciamento para instalações nucleares, inspeções e operações.

O Instituto de Proteção e de Segurança Nuclear (IPSN), criado em 1976 dentro da estrutura do Commissariat à l'Énergie Atomique (CEA), provê o suporte técnico para o SCSIN.

O Departamento de Segurança Nuclear (DSN) deste Instituto realiza as análises para avaliar a segurança dos arranjos apresentados pelos operadores das instalações nucleares, como suporte às solicitações para licenciamento, e também para avaliar o atendimento às condicionantes de segurança prescritas nas licenças emitidas pelo Ministério da Indústria. Um grupo permanente de especialistas nomeado pelo Ministério da Indústria é mantido para estudar problemas técnicos de segurança que se apresentam durante a construção, início da operação e desligamento do reator nuclear. Este grupo é frequentemente consultado pelo SCSIN em todas as questões relacionadas à segurança de todos os reatores, examinando inclusive os relatórios de segurança e os procedimentos operacionais propostos pelos operadores.

O processo de licenciamento francês envolve audiências públicas, conselhos de ministros, diversas avaliações pelo grupo técnico permanente, entre outras ações e é principalmente caracterizado pela emissão de três relatórios de segurança a saber:

- O relatório de segurança preliminar, encaminhado pelo operador ao SCSIN na ocasião em que a licença de construção é requerida e antes do início de qualquer atividade no local em que o empreendimento será construído. Neste relatório estão contidas as intenções, a descrição geral do reator e as regras e 
critérios de segurança que serão seguidas e deve ser liberado por um mecanismo da legislação francesa, denominado "Decreto de Criação", assinado pelo Primeiro Ministro;

- O relatório de segurança provisório que deve ser encaminhado no máximo seis meses antes da primeira carga de combustível no núcleo do reator. Nesta época, o reator está praticamente concluído e o relatório deve mencionar a situação da instalação. Regras gerais provisórias de operação e o programa de testes para início da operação fazem parte deste relatório que está vinculado à "Autorização de Carregamento", assinada pelo Ministro da Indústria; e

- O relatório de segurança final, usualmente apresentado após um ano de operação e que considera toda a experiência adquirida e incorporada, os resultados dos testes, as possíveis modificações da instalação e as regras finais de operação. Este relatório está vinculado à "Autorização de Operação", também assinada pelo Ministro da Indústria.

Outro ponto importante, no processo de licenciamento francês, são as análises e aprovações de modificações nos reatores de pesquisa. Esses reatores, diferentemente de reatores de potência, por serem utilizados para pesquisas, estão constantemente passando por modificações, pois como os programas de pesquisa não podem ser especificados com muita antecedência, os dispositivos experimentais precisam ser alterados periodicamente e, consequentemente, estes reatores são projetados como ferramentas flexíveis. As modificações que envolvem segurança devem ser sempre aprovadas pela autoridade licenciadora.

Para pequenas modificações, o SCSIN delegou esta responsabilidade a uma comissão interna do CEA, denominada de "Comission de Sûreté dês Piles" (CSP), (modificações e alterações que tenham finalidades experimentais). Nestas situações, os responsáveis pelos reatores informam ao presidente da CSP todos os novos experimentos que serão realizados. Todas as autorizações emitidas pela CSP são reportadas ao SCSIN. 
As modificações importantes e significativas são consideradas e tratadas como se fossem um novo processo de licenciamento pelo SCSNI e um novo decreto deve ser formalizado. Caso não seja necessário um novo decreto, as modificações relevantes são incluídas no relatório de segurança que deverá ser encaminhado para avaliação antes do início da realização da modificação. O novo projeto será examinado pelos especialistas em segurança que podem propor recomendações, assim como a realização da modificação, testes de partida e novos procedimentos para operação. O SCSIN deve autorizar a realização de todas as etapas.

Localizado no "Center for Applications of Radioisotopes and Radiation" do Korea Atomic Energy Research Institute (KAERI), em Taejon na Coréia do Sul, o HANARO, "High-flux Advanced Application Reactor", é um reator de pesquisa nuclear, caracterizado como multi-propósito, com potência de $30 \mathrm{MW}$, tipo piscina, cuja operação foi iniciada em 1996. Nele são realizados desenvolvimentos, aplicações, análises e avaliações de tecnologias aplicadas à engenharia de reatores de pesquisa e instalações experimentais associadas. Atualmente, estão sendo realizadas pesquisas para o desenvolvimento de reatores de pesquisas nucleares com alto desempenho, segurança e economia para o mercado globalizado, desenvolvimento e testes em materiais e combustíveis contribuindo fortemente para segurança e economia das plantas nucleares de potência do país, assim como com importantes dados de projeto para o desenvolvimento da tecnologia de reatores da próxima geração. Além disto, o KAERI também está preparando instalações para pesquisa de nêutrons frios, promovendo desta forma, pesquisa de ponta no estabelecimento de métodos analíticos para nano e bioestruturas de materiais.

Vários radioisótopos são fornecidos pelo HANARO e suas tecnologias para aplicação têm sido utilizadas no país e no exterior em várias áreas da medicina, indústria, agricultura e outras ciências ${ }^{5}$.

Na revisão bibliográfica não foram encontradas referências e informações específicas relativas ao processo de licenciamento do HANARO, somente ao

\footnotetext{
5Informações obtidas em: http://www.kaeri.re.kr/ e http://www.nti.org/facilities/9/. Acesso em 20/09/2014
} 
procedimento adotado pela Coréia do Sul para licenciar reatores de potência nucleares, onde Moon (1993) descreve o processo de licenciamento, suas dificuldades e perspectiva futuras.

O órgão regulatório Sul Coreano chama-se "Korea Institute of Nuclear Safety" (KINS) e o processo de licenciamento é realizado em três fases.

$\mathrm{Na}$ primeira fase, são requeridos relatórios do local e do estudo geológico detalhado para solicitação da aprovação do local e da autorização de trabalho limitado antes da obtenção da Permissão para Construção.

Na segunda fase, denominada como "Permissão para Construção" (CP), o KINS analisa a segurança do projeto considerando o atendimento aos códigos e normas relacionadas aos requisitos regulatórios, além do impacto ambiental e medidas para reduzir seus efeitos. Nesta fase, o documento mais importante é o "Relatório Preliminar de Análise de Segurança" (RPAS) e o "Relatório Ambiental" (RA).

Na terceira fase, Licenciamento da Operação, a segurança da planta é avaliada para confirmar a conformidade do projeto com os critérios de aceitação.

Os principais documentos requeridos para emissão da licença de operação são o "Relatório de Análise de Segurança Final" (FSAR), as "Especificações Técnicas" e o "Plano de Emergência Radiológica".

Um sumário do fluxo de atividades do processo de licenciamento adotado pela Coréia do Sul é apresentado nas FIG. 2,3 e 4. Na FIG. 5 é apresentada a estrutura regulatória nuclear da Coréia do Sul.

Moon (1993) descreve que os processos de licenciamento dos reatores de potência coreanos apresentaram uma série de dificuldades, sendo a principal delas a falta de padronização em códigos e normas utilizados nos projetos dos reatores, face à diversidade de tipos de reatores e países fornecedores. Suas consequências foram sentidas com a percepção de várias inconsistências surgidas com procedimentos para realização de testes-hidrostáticos dos sistemas de refrigeração do reator, projetos sísmicos, entre outras. 
Outra dificuldade encontrada foi relativa às diferenças existentes entre os modelos regulatórios dos países fornecedores dos reatores nucleares (Canadá e Estados Unidos da América). Por exemplo, o modelo adotado pela Coréia possui dois estágios com base no regulamento dos Estados Unidos da América. Entretanto, o modelo canadense vigente na ocasião era composto somente por um estágio e tinha como base, a experiência e as consultas técnicas entre o órgão regulatório e a indústria nuclear. 


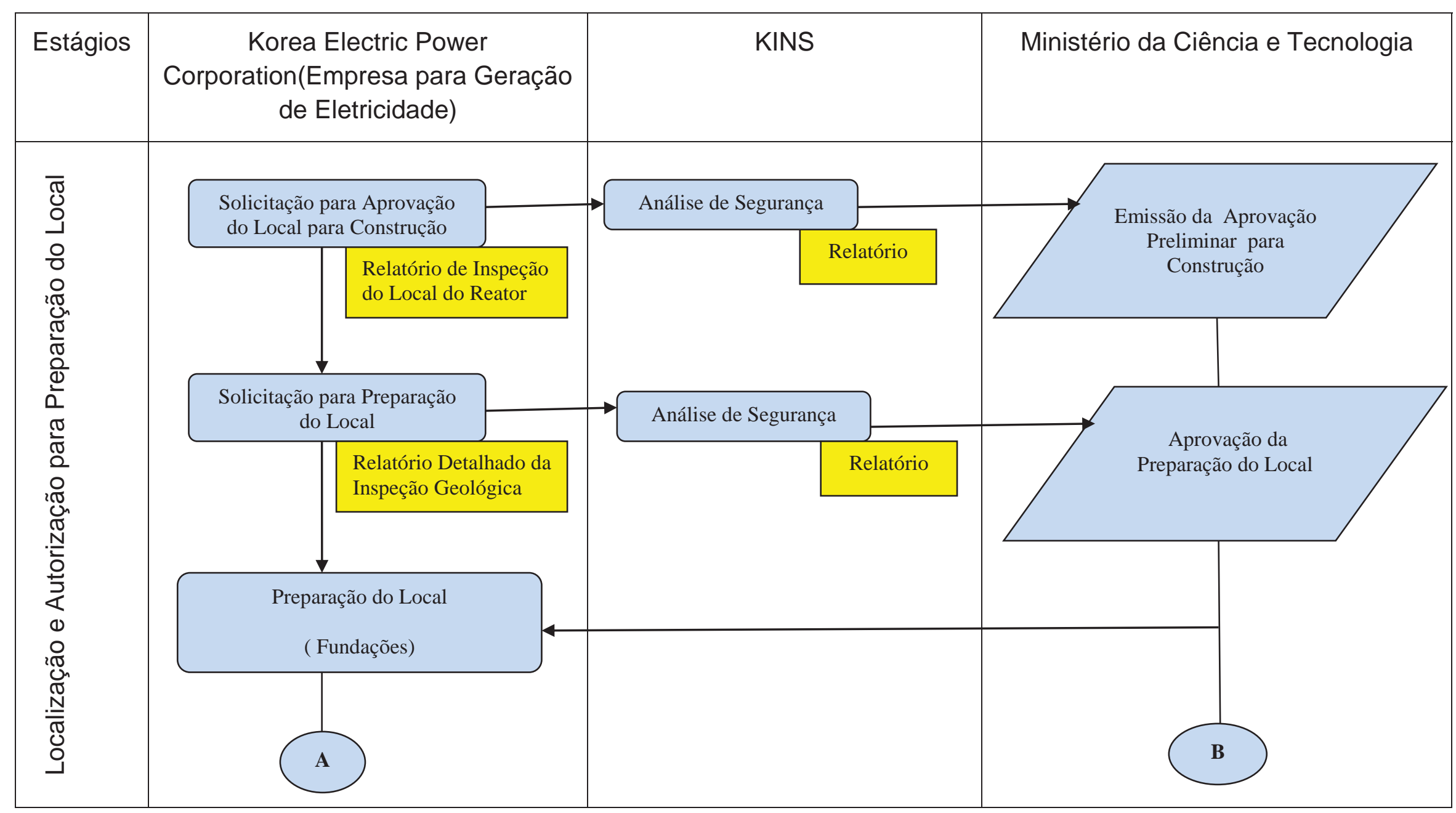

FIGURA 2 - Fluxo de Atividades - Procedimento para Licenciamento de Reatores na Coréia do Sul, aprovação do local para construção ( obtido do to documento: The Licensing Practice on Nuclear Power Plants in Korea, (1993) 


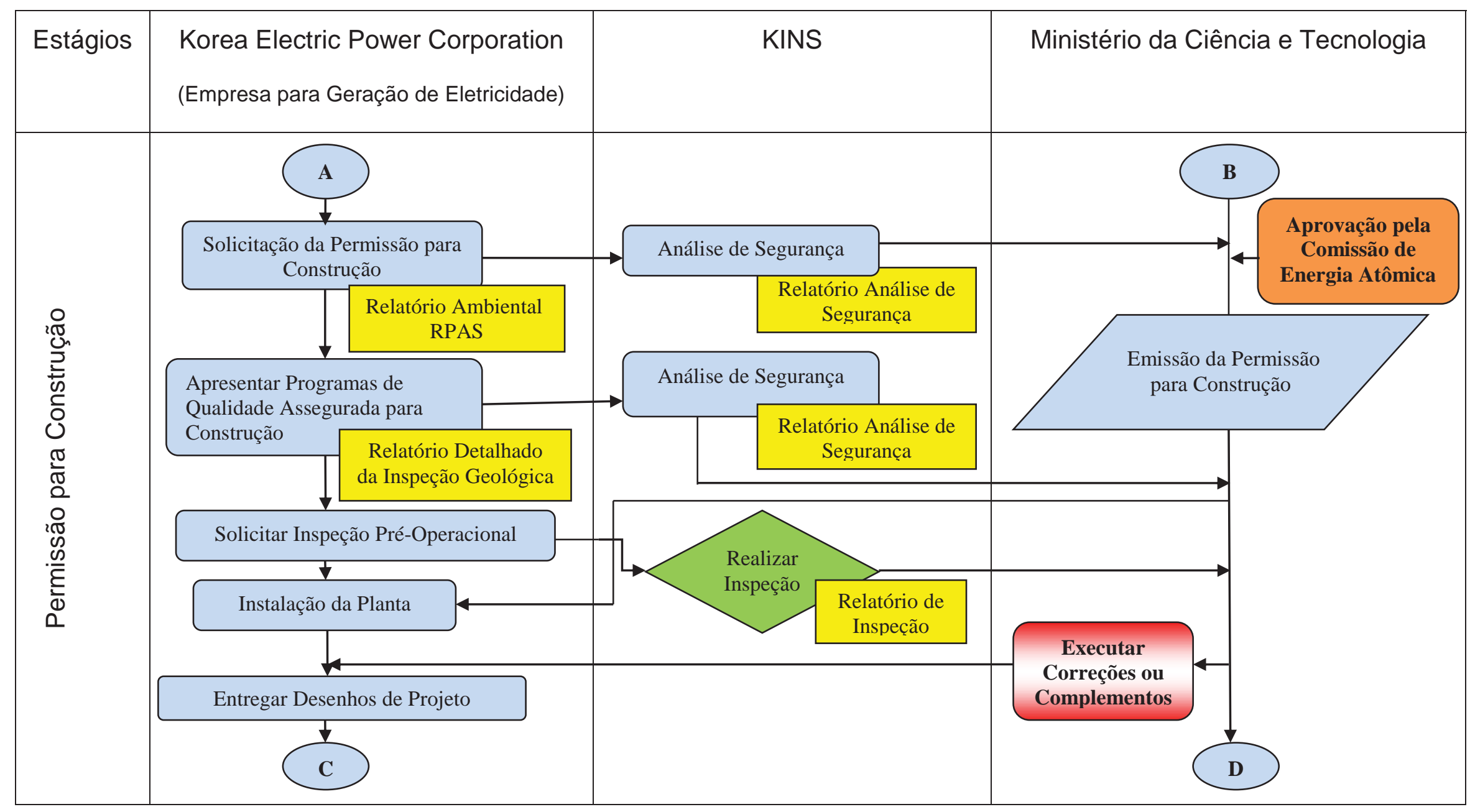

FIGURA 3 - Fluxo de Atividades - Procedimento para Licenciamento de Reatores na Coréia do Sul - Permissão para Construção (obtido do to documento: The Licensing Practice on Nuclear Power Plants in Korea ,(1993) 


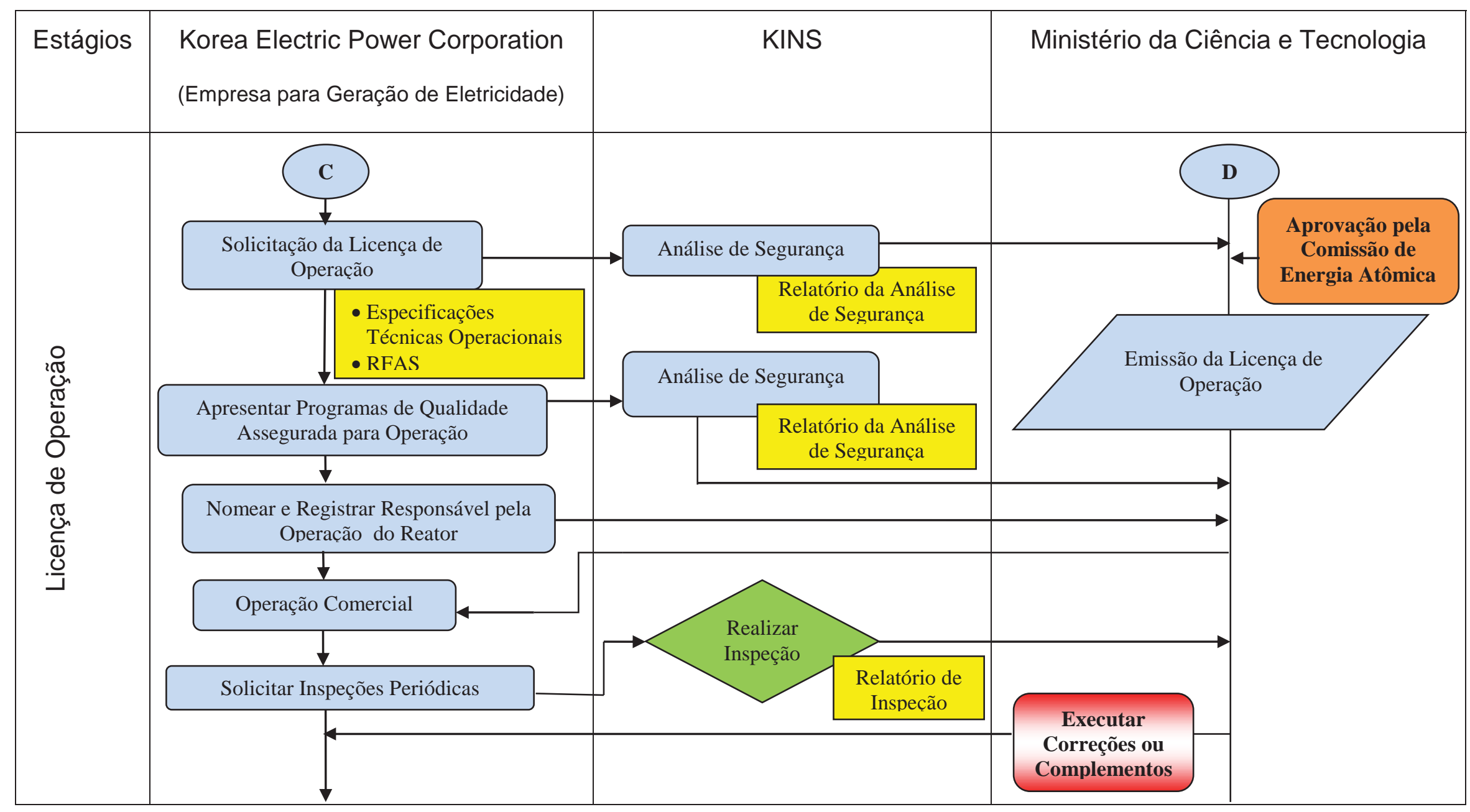

FIGURA 4 - Fluxo de Atividades - Procedimento para Licenciamento de Reatores na Coréia do Sul - Licença de Operação (obtido do to documento: The Licensing Practice on Nuclear Power Plants in Korea, (1993) 


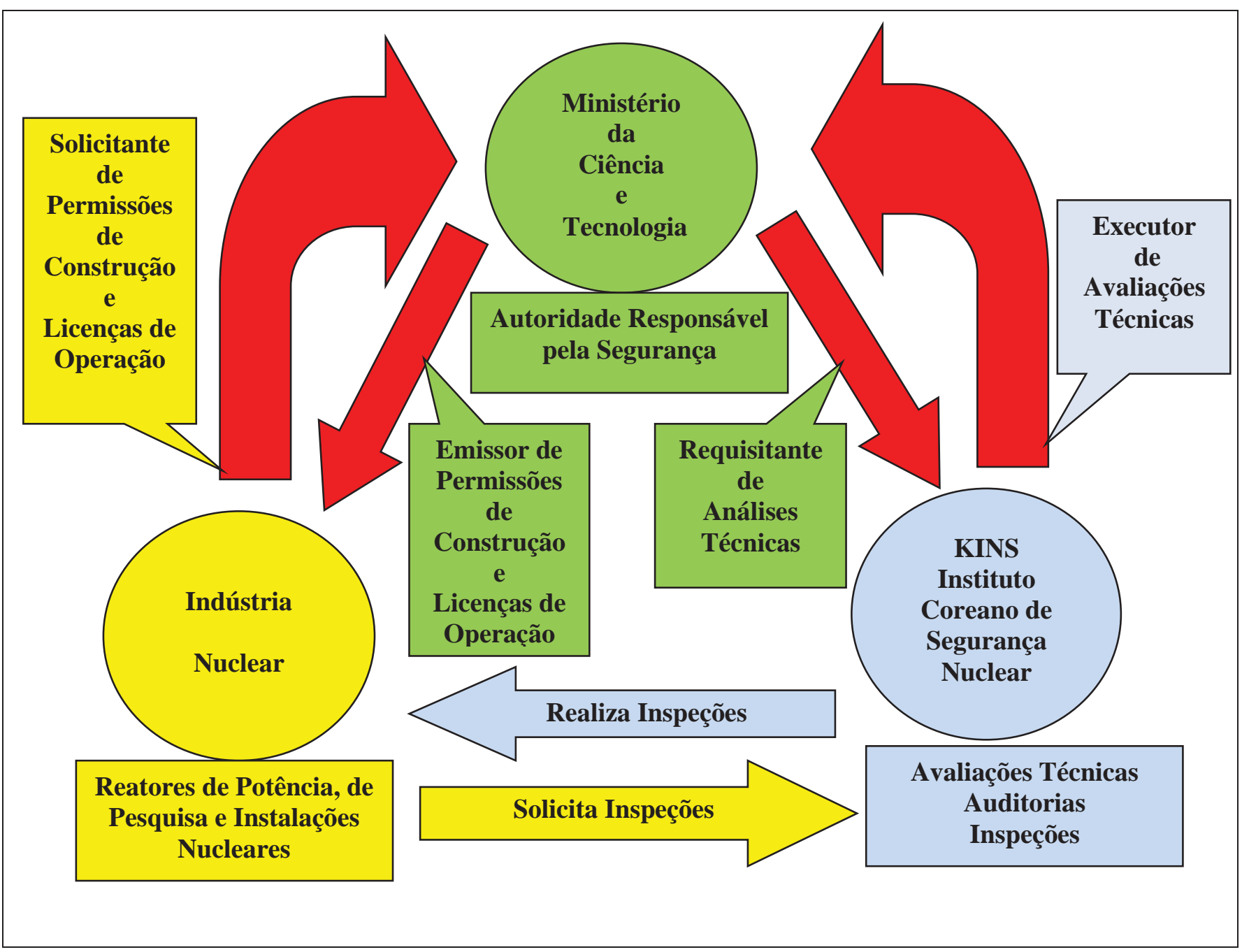

FIGURA 5 - Estrutura regulatória nuclear da Coréia do Sul (obtido do documento: The Licensing Practice on Nuclear Power Plants in Korea, (1993)

No Canadá, o licenciamento de instalações nucleares é realizado pela Comissão de Segurança Nuclear Canadense, a "Canadian Nuclear Safety Commission" (CNSC), uma agência independente que se reporta ao Parlamento Canadense através do Ministério de Recursos Naturais. Esta agência foi estabelecida em 2000 para substituir a "Atomic Energy Control Board" (AECB) 6 .

Atualmente, o procedimento para licenciamento de reatores nucleares está dividido em cinco estágios, a saber:

\footnotetext{
${ }^{6}$ Informações obtidas em:

http<http://www.nuclearsafety.gc.ca/eng/licenseesapplicants/licensingprocess/index.cfm\#a2> . Acesso em: 20/09/2014
} 
- Licença para preparação do local;

- Licença para construção;

- Licença para operação;

- Licença para descomissionamento; e

- Licença para abandono da instalação.

Para a preparação do local, um relatório contendo o tipo de reator, aspectos básicos dos processos e sistemas de segurança, informações sobre o uso do local, densidade populacional (presente e futuro), condições meteorológicas da região, hidrologia, hidrografia, sismologia e hidrografia deve ser apresentado à CNSC.

Também devem ser apresentados os programas ambientais, para determinar as características básicas do local e das áreas do entorno do mesmo, e de qualidade assegurada, para o projeto da instalação nuclear. O requerente deve incluir no relatório os efeitos que serão causados ao meio ambiente e à saúde e segurança das pessoas resultantes das atividades que serão licenciadas, assim como as medidas que serão tomadas para prevenir ou mitigar aqueles efeitos.

A licença de construção somente pode ser solicitada após a aprovação do local pela CNSC. O requerente deve descrever o projeto da instalação nuclear informando como as características físicas e ambientais do local são consideradas no projeto.

O programa de construção e seu planejamento, assim como a descrição das estruturas, dos sistemas e equipamentos da instalação nuclear, seus projetos e as condições de operação propostas.

O programa de qualidade assegurada para o projeto da instalação e um relatório de segurança preliminar demonstrando a adequabilidade do projeto da instalação nuclear devem ser anexados ao requerimento, juntamente com um programa de treinamento para qualificação de operadores e mantenedores da instalação nuclear.

A solicitação da licença de operação deve conter a versão final do relatório de segurança que documenta o final do projeto com a descrição das estruturas, dos sistemas e equipamentos da instalação nuclear, seus projetos e as condições de 
operação, o programa de comissionamento, a qualificação dos operadores e as políticas e procedimentos operacionais, como, por exemplo, procedimentos para manuseio, carregamento do núcleo, transporte de substâncias nucleares e perigosas, comunicação com autoridades externas em caso de acidentes.

Para obter a licença de descomissionamento do reator nuclear, o operador da instalação deve apresentar em seu requerimento, a descrição e o planejamento proposto para descomissionar o reator nuclear, medidas propostas para controlar as substâncias nucleares e substâncias perigosas, informação sobre edifícios, estruturas, sistemas e equipamentos que serão afetados pelo descomissionamento. Outras medidas, relativas principalmente às questões radiológicas e ambientais também são tomadas e poderão ser analisadas durante o desenvolvimento do trabalho.

No requerimento da licença de abandono deverá constar a localização geográfica da instalação, os edifícios, estruturas, componentes e sistemas do reator nuclear e informar os resultados do descomissionamento e do programa de monitoração ambiental. Resíduos de materiais radioativos e produtos perigosos deverão ser informados e tratados, assim como os efeitos ao meio ambiente, saúde e segurança de pessoas

Os reatores nucleares canadenses de pesquisa, caracterizados como multipropósito MAPLE ("Multipurpose Applied Physics Lattice Experimental”) 1 e 2 são do tipo piscina, com potência de $10 \mathrm{MW}$ e foram projetados para produzir radioisótopos em grandes quantidades para diversos países do mundo, inclusive o Brasil. Estão nos laboratórios de Chalk River, na província de Ontário, a 190 km de Ottawa no Canadá?.

Os dois reatores são idênticos, sendo que o MAPLE1 foi construído para produzir ${ }^{125}$ I e o MAPLE 2 para a produção de ${ }^{99} \mathrm{Mo},{ }^{131} \mathrm{I}$ e ${ }^{133} \mathrm{Xe}$, não produzindo ${ }^{125}$ I. Estes reatores foram construídos pela Agência de Energia Atômica do Canadá "Atomic Energy of Canada Limited (AECL)", uma organização federal canadense do tipo "Crown Corporation" operada pela monarquia canadense e responsável pela

\footnotetext{
${ }^{7}$ Informações obtidas em: http://www.aecl.ca/site3.aspx. Acesso em 20/09/2014
} 
gestão da pesquisa e do desenvolvimento da energia nuclear no país. A AECL produz radioisótopos e é o maior fornecedor mundial de Molibdênio - 99 e Cobalto60.

Os MAPLES foram construídos em parceria com a MDS NORDION, uma empresa internacional sediada em Toronto, Ontário, Canadá, do segmento de saúde e ciências da vida, que fornece produtos e serviços para procedimentos diagnósticos e terapêuticos, com o objetivo de substituírem o "Nuclear Research Universal" NRU, que é um reator nuclear canadense em operação por mais de 40 anos. A MDS NORDION tem sido nos últimos anos fornecedora de molibdênio-99, oriundo do NRU, para o IPEN produzir os geradores de tecnécio distribuídos por todo território nacional e que são empregados no diagnóstico de tumores, funções renais, problemas pulmonares e hepáticos.

Segundo Lee et all (1999), a licença de operação dos reatores MAPLE foi aprovada pela "Atomic Energy Control Board" (AECB), entidade precursora da CNSC, em agosto de 1999, ou seja, três anos após o início do projeto pela MDS NORDION.

Os reatores foram licenciados para operar com coeficiente de reatividade negativo, o que significa que a reatividade do núcleo decresceria quando a potência aumentasse.

Em junho de 2003, durante o comissionamento, foi verificado que o reator estava com um coeficiente de reatividade positivo. Exaustivas análises técnicas, consultas e testes, conduzidos inclusive com auxílio da KAERI, entre junho de 2003 e maio de 2008 não resolveram o problema da reatividade. Nem os especialistas da AECL, do Brookhaven National Laboratory, do Idaho National Laboratory e da INVAP, que recentemente concluíram a construção do OPAL, em Sydney na Austrália, conseguiram determinar a causa da reatividade positiva.

Coffin (2008) anunciou oficialmente em maio de 2008 que após inúmeras análises técnicas, análises de custos e de riscos envolvendo a continuidade do 
projeto, conduziram a AECL a descontinuar o desenvolvimento dos MAPLES por causa de problemas técnicos ${ }^{8}$.

Discussões sobre as fases do licenciamento envolvendo normas técnicas, considerações sobre as questões ambientais e nucleares relacionadas ao órgão regulatório canadense poderão ser estudadas e analisadas durante o desenvolvimento deste trabalho.

O OPAL (“Open Pool Australian Light-water Reactor”) é um reator de pesquisa nuclear, multipropósito, com $20 \mathrm{MW}$ de potência, do tipo piscina, e está localizado no Lucas Heights Science and Technology Centre, em Sydney, Austrália. Utilizado para pesquisa de materiais nucleares avançados envolvendo alto fluxo de nêutrons, o reator produz vários radioisótopos para a própria Austrália e para pesquisas nas áreas médica e industrial de países do sudeste da Ásia.

Ele foi projetado e construído para substituir o reator de pesquisa nuclear HIFAR que operou por 49 anos, tendo a criticalidade ocorrido em 26/01/1958 e seu desligamento definitivo em 30/01/2007.

A responsabilidade pela gestão do projeto e construção deste reator foi da ANSTO (Australian Nuclear Science and Technology Organisation), que contratou a empresa argentina INVAP S.E. e os parceiros australianos Jon Holland Construction and Engineering Pty Ltd e Evans Deakin Industries Limited para projetar, construir e comissionar o reator.

Summerfield et all (2003) enfatizam que o processo de licenciamento do OPAL foi desenvolvido de forma integrada ao projeto. Inicialmente, para atender a um requisito regulatório, a ANSTO obteve da ARPANSA uma primeira licença denominada - "Autorização para Preparação do Local"- que consistia na autorização para a ANSTO iniciar as atividades preparar o local sem iniciar qualquer tipo de construção, realizar estudos de solo, água, estabelecer caracterização radiológica do local e seguir todas as condicionantes descritas pela ARPANSA na Autorização para Preparação do Local. Um dos principais documentos que serviram como base técnica para esta licença foi a "Declaração de Impactos Ambientais" ("Environmental

\footnotetext{
${ }^{8}$ Informações obtidas em: http: //www.aecl.ca/NewsRoom/News/Press-2008/080516.htm\#. Acesso em 15/04/2010.
} 
Impacts Statement" - EIS). Outros documentos também tecnicamente importantes e que promoveram o suporte técnico desta licença foram o "Relatório de Análise de Segurança do Local" (considerando as características e as bases de projeto) e o "Relatório de Análise de Acidentes".

A construção do OPAL somente foi iniciada após a autorização da ARPANSA por meio da Autorização para Construção que foi emitida com base no Relatório Preliminar de Análise de Segurança (PSAR), que demonstrava a segurança do projeto da instalação considerando a interação entre os processos, critérios adotados no projeto e demonstração de que as análises de segurança estavam consistentes com o projeto. O PSAR foi elaborado de acordo com as orientações de segurança da AIEA contidas no documento "IAEA Safety Guide SS 35-G1 "Safety Assessment of Research Reactors and Preparation of Safety Analysis Report", 1994.

A autorização para construção foi solicitada pela ANSTO em setembro de 2004 subdividida em cinco seções que continham informações sobre a localização da instalação, dos objetivos do projeto, planos de emergência, relatório com a análise de segurança, condições e limites operacionais, planos e arranjos para o comissionamento a quente.

Em julho de 2006, a ARPANSA concedeu a Autorização para Operação, permitindo o carregamento do núcleo do reator com combustível nuclear, a realização do comissionamento e a operação do OPAL.

$\mathrm{Na}$ Holanda, o "Nuclear Research and Consultancy Group" (NRG) está projetando o reator de pesquisa nuclear holandês PALLAS, com potência de $45 \mathrm{MW}$, que substituirá o também reator de pesquisa "High Flux Reactor (HFR)" para garantir a produção de radioisótopos e a continuidade da pesquisa nuclear no futuro. A vida operacional do HFR se estenderá até 2015 e com isto o NRG espera que haja tempo suficiente para concluir a construção do projeto PALLAS que foi iniciado em 2004 com a cooperação do Centro Médico COVIDIEN (Mallinckrodt Medical) e do Instituto de Energia da Comissão Europeia e da Universidade Técnica Delft. O projeto conceitual do PALLAS está previsto para ser finalizado em 2010, quando será iniciado seu detalhamento, com o objetivo de atingir-se a operação comercial ao fim de 2016. 
Segundo o PALLAS Project Update (2009) ${ }^{9}$ a licença que permitirá o início da construção deverá ser obtida em janeiro de 2012. Não foram encontradas informações sobre o modelo de licenciamento, nuclear e ambiental, assim como as normas técnicas aplicadas ao projeto do PALLLAS.

No Egito, o reator de pesquisa nuclear ETTR-2 é um reator multipropósito utilizado para produção de radioisótopos (I-131, I-125, Cr-51, Ir-192 e Co-60) e teste de materiais.

O reator é do tipo piscina aberta e utiliza elementos combustíveis com enriquecimento inferior a $20 \%$, refrigerado e moderado com água leve e refletido por berílio. A potência do reator é de 22 MW com fluxo de nêutrons maior que 1014 n/cm2.s.

A sua criticalidade ocorreu em novembro de 1997. Como no OPAL, o reator foi construído pela empresa argentina INVAP e segundo E-Kady, (CNSA 7, 2000), o licenciamento do ETTR-2 cumpriu todos os estágios estabelecidos pelo "National Center for Nuclear Safety and Radiation Control "(NCNSRC), que é o órgão criado pela Autoridade em Energia Atômica (AEA) do Egito, responsável por regular e controlar o projeto, pela construção e pela operação de instalações nucleares. Estes estágios são:

- Aprovação do local;

- Permissão para construção;

- Autorização para carregamento de combustível; e

- Licença de operação.

A "Aprovação do Local e a Permissão para Construção" do reator foi obtida após a aprovação do relatório de análise de segurança preliminar apresentado ao NCNSRC com a descrição completa do projeto do reator, dos processos associados, dos sistemas de segurança, dos desenhos e informações sobre as características do local, da análise da interação do reator no local e vice-versa e dos resultados da análise de segurança para demonstrar a consistência do projeto de segurança das estruturas, dos sistemas e dos componentes. Informações sobre

\footnotetext{
${ }^{9}$ Informações obtidas em: http://www.pallasreactor.eu/fileadmin/pallasreactor/user/Pallas project update January 2009.pdf. Acesso em: 20/09/2014.
} 
proteção radiológica, além de um programa preliminar de qualidade assegurada e de um plano de emergência preliminar também foram incluídos neste relatório preliminar de análise de segurança.

A Autorização para Carregamento de Combustível foi obtida após a conclusão da construção e atualização do relatório de análise de segurança, que inclui:

- "As built" do projeto;

- Resultados de testes: dos sistemas de refrigeração (a frio) dos sistemas de desligamento do reator, dos sistemas de proteção radiológica, do processamento e da medição dos canais de neutrons;

- O programa de comissionamento, incluindo procedimentos;

- Limites e condições para operação durante o comissionamento para identificar as barreiras de segurança para a operação; e

- Atualização do plano de emergência.

A licença de operação preliminar foi emitida pela NCNSRC em setembro de 1998 com dois anexos condicionantes, após o reator atingir a máxima potência. Posteriormente, a essa licença foram acrescentadas informações referentes às condições de equilíbrio do núcleo e condições e limites relevantes à segurança, sendo desta forma, considerada como a licença de operação permanente do ETTR2.

No Brasil, o Reator de Pesquisa IEA-R1, localizado no IPEN/CNEN-SP, atingiu a criticalidade em setembro de 1957 e durante os três primeiros anos operou com uma potência de $1 \mathrm{MW}$ passando em seguida para $2 \mathrm{MW}$ e posteriormente para $5 \mathrm{MW}$, com o objetivo de atender à crescente demanda de radioisótopos, além de maior de aumentar sua flexibilidade e capacidade experimental no uso do reator como fonte de nêutrons.

O processo de licenciamento do IEA-R1 não seguiu as regras estabelecidas na norma CNEN-NE-1.04, pois em 1957 a CNEN não havia sido constituída, assim como também não havia regulamentação estabelecida para 
licenciamento de reatores nucleares, quer fossem de pesquisa quer fossem de potência.

Somente em 1972, a CNEN por meio da sua Comissão Deliberativa estabeleceu na Resolução CNEN-06/72, as primeiras normas sobre licenciamento de reatores nucleares de potência, sem considerar até então, o Reator de Pesquisa IEAR1 em operação. Segundo Alvarenga (1989), o primeiro Relatório de Análise de Segurança foi emitido em maio de 1974. Atualmente, o IEA-R1 possui uma Autorização de Operação expedida pela CNEN em setembro de 1997 e renovada em 2006.

Segundo o "Código de Segurança Nuclear para Projeto de Reatores de Pesquisa" (IAEA SS-35-S1, 1992), o controle da segurança nuclear é mantido primariamente por meio de licenças governamentais ou outros instrumentos legais que autorizam o desenvolvimento do projeto e da construção do reator de pesquisa, estabelecendo em cada estágio, quando necessário, condicionantes à organização responsável pela operação.

A AIEA considera o processo de licenciamento de centrais nucleares com reatores de potência como a principal tarefa destes empreendimentos. ${ }^{10}$

Para ilustrar a magnitude desta tarefa, na TAB. 2 são apresentados os tempos médios dos esforços despendidos por órgãos regulatórios de alguns paísesmembros, mensurados em homens-ano.

TABELA 2 - Tempos médios despendidos por Órgãos Regulatórios de diversos países (obtido do documento: Relatório Técnico da AIEA No 153,1974)

\section{País Homens-ano}

França 40

Alemanha

30 a 40 (até 60 para plantas protótipos)

Espanha

25

Inglaterra

40

Estados Unidos

17,3

${ }^{10}$ Informações obtidas em: Organization of Regulatory Activities for Nuclear Reactors. 1a. ED. IAEA, STI/DOC/10/153,Vienna, 1974 
Esses números incluem as atividades de avaliação e inspeção desde a solicitação para emissão da licença de construção até a emissão da licença de operação, mas não há referências se nestas informações estão incluídos os estágios de avaliação do local e de descomissionamento.

Apesar de não terem sido encontradas referências similares para reatores de pesquisa nesta revisão bibliográfica, analogamente pode-se considerar que o processo de licenciamento de reatores de pesquisa possui a mesma relevância atribuída ao processo de licenciamento de reatores de potência, sendo, inclusive, o mesmo procedimento em muitos países-membros.

NA TAB. 3 é apresentada uma matriz comparativa dos estágios que constituem os processos de licenciamento dos sete países-membros analisado até o momento.

À exceção da Holanda, cujas informações sobre seu processo de licenciamento para reatores nucleares de pesquisa não foram encontradas, os processos de licenciamento dos outros países-membros podem variar dependendo de suas legislações e considerações sobre segurança de reatores.

Entretanto, todos os modelos adotados pelos países-membros analisados nesta revisão bibliográfica seguem o modelo da AIEA, que contém cinco estágios: aprovação do local, projeto e construção, comissionamento, operação e descomissionamento, apesar de alguns modelos, como o francês e o sul coreano, apresentarem somente três e dois estágios, respectivamente.

A análise dos processos de licenciamento desses países-membros permitiu observar a existência de um ponto comum e extremamente importante em todos os modelos: o "Relatório de Análise de Segurança" (RAS). Este relatório constitui a principal base de informações para as decisões dos órgãos regulatórios relativas ao licenciamento dos reatores de pesquisa nuclear. O RAS é elaborado preliminarmente para obtenção da licença de construção e, em alguns modelos de licenciamento, sua elaboração preliminar já acontece no estágio de aprovação do local, quando em ambas as situações é denominado de "Relatório Preliminar de Análise de Segurança" (RPAS). 
TABELA 3 - Matriz Comparativa - Fases dos Processos de Licenciamento - AIEA e Países-Membros

\begin{tabular}{|c|c|c|c|c|c|c|c|}
\hline AIEA & França & $\begin{array}{c}\text { Coréia do } \\
\text { Sul }\end{array}$ & Canadá & Austrália & Holanda & Egito & Brasil \\
\hline $\begin{array}{l}\text { Avaliação } \\
\text { do local }\end{array}$ & $\begin{array}{l}\text { Relatório de Segurança } \\
\text { Preliminar }\end{array}$ & $\begin{array}{l}\text { Relatório do } \\
\text { Local e } \\
\text { Estudos } \\
\text { Geológicos }\end{array}$ & $\begin{array}{c}\text { Licença para } \\
\text { Preparação do } \\
\text { local }\end{array}$ & $\begin{array}{l}\text { Autorização } \\
\text { para } \\
\text { Preparação } \\
\text { do Local }\end{array}$ & \multirow{6}{*}{$\begin{array}{c}\text { Não foram } \\
\text { encontradas } \\
\text { informações }\end{array}$} & $\begin{array}{l}\text { Aprovação do } \\
\text { Local }\end{array}$ & Aprovação do Local \\
\hline $\begin{array}{l}\text { Projeto e } \\
\text { Construção }\end{array}$ & Licença de Construção & $\begin{array}{c}\text { Permissão } \\
\text { para } \\
\text { Construção } \\
\text { (RPAS e RA) }\end{array}$ & $\begin{array}{l}\text { Licença para } \\
\text { Construção }\end{array}$ & $\begin{array}{l}\text { Autorização } \\
\text { para } \\
\text { Construção }\end{array}$ & & $\begin{array}{l}\text { Permissão para } \\
\text { Construção } \\
\text { Autorização para } \\
\text { carregamento de } \\
\text { combustível }\end{array}$ & $\begin{array}{l}\text { Licença de Construção } \\
\text { (total ou parcial) } \\
\text { Autorização para } \\
\text { Utilização de Materiais } \\
\text { Nucleares }\end{array}$ \\
\hline \multicolumn{7}{|l|}{$\begin{array}{l}\text { Comissiona } \\
\text { mento }\end{array}$} & \\
\hline Operação & $\begin{array}{c}\text { Autorização de } \\
\text { Carregamento } \\
\text { (Relatório de Segurança } \\
\text { Provisório) } \\
\text { Autorização de Operação } \\
\text { (Relatório de Segurança } \\
\text { Final) }\end{array}$ & $\begin{array}{l}\text { Licença de } \\
\text { Operação }\end{array}$ & $\begin{array}{l}\text { Licença para } \\
\text { Operação }\end{array}$ & $\begin{array}{c}\text { Autorização } \\
\text { para } \\
\text { carregame } \\
\text { nto de } \\
\text { combustíve } \\
\text { I } \\
\text { Autorização } \\
\text { para } \\
\text { Operação } \\
\end{array}$ & & $\begin{array}{l}\text { Licença de } \\
\text { Operação } \\
\text { Preliminar } \\
\text { Licença de } \\
\text { Operação } \\
\text { Permanente }\end{array}$ & $\begin{array}{c}\text { Autorização para } \\
\text { Operação Inicial } \\
\text { Autorização para } \\
\text { Operação Permanente }\end{array}$ \\
\hline \multirow[t]{2}{*}{$\begin{array}{l}\text { Descomissi } \\
\text { onamento }\end{array}$} & & & $\begin{array}{c}\text { Licença para } \\
\text { Descomissiona } \\
\text { mento }\end{array}$ & & & & \\
\hline & & & $\begin{array}{lr}\text { Licença } & \text { para } \\
\text { Abandono } & \text { da } \\
\text { Instalação } & \end{array}$ & & & & \\
\hline
\end{tabular}


O RAS deve conter uma descrição detalhada da localização do reator de pesquisa nuclear, das instalações experimentais e de outras instalações que tenham aspectos significantes de segurança. Deve fornecer uma descrição detalhada dos códigos e normas técnicas aplicadas ao projeto do reator de pesquisa nuclear, dos princípios de segurança e critérios de projeto para proteção do reator, do pessoal de operação, do público em geral e do meio ambiente. Deve ter uma análise de potenciais perigos associados à operação do reator de pesquisa nuclear, uma análise de segurança para possíveis acidentes, uma descrição dos aspectos de segurança incorporados ao projeto para evitar ou minimizar os possíveis acidentes ou, ainda, mitigar suas consequências, quer sejam por meio de considerações no projeto quer sejam por meio de procedimentos operacionais. Os limites e as condições operacionais do reator de pesquisa nuclear descritas no RAS deverão constar na licença de operação. Também deve fornecer detalhes da sobre a condução da operação do empreendimento, do programa de qualidade assegurada estabelecido para o projeto e operação e do plano de emergência do empreendimento. Portanto, como o RAS representa a espinha dorsal de um processo de licenciamento. Ele deve reunir todos os códigos e normas técnicas relacionadas ao projeto, construção, operação e desmobilização dos reatores de pesquisa nucleares, incluindo não somente normas técnicas e regulamentos relativos à qualidade, mas também as normas técnicas e regulamentos envolvendo meio ambiente, saúde e segurança, física e ocupacional, durante todas as fases do empreendimento. 


\section{METODOLOGIA DA PESQUISA}

Neste capítulo serão apresentados os aspectos relacionados à metodologia utilizada considerando os objetivos, o método aplicado e 0 instrumento de pesquisa desenvolvido para exploração do tema da pesquisa.

Segundo Ander-Egg (1978) a pesquisa aplicada é caracterizada pelo seu interesse prático, isto é, que os resultados sejam aplicados ou utilizados, imediatamente, na solução de problemas que ocorrem na realidade.

Hymaan (1967) classifica uma pesquisa como experimental quando a atividade é desenvolvida por meio de levantamentos explicativos, avaliativos e interpretativos, que têm como objetivos a aplicação, a modificação e/ou a mudança de alguma situação ou fenômeno.

Para Lakatos e Marconi (2010), todas as ciências caracterizam-se pela utilização de métodos científicos. Em contrapartida, nem todos os ramos de estudo que empregam estes métodos são ciências. Por essas afirmações podese concluir que a utilização de métodos científicos não é restrita exclusivamente à ciência, mas não há ciência sem o emprego de métodos científicos. Assim, o método é o conjunto das atividades sistemáticas e racionais que, com maior segurança e economia, permite alcançar o objetivo-conhecimentos válidos e verdadeiros- traçando o caminho a ser seguido, detectando erros e auxiliando as decisões do pesquisador.

Com base na proposta deste trabalho, torna-se importante estabelecer a metodologia científica adotada para que objetivo seja alcançado. Para tal, considera-se como Bunge (2004), que o método científico é a teoria da investigação e atinge seus objetivos, de forma científica, quando cumpre as seguintes etapas:

- Descobrimento do problema ou lacuna num conjunto de conhecimentos;

- $\quad$ Colocação precisa do problema;

- Procura de conhecimentos ou instrumentos relevantes ao problema;

- Tentativa de solução do problema com auxílio dos meios identificados; 
- Invenção de novas ideias (teorias ou técnicas) ou produção de novos dados empíricos;

- $\quad$ Obtenção de uma solução;

- Investigação das consequências da solução obtida;

- $\quad$ Prova (comprovação da solução);

- Correção da hipótese, teorias, procedimentos ou dados empregados na solução incorreta (este será, naturalmente, o início de um novo ciclo de investigação).

\subsection{Método da Pesquisa}

A TAB. 5 apresenta a aplicação do método científico e a sua correlação com as etapas desenvolvidas neste trabalho.

O método hipotético-dedutivo desenvolvido por Popper (1975) foi aplicado para desenvolver este trabalho. O início do método acontece com a percepção de uma lacuna nos conhecimentos (problema), passa para uma etapa de formulação de hipóteses (conjecturas) e em seguida para o processo de inferência dedutiva (falseamento), por tentativas de refutação, observação e experimentação. Após estas etapas do processo investigatório atinge-se a fase final e se a hipótese resistir a todos os testes de falseamento pode-se dizer que ela está corroborada, ou seja, a hipótese está validada. Na FIG. 6 está expresso o esquema apresentado por Popper contendo as etapas do método hipotéticodedutivo.

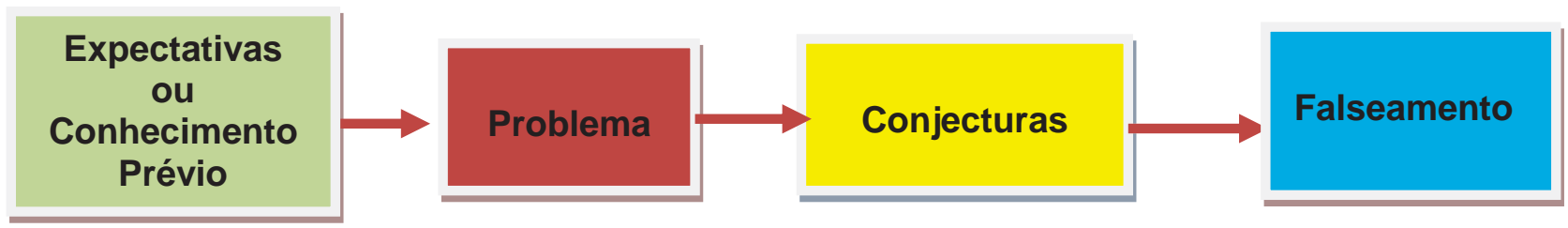

FIGURA 6 - Etapas do Método Hipotético-Dedutivo Segundo Popper (obtido do livro: Metodologia Científica, Lakatos e Marconi, 1983)

A FIG. 7 apresenta um fluxograma simplificado da proposta desenvolvida neste trabalho, aonde o requerente valendo-se da estrutura regulatória integrada prepara somente um processo de licenciamento, reduzindo desta forma o tempo para avaliação da documentação em todas as fases do processo e, consequentemente, o prazo para emissão da licença de operação, 
além de minimizar os possíveis riscos de erros na duplicação de esforços para obtenção das licenças de operação de reatores de pesquisa nuclear.

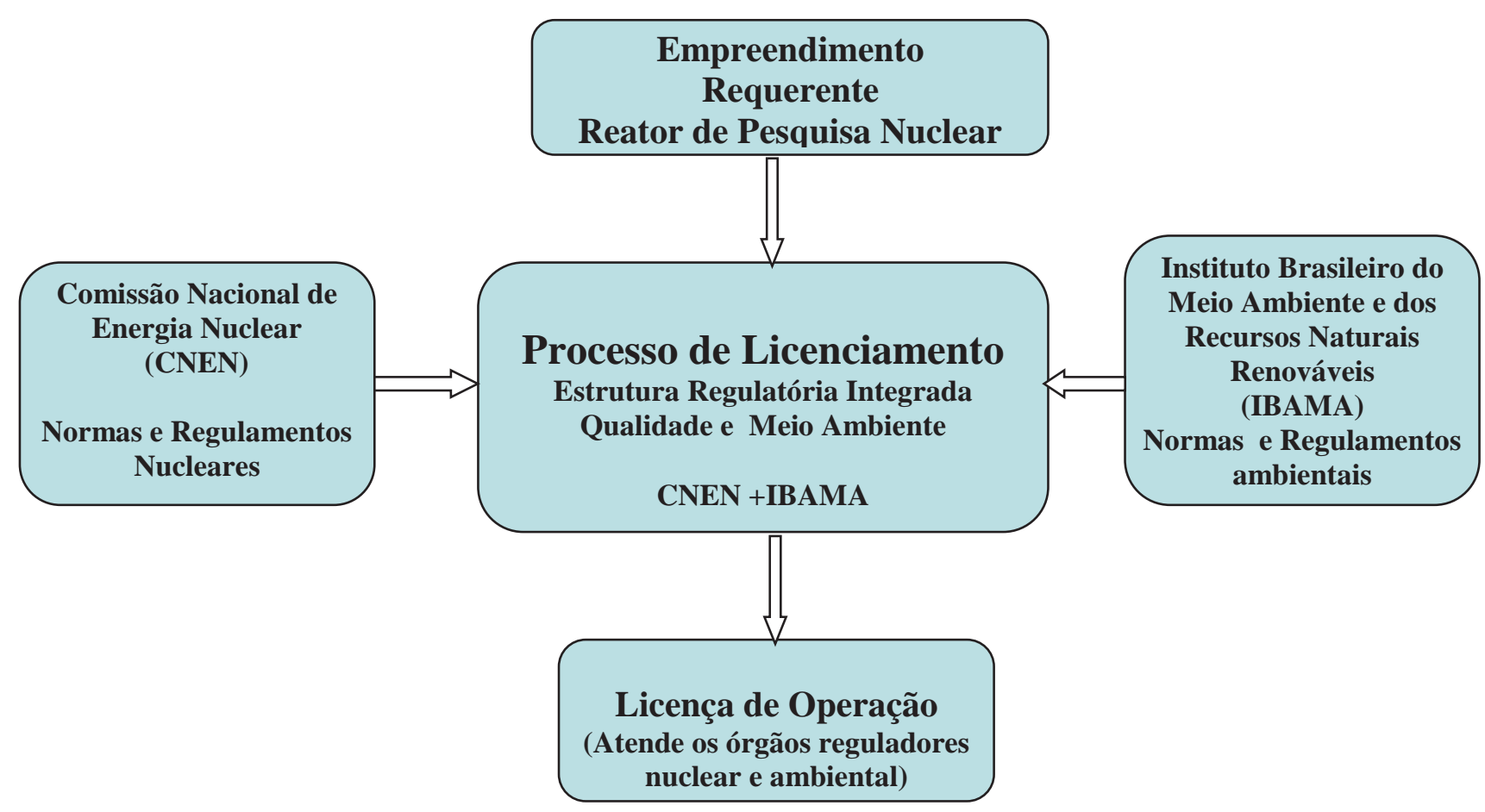

FIGURA 7- Fluxograma simplificado com modelo de licenciamento considerando a estrutura regulatória integrada proposta neste trabalho

\subsection{Detalhamento da Pesquisa}

O fluxograma da FIG. 8 representa as etapas da pesquisa que foram desenvolvidas neste trabalho.

\subsection{Instrumento de Pesquisa}

Para desenvolvimento do instrumento de pesquisa aplicado aos reatores selecionados, foram definidas as oito dimensões mencionadas na TAB.4. As dimensões e subdimensões estão graficamente apresentadas na FIG. 9 e estão relacionadas com os processos de licenciamento nuclear e ambiental, conforme apresentado na TAB. 4, com o detalhamento descrito a seguir. 
TABELA 4 - Correlação das dimensões com as etapas dos processos de licenciamento nuclear e ambiental

\begin{tabular}{|c|c|c|}
\hline Dimensão & Licenciamento Nuclear & Licenciamento Ambiental \\
\hline $\begin{array}{l}\text { Local } \\
\text { (A) }\end{array}$ & Aprovação do Local & Licença Prévia \\
\hline $\begin{array}{c}\text { Aspectos } \\
\text { Regulatórios } \\
\text { (B) }\end{array}$ & - & - \\
\hline $\begin{array}{l}\text { Projeto } \\
\text { (C) }\end{array}$ & $\begin{array}{c}\text { Licença de Construção } \\
\text { (total ou parcial) } \\
\text { Autorização para Utilização } \\
\text { de Materiais Nucleares }\end{array}$ & - \\
\hline $\begin{array}{l}\text { Construção } \\
\text { (D) }\end{array}$ & - & Licença de Instalação \\
\hline $\begin{array}{l}\text { Comissionamento } \\
\text { (E) }\end{array}$ & $\begin{array}{c}\text { Autorização para Operação } \\
\text { Inicial }\end{array}$ & Licença de Operação \\
\hline $\begin{array}{l}\text { Operação } \\
(F)\end{array}$ & $\begin{array}{c}\text { Autorização para Operação } \\
\text { Permanente }\end{array}$ & - \\
\hline $\begin{array}{l}\text { Descomissionamento } \\
\text { (G) }\end{array}$ & - & - \\
\hline $\begin{array}{l}\text { Programa de } \\
\text { Garantia da } \\
\text { Qualidade } \\
\text { (H) }\end{array}$ & $\begin{array}{c}\text { Autorização para Operação } \\
\text { Permanente }\end{array}$ & - \\
\hline
\end{tabular}

A. Aspectos relacionados ao local em que o empreendimento será instalado: diagnóstico ambiental, população local, acesso e rodovias, características físicas do local, consultas a partes interessadas, impactos ambientais/estudos/características físicas, monitoramento ambiental, inventário nuclear;

B. Aspectos regulatórios: legislação ambiental e nuclear, descrição dos experimentos, de outras instalações e atividades significantes 
que provoquem impactos ambientais e riscos à segurança da instalação e da população vizinha, plano de emergência;

C. Projeto: normas e códigos, critérios aplicados a estruturas, sistemas e componentes, classificação de estruturas, sistemas e componentes, limites de projeto, proteção ao meio ambiente;

D. Construção: Infraestrutura para obras, fabricação de componentes, relatório preliminar de análise de segurança, planejamento ambiental e autorizações ambientais;

E. Comissionamento: testes de componentes e sistemas, testes antes do carregamento de combustível, testes de carregamento de combustível, testes de elevação de potência e testes com potência, procedimentos e relatórios;

F. Operação: relatório final de análise de segurança, inspeção final do empreendimento - verificação construção x projeto, programas ambientais, medidas ambientais mitigadoras, inspeção ambiental, relatórios de testes preliminares;

G. Descomissionamento: documentação do reator atualizada, plano de descomissionamento, manuseio, desmontagem, descarte ambiental de resíduos, componentes e equipamentos contaminados;

H. Programa de Garantia da Qualidade: organização, controle de documentos e registros, controle de projeto, controle de aquisições, controle de materiais, controle de processos, inspeções e testes, itens não-conformes, ações corretivas e auditorias;

Com base nas dimensões definidas, foi desenvolvido o instrumento de pesquisa no formato de questionário e que está apresentado no APÊNDICE A. 


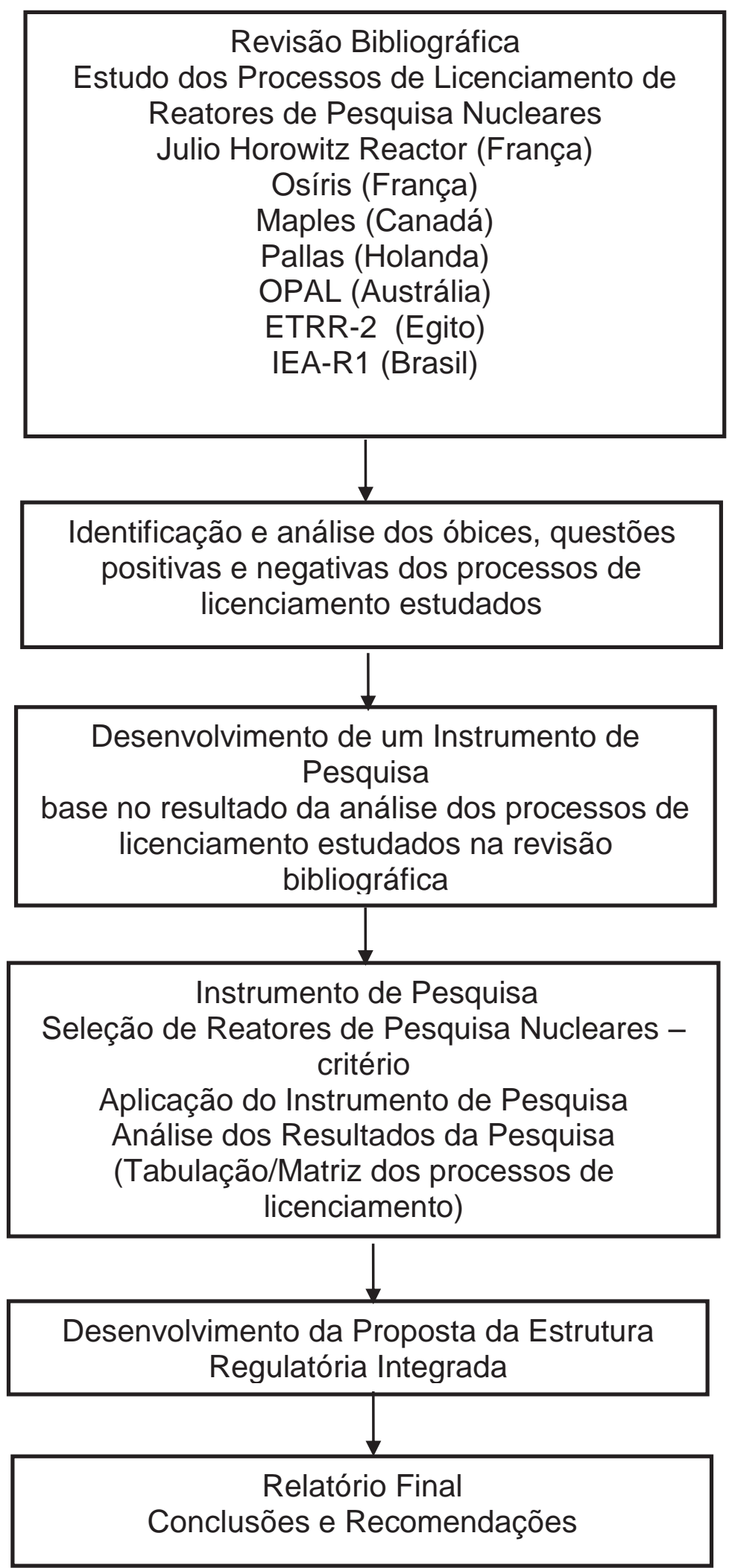

FIGURA 8 - Detalhamento da Pesquisa 


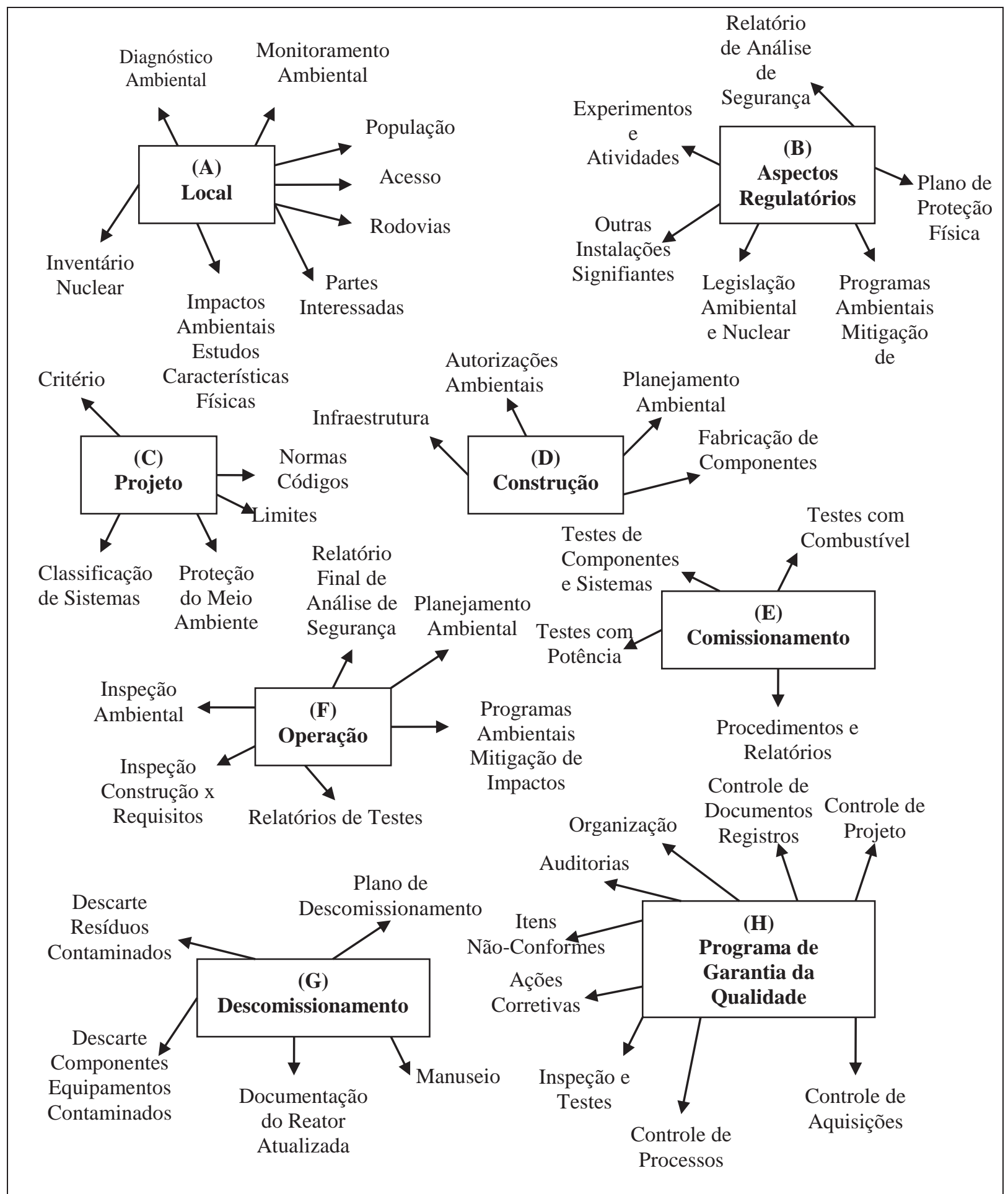

FIGURA 9 - Instrumento de Pesquisa - dimensões e subdimensões 
TABELA 5 - Aplicação do método científico hipotético-dedutivo e científico e a sua correlação com as etapas desenvolvidas neste trabalho

\begin{tabular}{|c|c|c|}
\hline $\begin{array}{c}\text { Método científico } \\
\text { hipotético dedutivo }\end{array}$ & Etapas do desenvolvimento & Descrição das atividades \\
\hline $\begin{array}{l}\text { Fase 1: } \\
\text { Identificação do } \\
\text { problema }\end{array}$ & $\begin{array}{l}\text { Formulação do problema e } \\
\text { determinação dos objetivos }\end{array}$ & $\begin{array}{l}\text { O problema foi identificado nas questões da pesquisa. } \\
\text { Os objetivos, premissas e contribuições originais foram } \\
\text { identificadas e apresentadas no capítulo } 2 \text {. }\end{array}$ \\
\hline $\begin{array}{l}\text { Fase 2: } \\
\text { Com base na } \\
\text { identificação do } \\
\text { problema, estudo de } \\
\text { outros processos de } \\
\text { licenciamento de } \\
\text { reatores de pesquisa } \\
\text { nucleares em países } \\
\text { membros da Agência } \\
\text { Internacional de Energia } \\
\text { Atômica para } \\
\text { desenvolvimento de um } \\
\text { instrumento de pesquisa }\end{array}$ & $\begin{array}{l}\text { Detalhamento da pesquisa; } \\
\text { Seleção da amostra; } \\
\text { Elaboração do instrumento de } \\
\text { pesquisa para coleta de dados; } \\
\text { Coleta de dados }\end{array}$ & $\begin{array}{l}\text { Revisão bibliográfica } \\
\text { Realização da pesquisa bibliográfica em publicações que contêm } \\
\text { informações relativas a processos de licenciamento de reatores } \\
\text { nucleares de pesquisa no mundo. } \\
\text { Foram estudados os processos de licenciamento de nove } \\
\text { reatores de pesquisa em construção ou em operação em países } \\
\text { membros da Agência Internacional de Energia Atômica: Jules } \\
\text { Horowitz Reactor e Osiris (França), Hanaro (Coréia do Sul), } \\
\text { Mapples } 1 \text { e } 2 \text { (Canadá), OPAL (Austrália), Pallas (Holanda), } \\
\text { ETRR-2 (Egito) e IEA R1 (Brasil). } \\
\text { Detalhamento da pesquisa } \\
\text { Expressado no fluxograma da FIG. 8, demonstra o caminho } \\
\text { trilhado na pesquisa para conhecer, a fundo, diversos processos } \\
\text { de licenciamento (fraquezas e forças) nos reatores selecionados } \\
\text { na revisão bibliográfica e, a partir desta experiência, desenvolver } \\
\text { um instrumento de pesquisa, com base em dimensões } \\
\text { previamente definidas para análise. } \\
\text { Desenvolvimento do instrumento de pesquisa } \\
\text { Conforme apresentado no item } 4.3 \text {. }\end{array}$ \\
\hline
\end{tabular}




\begin{tabular}{|c|c|c|}
\hline $\begin{array}{l}\text { Método científico } \\
\text { hipotético dedutivo }\end{array}$ & Etapas do desenvolvimento & Descrição das atividades \\
\hline $\begin{array}{l}\text { Fase 3: } \\
\text { Aspectos do universo da } \\
\text { pesquisa }\end{array}$ & $\begin{array}{l}\text { Resultados, análises e } \\
\text { interpretação dos resultados } \\
\text { obtidos com a aplicação do } \\
\text { instrumento de pesquisa }\end{array}$ & $\begin{array}{l}\text { Nos capítulos } 5 \text { e } 6 \text { são apresentados os resultados e analisados } \\
\text { os dados obtidos e a sua utilização para desenvolvimento da } \\
\text { proposta da estrutura regulatória integrada }\end{array}$ \\
\hline $\begin{array}{l}\text { Fase 4: } \\
\text { Descrição com base nas } \\
\text { observações e } \\
\text { experiências obtidas na } \\
\text { pesquisa }\end{array}$ & $\begin{array}{l}\text { Elaboração da proposta da } \\
\text { estrutura regulatória integrada }\end{array}$ & $\begin{array}{l}\text { Esta etapa contempla a proposta da estrutura regulatória } \\
\text { consistente com as observações e experiências adquiridas nas } \\
\text { fases anteriores da pesquisa }\end{array}$ \\
\hline $\begin{array}{l}\text { Fase 5: } \\
\text { Falseamento: } \\
\text { Avaliação, análises, da } \\
\text { proposição final. }\end{array}$ & Revisão e análise dos objetivos & $\begin{array}{l}\text { Avaliação da proposta da estrutura regulatória e comparação de } \\
\text { suas características com as experiências adquiridas durante a } \\
\text { pesquisa. }\end{array}$ \\
\hline $\begin{array}{l}\text { Fase } 6 \text { : } \\
\text { Com base nos } \\
\text { resultados obtidos, } \\
\text { verificar se as questões } \\
\text { da pesquisa foram } \\
\text { respondidas e os } \\
\text { objetivos foram atingidos } \\
\text { com base nas premissas } \\
\text { estabelecidas para } \\
\text { desenvolvimento da } \\
\text { proposta da estrutura } \\
\text { regulatória integrada }\end{array}$ & Elaboração do relatório final & Redação das conclusões e recomendações da pesquisa \\
\hline
\end{tabular}




\section{RESULTADOS}

Nos capítulos 5 e 6 são apresentados os resultados, análises e discussões dos dados obtidos com a aplicação do questionário de pesquisa. Estes capítulos correspondem à terceira fase da metodologia da pesquisa descrita na TAB. 5 .

Na TAB. 6 encontram-se os dados cadastrais relativos às instalações em que o questionário de pesquisa foi aplicado.

TABELA 6 - Dados informativos das instalações em que o questionário de pesquisa foi aplicado.

\begin{tabular}{|c|c|c|}
\hline Nome & Dados Cadastrais & $\begin{array}{l}\text { Responsável pelas } \\
\text { informações do } \\
\text { questionário de } \\
\text { pesquisa }\end{array}$ \\
\hline $\begin{array}{l}\text { Reator de } \\
\text { Pesquisa } \\
\text { IEA - R1 }\end{array}$ & $\begin{array}{l}\text { Av. Lineu Prestes } 2240 \\
\text { CEP :05508-900, Cidade Universitária } \\
\text { São Paulo, SP } \\
\text { Telefone: (11) } 31338848 \\
\text { wricci@ipen.br } \\
\text { www.ipen.br }\end{array}$ & $\begin{array}{l}\text { Walter Ricci Filho } \\
\text { Supervisor de } \\
\text { Operação do Reator }\end{array}$ \\
\hline $\begin{array}{l}\text { Reator de } \\
\text { Pesquisa } \\
\text { IPEN/MB- } \\
01\end{array}$ & $\begin{array}{l}\text { Av. Lineu Prestes } 2240 \\
\text { CEP :05508-900, Cidade Universitária } \\
\text { São Paulo, SP } \\
\text { Telefone: (11) } 3133 \\
\text { ubitelli@ipen.br } \\
\text { www.ipen.br }\end{array}$ & $\begin{array}{l}\text { Ulisses Bitelli } \\
\text { Rogério Jerez } \\
\text { Responsáveis pela } \\
\text { Operação do Reator }\end{array}$ \\
\hline $\begin{array}{l}\text { Reator de } \\
\text { Pesquisa } \\
\text { Argonauta }\end{array}$ & $\begin{array}{l}\text { Rua Hélio de Almeida } 75 \\
\text { CEP: 21941-972, Ilha do Fundão } \\
\text { Rio de Janeiro, RJ } \\
\text { Telefone: (21) } 21733885 \\
\text { renke@ien.gov.br } \\
\text { www.ien.gov.br }\end{array}$ & $\begin{array}{l}\text { Carlos Alberto Curi } \\
\text { Renke } \\
\text { Responsável - } \\
\text { Operação do Reator }\end{array}$ \\
\hline $\begin{array}{l}\text { Reator de } \\
\text { Pesquisa } \\
\text { Triga IPR- } \\
\text { R1 }\end{array}$ & $\begin{array}{l}\text { Rua Professos Mario Werneck s/n } \\
\text { CEP:30123-970 } \\
\text { Belo Horizonte, Minas Gerais , MG } \\
\text { fmi@cdtn.br } \\
\text { www.cdtn.br }\end{array}$ & $\begin{array}{l}\text { Fausto Maretti Jr. } \\
\text { Responsável - } \\
\text { Operação do Reator }\end{array}$ \\
\hline
\end{tabular}
responderam à pesquisa apesar de inúmeras tentativas.

Na TAB. 7 estão apresentados os resultados da pesquisa considerando as dimensões analisadas, conforme descrito na metodologia adotada na pesquisa e desenvolvida no capítulo 4 deste trabalho. 
TABELA 7 - Resultados da pesquisa de campo

\begin{tabular}{|c|c|c|c|}
\hline Pesquisa - Questionário & Reator IEA -R1 & Reator IPE/MB-01 & Reator de Pesquisa Argonauta \\
\hline \multicolumn{4}{|l|}{ A. Local } \\
\hline $\begin{array}{l}\text { O reator de pesquisa está } \\
\text { localizado em um centro } \\
\text { urbano? }\end{array}$ & Sim & Sim & Sim \\
\hline $\begin{array}{l}\text { Foi realizado um diagnóstico } \\
\text { ambiental do local de instalação } \\
\text { do reator? }\end{array}$ & Não & Sim & Sim \\
\hline $\begin{array}{l}\text { O diagnóstico ambiental está } \\
\text { disponível às partes } \\
\text { interessadas? }\end{array}$ & Não & Capítulo do RAS & $\begin{array}{c}\text { Parte do } 3^{\circ} \text { capítulo do volume } 2 \\
\text { do RAS }\end{array}$ \\
\hline $\begin{array}{l}\text { As partes interessadas foram } \\
\text { consultadas para definição do } \\
\text { local de instalação do reator? }\end{array}$ & Não & Não & Desconhece \\
\hline $\begin{array}{l}\text { Informar como foi realizado o } \\
\text { processo de consulta às partes } \\
\text { interessadas. }\end{array}$ & $\begin{array}{c}\text { Não aplicável } \\
\text { com base na } \\
\text { resposta } \\
\text { anterior }\end{array}$ & $\begin{array}{l}\text { Não aplicável com } \\
\text { base na resposta } \\
\text { anterior }\end{array}$ & $\begin{array}{l}\text { Não aplicável com base na } \\
\text { resposta anterior }\end{array}$ \\
\hline $\begin{array}{l}\text { Foi realizado um estudo dos } \\
\text { impactos ambientais e } \\
\text { características físicas do local } \\
\text { de instalação do reator e } \\
\text { emitido um relatório contendo o } \\
\text { resultado deste estudo? }\end{array}$ & Não & Não & $\begin{array}{c}\text { Parte do } 3^{\circ} \text { capítulo do volume } 2 \\
\text { do RAS }\end{array}$ \\
\hline
\end{tabular}




\begin{tabular}{|c|c|c|c|}
\hline Pesquisa - Questionário & Reator IEA -R1 & Reator IPE/MB-01 & Reator de Pesquisa Argonauta \\
\hline \multicolumn{4}{|l|}{ A. Local } \\
\hline $\begin{array}{l}\text { Que informações relacionadas } \\
\text { à instalação nuclear foram } \\
\text { consideradas para aprovação } \\
\text { do local do reator nuclear } \\
\text { (exemplo: natureza e inventário } \\
\text { dos materiais radioativos)? }\end{array}$ & Não & Não & $\begin{array}{l}\text { Realizado levantamento radiométrico } \\
\text { prévio do solo, da vegetação e do ar } \\
\text { da região para servir de posterior } \\
\text { comparação na eventualidade de } \\
\text { ocorrência de um acidente com fuga } \\
\text { de produtos de fissão para o } \\
\text { ambiente externo ao reator }\end{array}$ \\
\hline $\begin{array}{l}\text { O reator de pesquisa possui um } \\
\text { programa de acompanhamento } \\
\text { e monitoramento ambiental? }\end{array}$ & Sim & Sim & Sim \\
\hline $\begin{array}{l}\text { Os parâmetros monitorados } \\
\text { seguem alguma legislação } \\
\text { ambiental? }\end{array}$ & Não sabe & CNEN & Não \\
\hline $\begin{array}{l}\text { Quais os parâmetros } \\
\text { monitorados? }\end{array}$ & $\begin{array}{l}\text { Radioatividade ar e } \\
\text { água } \\
\text { - } 6 \text { pontos de coleta } \\
\text { subterrânea (lençol } \\
\text { freático) } \\
\text { - } 4 \text { pontos para } \\
\text { coleta de } \\
\text { precipitação } \\
\text { pluviométrica } \\
\text { - } 3 \text { pontos para } \\
\text { monitoração do ar } \\
\text { - 14 pontos para } \\
\text { monitoração do } \\
\text { ambiente utilizando } \\
\text { dosímetros } \\
\text { termoluminescentes }\end{array}$ & $\begin{array}{l}\text { - Água dos } \\
\text { laboratórios, oficina } \\
\text { mecânica e } \\
\text { descontaminação } \\
\text { - Filtros dos } \\
\text { monitores de ar da } \\
\text { célula crítica e } \\
\text { chaminé }\end{array}$ & $\begin{array}{l}\text { Radônio } \\
\text { Radiação gama } \\
\text { Produtos de fissão }\end{array}$ \\
\hline
\end{tabular}




\begin{tabular}{|c|c|c|c|}
\hline Pesquisa - Questionário & Reator IEA -R1 & Reator IPE/MB-01 & Reator de Pesquisa Argonauta \\
\hline \multicolumn{4}{|l|}{ B. Aspectos regulatórios } \\
\hline $\begin{array}{l}\text { Quem é/são o(s) Orgão(s) } \\
\text { Regulador(es) } \\
\text { responsável(eis) pelo processo } \\
\text { de licenciamento do reator de } \\
\text { pesquisa nuclear? }\end{array}$ & CNEN & CNEN & $\begin{array}{l}\text { Coordenação Geral de Reatores e } \\
\text { Ciclo Combustível / CNEN }\end{array}$ \\
\hline $\begin{array}{l}\text { A licença de operação do } \\
\text { reator de pesquisa nuclear é } \\
\text { única e atende a legislação } \\
\text { nuclear e ambiental? }\end{array}$ & $\begin{array}{c}\text { Não. O reator } \\
\text { deverá operar sob a } \\
\text { concessão de } 2 \\
\text { licenças }\end{array}$ & Somente nuclear & $\begin{array}{l}\text { Opera com licença provisória nuclear. } \\
\text { Não possui licença ambiental }\end{array}$ \\
\hline $\begin{array}{l}\text { As atividades e os } \\
\text { experimentos previstos para } \\
\text { serem realizados no reator de } \\
\text { pesquisa estão descritos na(s) } \\
\text { licença(s) de operação? }\end{array}$ & Não & Não & Sim \\
\hline $\begin{array}{l}\text { Outras instalações } \\
\text { significantes que estejam no } \\
\text { mesmo local podem ser } \\
\text { incluídas como parte do reator } \\
\text { nuclear e serem incluídas no } \\
\text { mesmo processo de } \\
\text { licenciamento? }\end{array}$ & Não & Não & Não \\
\hline
\end{tabular}




\begin{tabular}{|c|c|c|c|}
\hline Pesquisa - Questionário & Reator IEA -R1 & Reator IPE/MB-01 & Reator de Pesquisa Argonauta \\
\hline \multicolumn{4}{|l|}{ B. Aspectos regulatórios } \\
\hline $\begin{array}{l}\text { O processo de licenciamento } \\
\text { exige a apresentação de } \\
\text { planos de emergência? }\end{array}$ & Sim & Sim & Sim \\
\hline $\begin{array}{l}\text { O processo de licenciamento } \\
\text { exige a apresentação de um } \\
\text { plano de proteção física? }\end{array}$ & Sim & Sim & Sim \\
\hline $\begin{array}{l}\text { O processo de licenciamento } \\
\text { exige a apresentação de } \\
\text { programas ambientais? }\end{array}$ & Não & Não & Não sabe informar \\
\hline \multicolumn{4}{|l|}{ C. Projeto } \\
\hline $\begin{array}{l}\text { O processo de licenciamento } \\
\text { inclui aspectos relacionados } \\
\text { ao projeto do reator de } \\
\text { pesquisa? Por exemplo: }\end{array}$ & Sim & Sim & Sim \\
\hline Critérios de Projeto & Sim & Sim & Sim \\
\hline Normas e Códigos & Sim & Sim & Sim \\
\hline Limites de Projeto & Sim & Sim & Sim \\
\hline Classificação de Sistemas & Sim & Sim & Sim \\
\hline Proteção ao Meio Ambiente & Sim & Sim & Sim \\
\hline \multicolumn{4}{|l|}{ D. Construção } \\
\hline $\begin{array}{l}\text { O início da construção do } \\
\text { reator de pesquisa precisa } \\
\text { receber aprovação do órgão } \\
\text { regulador? }\end{array}$ & Sim & Sim & Sim \\
\hline
\end{tabular}




\begin{tabular}{|c|c|c|c|}
\hline Pesquisa - Questionário & Reator IEA -R1 & Reator IPE/MB-01 & Reator de Pesquisa Argonauta \\
\hline \multicolumn{4}{|l|}{ D. Construção } \\
\hline $\begin{array}{l}\text { As atividades de } \\
\text { infraestrutura, como } \\
\text { exploração de escavação } \\
\text { preliminar, preparação de } \\
\text { canteiro, vias de acesso, } \\
\text { subestação, linhas de } \\
\text { transmissão, edificações } \\
\text { temporárias podem ser } \\
\text { iniciadas sem autorização ou } \\
\text { licença do órgão regulador? }\end{array}$ & Sim & Não & Não \\
\hline $\begin{array}{l}\text { Para iniciar a fabricação de } \\
\text { componentes da instalação do } \\
\text { reator nuclear é necessário } \\
\text { obter autorização do órgão } \\
\text { regulador? }\end{array}$ & Não sabe informar & Sim & Sim \\
\hline $\begin{array}{l}\text { Quais as autorizações } \\
\text { ambientais são necessárias } \\
\text { para o início da construção do } \\
\text { reator de pesquisa? }\end{array}$ & EIA/RIMA & Não sabe & Não sabe \\
\hline $\begin{array}{l}\text { O início da construção do } \\
\text { reator nuclear exige algum } \\
\text { tipo de planejamento } \\
\text { ambiental? }\end{array}$ & EIA / RIMA & Sim & $\begin{array}{l}\text { Sim. Levantamento habitacional das } \\
\text { circunvizinhanças do reator } \\
\text { Análise radiométrica do solo, } \\
\text { vegetação e ar }\end{array}$ \\
\hline
\end{tabular}




\begin{tabular}{|c|c|c|c|}
\hline Pesquisa - Questionário & Reator IEA -R1 & Reator IPE/MB-01 & Reator de Pesquisa Argonauta \\
\hline \multicolumn{4}{|l|}{ E. Comissionamento } \\
\hline $\begin{array}{l}\text { O programa de } \\
\text { comissionamento do reator } \\
\text { nuclear é um documento } \\
\text { obrigatório e faz parte do } \\
\text { processo de licenciamento? }\end{array}$ & Sim & Sim & Sim \\
\hline $\begin{array}{l}\text { Quais são os estágios do } \\
\text { programa } \\
\text { comissionamento? }\end{array}$ & Não sabe & Não sabe & Não sabe \\
\hline $\begin{array}{l}\text { Há necessidade } \text { de } \\
\text { autorização do órgão } \\
\text { regulador para realizar o } \\
\text { comissionamento do reator de } \\
\text { pesquisa? }\end{array}$ & Sim & Sim & Sim \\
\hline $\begin{array}{l}\text { São gerados procedimentos } \\
\text { para execução e relatórios } \\
\text { contendo os resultados dos } \\
\text { testes de comissionamento? }\end{array}$ & Sim & Sim & Sim \\
\hline F. Operação & & & \\
\hline $\begin{array}{l}\text { Descrever as atividades } \\
\text { ambientais que devem ser } \\
\text { apresentadas ao órgão } \\
\text { regulador para obtenção da } \\
\text { licença de operação ambiental: } \\
\text { planejamento ambiental, } \\
\text { inspeção ambiental, } \\
\text { programas ambientais - } \\
\text { mitigação de impactos }\end{array}$ & Não sabe & Não sabe & Não sabe \\
\hline
\end{tabular}




\begin{tabular}{|c|c|c|c|}
\hline Pesquisa - Questionário & Reator IEA -R1 & Reator IPE/MB-01 & Reator de Pesquisa Argonauta \\
\hline \multicolumn{4}{|l|}{ F. Operação } \\
\hline $\begin{array}{l}\text { Descrever as atividades técnicas } \\
\text { necessárias à obtenção da } \\
\text { licença de operação: inspeção- } \\
\text { construção x requisitos, } \\
\text { relatórios de testes, relatório final } \\
\text { de análise de segurança }\end{array}$ & $\begin{array}{l}\text { Conforme norma } \\
\text { CNEN-NE-1.04 }\end{array}$ & $\begin{array}{l}\text { Relatórios técnicos } \\
\text { descrevendo cada } \\
\text { um dos sistemas } \\
\text { comissionados e } \\
\text { enviados à CNEN }\end{array}$ & $\begin{array}{l}\text { Estabelecimento de um programa } \\
\text { de formação, treinamento e } \\
\text { requalificação para operadores de } \\
\text { reator }\end{array}$ \\
\hline \multicolumn{4}{|l|}{ G. Descomissionamento } \\
\hline $\begin{array}{l}\text { O descomissionamento é } \\
\text { considerado no processo de } \\
\text { licenciamento do reator de } \\
\text { pesquisa? }\end{array}$ & Não & Sim & Não \\
\hline $\begin{array}{l}\text { Exige plano de } \\
\text { descomissionamento? }\end{array}$ & Não sabe & Não sabe & \\
\hline $\begin{array}{l}\text { O descomissionamento exige } \\
\text { uma licença específica para esta } \\
\text { atividade? }\end{array}$ & Não sabe & Não & Sim \\
\hline $\begin{array}{l}\text { Manuseio e transporte de } \\
\text { resíduos }\end{array}$ & Não sabe & Não sabe & Sim \\
\hline $\begin{array}{l}\text { Descarte de resíduos } \\
\text { (equipamentos, componentes, } \\
\text { outros contamidados) }\end{array}$ & Não sabe & Não sabe & Sim \\
\hline
\end{tabular}




\begin{tabular}{|c|c|c|c|}
\hline Pesquisa - Questionário & Reator IEA -R1 & Reator IPE/MB-01 & Reator de Pesquisa Argonauta \\
\hline \multicolumn{4}{|l|}{$\begin{array}{l}\text { H. Programa de Garantia da } \\
\text { Qualidade }\end{array}$} \\
\hline $\begin{array}{l}\text { O programa de garantia da qualidade } \\
\text { do reator nuclear é uma exigência } \\
\text { regulatória? }\end{array}$ & $\operatorname{Sim}$ & Sim & Sim \\
\hline $\begin{array}{l}\text { Está definido pelo órgão regulador } \\
\text { um modelo a ser seguido para } \\
\text { elaborar o programa de garantia da } \\
\text { qualidade? }\end{array}$ & $\begin{array}{c}\text { Sim } \\
\text { CNEN-NN-1.16 }\end{array}$ & $\begin{array}{c}\text { Sim } \\
\text { CNEN-NN-1.16 }\end{array}$ & Não \\
\hline $\begin{array}{l}\text { Descreva o conteúdo do programa } \\
\text { de garantia da qualidade de seu } \\
\text { reator de pesquisa/ }\end{array}$ & Não respondido & CNEN-NN-1.16 & $\begin{array}{c}\text { Rotinas de procedimentos } \\
\text { administrativos } \\
\text { Rotinas de procedimentos } \\
\text { radiológicos } \\
\text { Rotinas de procedimentos de } \\
\text { operação e manutenção do reator }\end{array}$ \\
\hline $\begin{array}{l}\text { Existe algum programa específico } \\
\text { implantado em seu reator nuclear por } \\
\text { exigência regulatória }\end{array}$ & Não & Não & Não \\
\hline
\end{tabular}




\section{ANÁLISE E DISCUSSÃO DOS RESULTADOS}

Nesse capítulo serão apresentadas a análise e discussão dos resultados descritos no capítulo 5 .

\subsection{Análise comparativa entre os modelos regulatórios brasileiro} nuclear e ambiental

O modelo regulatório nuclear brasileiro está estabelecido na norma CNEN-NE-1.04 (2002) que define em seu item 4, o processo geral para concessões de licenças e autorizações a saber:

- Aprovação do local;

- Licença de construção;

- Autorização para utilização de material nuclear;

- Autorização para operação inicial;

- Autorização para operação permanente.

$\mathrm{Na}$ fase de aprovação do local, o requerente da licença deve apresentar à CNEN um relatório denominado como "Relatório Local" contendo as seguintes informações:

- Características gerais de projeto e de operação da instalação;

- Distribuição da população, vias de acesso existentes e propostas, características de utilização das cercanias e distâncias aos centros de população;

- Características físicas do local, incluindo sismologia, meteorologia, geologia e hidrologia;

- $\quad$ Análise preliminar do potencial e influência no meio ambiente em decorrência da construção da instalação e da sua operação normal e em casos de acidentes;

- $\quad$ Programa preliminar de monitoração ambiental pré-operacional;

- $\quad$ Outras informações requeridas por normas relativas à localização de instalações, baixadas pela CNEN.

A construção de uma instalação no local aprovado só poderá ser iniciada após a concessão da licença de construção ou de uma licença parcial de construção.

As informações necessárias para a obtenção da licença de construção devem incluir dados sobre o cronograma preliminar da obra e os prazos, máximo 
e mínimo, estimados para término da construção pretendida, e ser acompanhado dos seguintes documentos:

- $\quad$ Relatório Preliminar de Análise de Segurança (RPAS);

- Plano Preliminar de Proteção Física.

A Autorização para Utilização de Material Nuclear (AUMAN) será concedida caso sejam satisfeitos os seguintes requisitos:

- Que o requerente seja tecnicamente qualificado para utilizar o material nuclear na atividade proposta;

- Que procedimentos de controle de material nuclear, propostos pelo requerente no Plano de Controle, sejam adequados de acordo com a Norma CNEN-NE-2.02 - Controle de Material Nuclear, Equipamento Especificado e Material Especificado;

- Que sejam atendidas condições adicionais que a CNEN, a seu critério exija, a fim de promover melhor controle do material nuclear.

A Autorização para Operação deve ser requerida em duas etapas: a primeira relativa à operação inicial e a segunda à entrada em operação em caráter permanente.

Os documentos necessários para a obtenção da Autorização para Operação Inicial (AOI) são os seguintes:

- $\quad$ Relatório Final de Análise de Segurança (RFAS);

- Plano Final de Proteção Física.

As informações e dados necessários para a obtenção da Autorização para Operação Permanente (AOP) são os seguintes:

- Prazo de operação desejado;

- Dados complementares relativos ao requerente, que não tenham sido incluídos no RFAS, apresentado quando da solicitação da $\mathrm{AOI}$;

- Relatório circunstanciado, descrevendo o desenvolvimento das atividades na fase de $\mathrm{AOI}$;

- Relatório detalhado, apresentando os resultados dos testes realizados durante a operação inicial;

- $\quad$ Programa de Garantia da Qualidade do requerente para a fase de operação em caráter permanente; 
- Demonstração de que a construção da instalação está completamente terminada, de acordo com as condições da licença de construção e da autorização para operação Inicial.

O modelo regulatório ambiental brasileiro para licenciamento ambiental de instalações nucleares foi definido nas Leis 6938/81, Lei No. 7804/89, Lei Complementar No.140/2011 e nas Resoluções CONAMA No. 001/86 e 237/97 e está sob a responsabilidade do IBAMA.

O IBAMA ${ }^{11}$ definiu que o processo de licenciamento ambiental possui três etapas distintas: Licenciamento Prévio, Licenciamento de Instalação e Licenciamento de Operação.

- $\quad$ Licença Prévia (LP) - Deve ser solicitada ao IBAMA na fase de planejamento da implantação, alteração ou ampliação do empreendimento. Essa licença não autoriza a instalação do projeto, e sim aprova a viabilidade ambiental do projeto e autoriza sua localização e concepção tecnológica. Além disso, estabelece as condições a serem consideradas no desenvolvimento do projeto executivo.

- $\quad$ Licença de Instalação (LI) - Autoriza o início da obra ou instalação do empreendimento. O prazo de validade dessa licença é estabelecido pelo cronograma de instalação do projeto ou atividade, não podendo ser superior a 6 (seis) anos. Empreendimentos que impliquem desmatamento depende, também, de "Autorização de Supressão de Vegetação",

- Licença de Operação (LO) - Deve ser solicitada antes de o empreendimento entrar em operação, pois é essa licença que autoriza o início do funcionamento da obra/empreendimento. Sua concessão está condicionada à vistoria a fim de verificar se todas as exigências e detalhes técnicos descritos no projeto aprovado foram desenvolvidos e atendidos ao longo de sua instalação e se estão de acordo com o previsto nas LP e LI. O prazo de validade é estabelecido, não podendo ser inferior a 4 (quatro) anos e superior a 10 (dez) anos. O IBAMA durante o processo de

\footnotetext{
${ }^{11}$ Informações obtidas em: http:// http://www.ibama.gov.br/licenciamento/. Acesso em: 09/109/2014
} 
licenciamento ouve os Órgãos Ambientais (OEMAs) envolvidos no licenciamento e os Órgãos Federais de gestão do Patrimônio Histórico (IPHAN), das Comunidades Indígenas (FUNAI), de Comunidades Quilombolas (Fundação Palmares), de controle de endemias (Secretaria de Vigilância em Saúde do Ministério da Saúde), entre outros. Neste contexto, as prefeituras dos municípios afetados e/ou atravessados pelo empreendimento são ouvidas sobre a questão da adequada inserção do empreendimento frente ao Plano Diretor de Uso e Ocupação do Solo do município.

No processo de licenciamento os estudos ambientais são elaborados pelo empreendedor e entregues ao IBAMA para análise e deferimento. Para cada etapa do licenciamento há estudos específicos a serem elaborados.

Para subsidiar a etapa de LP, sendo o empreendimento de significativo impacto ambiental, o empreendedor encaminha ao IBAMA o "Estudo de Impacto Ambiental e respectivo Relatório de Impacto Ambiental" (EIA/RIMA). Para os demais empreendimentos estudos mais simplificados são requeridos. O EIA é um documento técnico-científico compostos por: Diagnóstico ambiental dos meios físico, biótico e socioeconômico; Análise dos impactos ambientais do projeto e de suas alternativas; Definição das medidas mitigadoras dos impactos negativos e elaboração de medidas mitigadoras dos impactos negativos; e Programas de Acompanhamento e Monitoramento. O RIMA é o documento público que reflete as informações e conclusões do EIA e é apresentado de forma objetiva e adequada a compreensão de toda a população. Nessa etapa são realizadas Audiências Públicas para que a comunidade interessada e/ou afetada pelo empreendimento seja consultada.

Para subsidiar a etapa de LI o empreendedor elabora o Plano Básico Ambiental (PBA) que detalha os programas ambientais necessários para a minimização dos impactos negativos e maximização dos impactos positivos, identificados quando da elaboração do EIA.

Para subsidiar a etapa de LO o empreendedor elabora um conjunto de relatórios descrevendo a implantação dos programas ambientais e medidas mitigadoras previstas nas etapas de LP e LI. 
A TAB. 8 expressa as correspondências entre as etapas que constituem os modelos regulatórios brasileiros nuclear e ambiental e que serão analisadas e discutidas a seguir.

São três as principais correspondências identificadas entre os dois modelos. A primeira correspondência está entre as etapas de Aprovação do Local (nuclear) / Licença Prévia (ambiental). A segunda correspondência foi estabelecida entre as etapas da Licença de Construção (nuclear) e a da Licença de Instalação (ambiental) e a terceira está entre as Autorizações para Operação Inicial e Permanente (nuclear) que, juntas, correspondem à etapa da Licença de Operação (ambiental).

A etapa Autorização para Utilização de Materiais Nucleares (processo de licenciamento nuclear) foi considerada correspondente à etapa da obtenção da Licença de Instalação (processo de licenciamento ambiental), porque a instalação deverá receber o material nuclear antes do início da operação. Segundo a norma CNEN-NE-1.04 (2002), esta autorização deve ser requerida juntamente com a licença de construção.

A etapa de Aprovação do Local (nuclear) inclui questões ambientais que não atendem integralmente às exigências da Licença Prévia (ambiental), como:

- Características físicas do local, incluindo sismologia, meteorologia, geologia e hidrologia;

- A análise preliminar do potencial de influência no meio ambiente em decorrência da construção da instalação e da sua operação normal e em casos de acidentes;

- Programa preliminar de monitoração ambiental pré-operacional.

Enquanto a Licença Prévia (ambiental) requer o Estudo de Impacto Ambiental e respectivo Relatório de Impacto Ambiental (EIA/RIMA).

O EIA é um documento técnico-científico composto por:

- Diagnóstico ambiental dos meios físico, biótico e socioeconômico;

- Análise dos impactos ambientais do projeto e de suas alternativas;

- Definição das medidas mitigadoras dos impactos negativos e elaboração de medidas mitigadoras dos impactos negativos; e 
- $\quad$ Programas de Acompanhamento e Monitoramento.

O RIMA é o documento público que reflete as informações e conclusões do EIA e é apresentado de forma objetiva e adequada a compreensão de toda a população.

Nessa etapa são realizadas Audiências Públicas para que a comunidade interessada e/ou afetada pelo empreendimento seja consultada.

Entende-se que antes de emitir a licença de instalação o IBAMA deverá ouvir os Órgãos Ambientais (OEMAs) envolvidos no licenciamento e os Órgãos Federais de gestão do Patrimônio Histórico (IPHAN), das Comunidades Indígenas (FUNAl), de Comunidades Quilombolas (Fundação Palmares), de controle de endemias (Secretaria de Vigilância em Saúde do Ministério da Saúde), entre outros. Neste contexto, as prefeituras dos municípios afetados e/ou atravessados pelo empreendimento são ouvidas sobre a questão da adequada inserção do empreendimento frente ao Plano Diretor de Uso e Ocupação do Solo do município. A etapa Licença de Construção (nuclear) permite uma situação que desrespeita a sua correspondente na questão ambiental, a Licença de Instalação. Enquanto o início da obra ou instalação do reator de pesquisa nuclear somente pode ser iniciada com a LI ambiental emitida e com prazo máximo de 6 anos, e a obrigatoriedade de apresentar uma "Autorização de Supressão de Vegetação" , para casos em haja desmatamento, e um Plano Básico Ambiental (PBA) detalhando os programas ambientais necessários para a minimização dos impactos negativos e maximização dos impactos positivos, identificados quando da elaboração do EIA, o modelo de licenciamento nuclear permite que atividades como a exploração de escavação preliminar do local e a preparação de infraestruturas para obras de construção, tais como: canteiros, vias de acesso, subestação, linhas de transmissão, edificações temporárias e edificações não destinadas a itens importantes à segurança sejam iniciadas sem a licença de construção nuclear.

A etapa final que permitirá o início da operação possui duas fases no modelo nuclear, Autorização para Operação Inicial e Autorização pra Operação Permanente, e uma fase na sua correspondente ambiental, a Licença de Operação. Temos aqui outro ponto conflitante, pois o reator de pesquisa nuclear não pode iniciar sua operação sem a Licença de Operação ambiental, enquanto pelo processo de licenciamento nuclear, isto é permitido com a Autorização para 
Operação Inicial. Também há diferença nas validades das permissões. A AOP pode ser emitida para um prazo de operação de 40 anos, no máximo, e a LO comprazo de validade entre 4 (não podendo ser inferior) e 10 anos, no máximo. 
TABELA 8 - Matriz de correspondências entre as etapas dos modelos regulatórios brasileiros nuclear e ambiental

\begin{tabular}{|c|c|}
\hline $\begin{array}{c}\text { Norma CNEN-NE-1.04 } \\
\text { - Dez } 2002\end{array}$ & $\begin{array}{c}\text { Lei } 6.938 / 81 \\
\begin{array}{c}\text { Resoluções CONAMA n } \\
\text { Lei Complementar } n^{\circ} 140 / 2011\end{array}\end{array}$ \\
\hline $\begin{array}{l}\text { Aprovação do Local } \\
\text { Apresentar: } \\
\text { 1. Relatório do Local } \\
\text { 1.1) Características gerais do projeto e de operação da } \\
\text { instalação proposta, abrangendo: } \\
\text { 2. } \\
\text { a) Emprego pretendido; } \\
\text { b) Capacidade nominal; } \\
\text { c) Natureza e inventário dos materiais radioativos a serem } \\
\text { contidos: } \\
\text { d) Características especiais que possam ter relação } \\
\text { significativa com a probabilidade ou com as } \\
\text { consequências de uma liberação acidental de material } \\
\text { radioativo; } \\
\text { e) Características de segurança que serão incluídas e os } \\
\text { sistemas de contenção previstos para evitar a liberação de } \\
\text { material radioativo ou de radiação; } \\
\text { f) Adoção, no caso de uma usina nucleoelétrica, de uma } \\
\text { usina de referência tomada como base, de mesma } \\
\text { potência, com as seguintes características: } \\
\text { Estar localizada e licenciada para construção no Brasil ou } \\
\text { em país do principal fornecedor; } \\
\text { Entrar em operação com antecipação suficiente para }\end{array}$ & $\begin{array}{l}\text { Licença Prévia (LP) } \\
\text { - Deve ser solicitada ao IBAMA na fase de planejamento da } \\
\text { implantação, alteração ou ampliação do empreendimento. } \\
\text { - Essa licença não autoriza a instalação do projeto, e sim } \\
\text { aprova a viabilidade ambiental do projeto e autoriza sua } \\
\text { localização e concepção tecnológica. } \\
\text { - Estabelece as condições a serem consideradas no } \\
\text { desenvolvimento do projeto executivo. } \\
\text { Apresentar: } \\
\text { 1) Estudo de Impacto Ambiental e respectivo Relatório de } \\
\text { Impacto Ambiental (EIA/RIMA). O EIA é um documento } \\
\text { técnico-científico compostos por: } \\
\text { a) Diagnóstico ambiental dos meios físico, biótico e } \\
\text { socioeconômico; } \\
\text { b) Análise dos impactos ambientais do projeto e de suas } \\
\text { alternativas; } \\
\text { c) Definição das medidas mitigadoras dos impactos } \\
\text { negativos e elaboração de medidas mitigadoras dos } \\
\text { impactos negativos; e } \\
\text { d) Programas de Acompanhamento e Monitoramento. }\end{array}$ \\
\hline
\end{tabular}




\section{Norma CNEN-NE-1.04 _ Dez 2002}

\section{Aprovação do Local}

permitir o aproveitamento da experiência nos testes préoperacionais e na operação inicial.

1.2) Distribuição da população, vias de acesso existentes e propostas, características de utilização das cercanias e distâncias aos centros de população;

1.3) Características físicas do local, incluindo sismologia, meteorologia, geologia e hidrologia;

1.4) A análise preliminar do potencial de influência no meio ambiente em decorrência da construção da instalação e da sua operação normal e em casos de acidentes;

1.5) Programa preliminar de monitoração ambiental préoperacional;

1.6) Outras informações requeridas por normas relativas à localização de instalações baixadas pela CNEN
Lei 6.938/81

Resoluções CONAMA $n^{\circ}$ 001/86 e $n^{\circ} 237 / 97$ Lei Complementar $n^{\circ}$ 140/2011

\section{Licenca Prévia (LP)}

O RIMA é o documento público que reflete as informações e conclusões do EIA e é apresentado de forma objetiva e adequada a compreensão de toda a população.

2) Nessa etapa são realizadas Audiências Públicas para que a comunidade interessada e/ou afetada pelo empreendimento seja consultada.

Entende-se que antes de emitir a licença de instalação o IBAMA deverá ouvir os Órgãos Ambientais (OEMAs)

envolvidos no licenciamento e os Órgãos Federais de gestão do Patrimônio Histórico (IPHAN), das Comunidades Indígenas (FUNAI), de Comunidades Quilombolas (Fundação Palmares), de controle de endemias (Secretaria de Vigilância em Saúde do Ministério da Saúde), entre outros. Neste contexto, as prefeituras dos municípios afetados e/ou atravessados pelo empreendimento são ouvidas sobre a questão da adequada inserção do empreendimento frente ao Plano Diretor de Uso e Ocupação do Solo do município.

\section{Licença de Construção (total ou parcial)}

A construção de uma instalação no local somente pode ser iniciada após a concessão de uma licença de construção ou de uma licença parcial de construção

\section{Licença de Instalação (LI)}

- Autoriza o início da obra ou instalação do empreendimento;

- O prazo de validade dessa licença é estabelecido pelo cronograma de instalação do projeto ou atividade, não 


\begin{tabular}{|c|c|}
\hline $\begin{array}{c}\text { Norma CNEN-NE-1.04 } \\
- \text { Dez } 2002 \\
\end{array}$ & 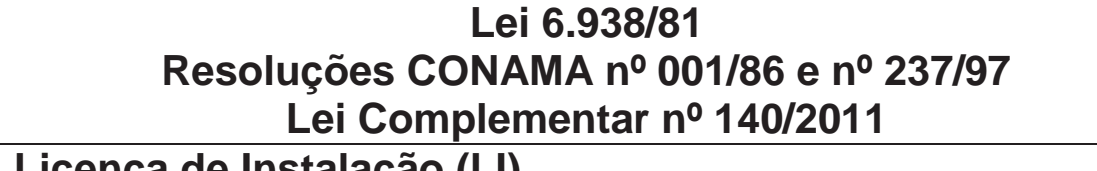 \\
\hline $\begin{array}{l}\text { Licença de Construção (total ou parcial) } \\
\text { Independentemente da licença de construção, as } \\
\text { seguintes atividades podem ser iniciadas no processo de } \\
\text { licenciamento nuclear: } \\
\text { 1) A exploração de escavação preliminar do local e a } \\
\text { preparação de infraestruturas para obras de construção, } \\
\text { tais como: canteiros, vias de acesso, subestação, linhas } \\
\text { de transmissão, edificações temporárias e edificações não } \\
\text { destinadas a itens importantes à segurança; } \\
\text { 2) A fabricação, segundo normas aceitas pela CNEN, de } \\
\text { componentes da instalação. } \\
\text { Apresentar: } \\
\text { 1) Cronograma preliminar da obra e os prazos, máximo e } \\
\text { mínimo, estimados para término da construção pretendida; } \\
\text { 2) Relatório Preliminar de Análise de Segurança (RPAS); } \\
\text { 3) Plano Preliminar de Proteção Física. } \\
\text { Concessão da licença de construção } \\
\text { Três situações podem ocorrer para a concessão da Licença } \\
\text { de Construção pela CNEN: } \\
\text { Situação 1: } \\
\text { Atendimento Integral de todos os requisitos técnicos }\end{array}$ & $\begin{array}{l}\text { Licença de Instalação (LI) } \\
\text { podendo ser superior a } 6 \text { (seis) anos; } \\
\text { - Empreendimentos que impliquem desmatamento } \\
\text { depende, também, de "Autorização de Supressão de } \\
\text { Vegetação". } \\
\text { Apresentar: } \\
\text { 1) O Plano Básico Ambiental (PBA) que detalha os } \\
\text { programas ambientais necessários para a minimização } \\
\text { dos impactos negativos e maximização dos impactos } \\
\text { positivos, identificados quando da elaboração do EIA. }\end{array}$ \\
\hline
\end{tabular}




\section{Norma CNEN-NE-1.04 \\ - Dez 2002}

\section{Licenca de Construcão (total ou parcial)}

a) Estar o requerente qualificado para gerenciar a construção solicitada de acordo com as disposições legais, regulamentares e normativas;

b) Terem sido prestadas todas as informações técnicas exigidas para a completa instrução do processo;

c) Haver garantia aceitável de que, com base nas informações acima, a instalação possa ser construída no local proposto sem risco indevido à saúde e a segurança da população como um todo e ao meio ambiente.

\section{Situação 2:}

Conceder a licença de construção ainda que não seja cumprido integralmente os requisitos da situação 1 desde que:

a) A adoção da usina de referência apresentada no Relatório do Local tenha sido justificada com a identificação de eventuais diferenças quanto à potência, capacidade e características de projeto, com a consequente análise das correspondentes implicações na segurança;

b) Tenha sido descrito no projeto da instalação proposta, incluindo os principais critérios principais de arquitetura e engenharia do projeto e as principais características ou itens nele incorporados para proteção do meio ambiente e da população como um todo;
Lei 6.938/81

Resoluções CONAMA nº 001/86 e n 237/97 Lei Complementar $n^{\circ} 140 / 2011$

\section{Licença de Instalação (LI)}




\section{Norma CNEN-NE-1.04 \\ _ Dez 2002}

\section{Licença de Construção (total ou parcial)}

c) As informações técnicas adicionais, exigíveis para complementar a avaliação de segurança do RPAS, possam razoavelmente ser consideradas posteriormente, no máximo, quando da apresentação do RFAS;

d) Tenham sido descritos os dispositivos e/ou componentes de segurança que exijam pesquisa e desenvolvimento, e tenha sido estabelecido um programa de pesquisa e desenvolvimento objetivando solucionar quaisquer problemas de segurança associados a esses dispositivos e/ou componentes;

e) Haja garantia aceitável de que, com base nas informações acima, os problemas pendentes de segurança da instalação proposta serão satisfatoriamente resolvidos até o término da construção

\section{Situação 3:}

Caso não tenha condições de apresentar todas as informações necessárias à aplicação da situação 2, pode ser requerido à CNEN uma Licença Parcial de Construção, cuja concessão ficará condicionada à avaliação da documentação correspondente constante do RPAS
Lei 6.938/81

Resoluções CONAMA n 001/86 e n 237/97 Lei Complementar $n^{\circ} 140 / 2011$

\section{Licença de Instalação (니)}




\begin{tabular}{|c|c|}
\hline $\begin{array}{c}\text { Norma CNEN-NE-1.04 } \\
\text { - Dez } 2002\end{array}$ & $\begin{array}{c}\text { Lei } 6.938 / 81 \\
\text { Resoluções CONAMA n' 001/86 e } n^{\circ} 237 / 97 \\
\text { Lei Complementar } n^{\circ} 140 / 2011\end{array}$ \\
\hline $\begin{array}{l}\text { Autorização para Utilização de Materiais Nucleares } \\
\text { Será concedida após a comprovação de que a instalação } \\
\text { está pronta para receber o material nuclear e após o } \\
\text { cumprimento pelo requerente das condições exigidas na } \\
\text { norma CNEN-NE-2.02 -"Controle de Material Nuclear, } \\
\text { Equipamento Especificado e Material Especificado }\end{array}$ & Licença de Instalação (니) \\
\hline $\begin{array}{l}\text { Autorização para Operação Inicial (AOI) } \\
\text { Apresentar: } \\
\text { 1) Cronograma preliminar para essa fase de operação com } \\
\text { prazos e datas estimadas para seu início e término; } \\
\text { 2) Relatório Final de Análise de Segurança; } \\
\text { 3) Plano Final de Proteção Física (Norma CNEN_NE-2.01 _ } \\
\text { "Proteção Física de Unidades da Área Nuclear". }\end{array}$ & $\begin{array}{l}\text { Licença de Operação (LO) } \\
\text { Deve ser solicitada antes de o empreendimento entrar em } \\
\text { operação, pois é essa licença que autoriza o início do } \\
\text { funcionamento da obra/empreendimento. } \\
\text { Sua concessão está condicionada à vistoria a fim de verificar } \\
\text { se todas as exigências e detalhes técnicos descritos no } \\
\text { projeto aprovado foram desenvolvidos e atendidos ao longo } \\
\text { de sua instalação e se estão de acordo com o previsto nas } \\
\text { LP e LI. } \\
\text { O prazo de validade é estabelecido, não podendo ser inferior } \\
\text { a } 4 \text { (quatro) anos e superior a } 10 \text { (dez) anos. } \\
\text { Para subsidiar a etapa de LO o empreendedor elabora um } \\
\text { conjunto de relatórios descrevendo a implantação dos } \\
\text { programas ambientais e medidas mitigadoras previstas nas } \\
\text { etapas de LP e LI. }\end{array}$ \\
\hline
\end{tabular}


Norma CNEN-NE-1.04 Dez 2002

\section{Autorização para Operação Permanente}

1) Prazo de operação de 40 anos no máximo;

2) Dados complementares relativos ao requerente, que não tenham sido incluídos no RFAS apresentado na solicitação da AOI;

3) Relatório descrevendo o desenvolvimento das atividades na fase de AOl;

4) Relatório detalhado apresentando os testes realizados durante a operação inicial;

5) Programa de garantia da qualidade do requerente para a fase de operação em caráter permanente;

Demonstração de que a construção da instalação está completamente terminada, de acordo com as condições das licenças de construção, AOI e seus aditamentos.
Lei $6.938 / 81$

Resoluções CONAMA nº 001/86 e n 237/97 Lei Complementar $n^{\circ} 140 / 2011$

\section{Licença de Operação (LO)}




\subsection{Análise dos resultados da pesquisa de campo}

\subsubsection{Reator de Pesquisa IEA-R1}

O reator nuclear de pesquisas IEA-R1 do Instituto de Pesquisas Energéticas e Nucleares está localizado no Campus da Universidade de São Paulo na Cidade Universitária Armando de Salles Oliveira, em São Paulo, SP. O reator é do tipo piscina, projetado pela "Babcok \& Wilcox Company", tendo atingido sua primeira criticalidade em 16 de Setembro de 1957 .

Suas principais utilizações são:

- Produção de radioisótopos para pesquisa, aplicações na medicina, indústria e agricultura;

- Produzir e fornecer nêutrons para experimentos científicos de física, química, engenharia e biologia;

- Treinar pessoas em física de reatores, projetos, desenvolvimento de instrumentação nuclear e segurança de reatores; e

- Treinar e formar operadores de reatores nucleares;

Em seus três primeiros anos de operação, trabalhou com potência de até 1 MW. Entre 1960 e 1995, o regime de operação do reator foi elevado para de 2 MW. A partir de novembro de 1995, o reator teve seu regime de operação alterado novamente, com aumento de potência para 5W.

O Reator de Pesquisa IEA-R1 está localizado em um centro em um centro urbano e iniciou sua operação antes da existência dos modelos regulatórios nucleares e ambiental. Portanto, não foram realizados diagnósticos e estudos de impacto ambiental, consultas a partes interessadas e também não foram avaliadas as características gerais do projeto, levando em consideração a natureza e inventário dos materiais radiativos a serem utilizados. Também não existem dados de monitorações ambientais antes do início de sua operação.

O programa de monitoração ambiental abrange somente parâmetros relacionados ao controle de elementos radiativos, a saber:

a) Avaliação trimestral da radiação direta no meio ambiente (ar) por meio da taxa de exposição medida por dosímetros termoluminescentes (instrumentos utilizados para a medição da dose absorvida durante uma exposição a radiações ionizantes) em 14 pontos; 
b) Análise de emissores gama em amostras de ar (filtros de papel e de carvão ativado) coletadas quinzenalmente em 3 pontos do IPEN utilizando amostrador contínuo;

c) Análise de emissores alfa e beta total em amostras de precipitação pluviométrica coletadas mensalmente em 4 pontos;

d) Análise de emissores alfa e beta total e trício em amostras de água subterrânea coletadas em 8 pontos. Anualmente, são elaborados relatórios, apresentando os resultados das avaliações dos resultados das monitorações realizadas em conformidade com o Plano de Monitoração Ambiental do IPEN e das doses efetivas resultantes da liberação dos efluentes radioativos líquidos e gasosos.

Com relação aos aspectos regulatórios, deve operar com 2 licenças: Autorização de Operação Permanente, emitida pela CNEN, e a Licença de Operação ambiental emitida pelo IBAMA. Possui os planos de emergência, proteção física, relatório de análise de segurança, mas não apresenta programas ambientais para controle e mitigação de impactos ambientais, à exceção daqueles oriundos de eventos radiológicos, conforme descrito anteriormente.

Atividades e experimentos realizados no reator IEA -R1 não estão descritos em suas autorização e licença de operação. Outras instalações significantes no local em que se encontra o reator requerem licenciamentos próprios, não podendo ser incorporadas ao processo do Reator IEA-R1.

Para a dimensão projeto, foi informado que os critérios. Normas, códigos, limites, classificação de sistemas e proteção ao meio ambiente foram seguidos. Entretanto, para o meio ambiente, como já foi constatado anteriormente, o enfoque para o meio ambiente foi restrito às questões nucleares.

Para iniciar a construção, o reator de pesquisa precisa receber a aprovação do órgão regulador, apesar do IEA-R1 não se enquadrar nesta situação, uma vez que foi construído na década de 50, antes da existência de legislação pertinente ao assunto. Por motivo de desconhecimento, não se obteve resposta com relação à necessidade de autorização dos órgãos reguladores para iniciar a fabricação de componentes da instalação, sendo mencionado que para a questão ambiental seria necessário a aprovação do EIA/RIMA e que as atividades de infraestrutura, como exploração de escavação preliminar, preparação de 
canteiro, vias de acesso, subestação, linhas de transmissão, edificações temporárias podem ser iniciadas sem autorização ou licença do órgão regulador.

Quanto à exigência de um planejamento ambiental para iniciar a construção do reator de pesquisa, foi informado que o planejamento está no EIA/RIMA.

O programa de comissionamento é um documento obrigatório e faz parte do processo de licenciamento, sendo necessária a autorização do órgão regulador para a sua realização. Deverão ser gerados procedimentos para execução e relatórios contendo os resultados dos testes de comissionamento, mas foi informado d desconhecimento a respeito dos estágios do programa de comissionamento.

Nesta etapa, foi observado que todas as respostas referiam-se exclusivamente ao processo de licenciamento nuclear.

Para iniciar a operação, foi constatado desconhecimento relacionado às exigências regulatórias ambientais. Quanto à questão nuclear, foi informado que o início da operação poderia acontecer se o reator de pesquisa estiver em conformidade com a norma CNEN-NE-1.04.

O descomissionamento foi uma etapa totalmente desconhecida, desde a sua consideração no processo de licenciamento do reator de pesquisa, como a necessidade de elaboração de um plano de descomissionamento, licenças específicas para realização das atividades, como para manuseio, transporte e descarte de resíduos.

A última dimensão colocada é o programa de garantia da qualidade, que foi respondida como uma exigência regulatória da CNEN e que deve ser elaborado de acordo com o modelo estabelecido na norma CNEN-NN-1.16, mas não sendo respondido sobre o seu conteúdo. Não existe nenhum outro programa específico implantado em seu reator nuclear por exigência regulatória.

\subsubsection{Reator IPEN/MB-01}

O Reator nuclear de pesquisa IPEN/MB-01 está localizado no Instituto de Pesquisas Energéticas e Nucleares, situado no Campus da Cidade Universitária "Armando de Salles Oliveira", bairro do Butantã, centro urbano, na cidade de São Paulo.

É um reator nuclear de pesquisa classificado como potência zero ou Unidade Crítica, do tipo tanque aberto, com potência nominal de operação de 100 
watts, cujo objetivo é a simulação de núcleos e pesquisa das características neutrônicas de reatores moderados a água leve.

Os testes pré-operacionais da Instalação foram concluídos em agosto de 1988, quando então foram iniciados o carregamento do núcleo e os testes de criticalidade. O reator entrou em operação em novembro de 1988, quando ocorreu a primeira criticalidade.

Não foi encontrado o diagnóstico ambiental conforme referido na resposta 1.4 do instrumento de pesquisa, mas sim as informações relativas às características físicas do local (RAS do IPEN/MB-01,2012), conforme requerido na fase de aprovação do local (CNEN-NE-1.04, Item 5.1.3, 2002). Não foram feitas consultas a partes interessadas, assim como também não foi realizado um estudo dos impactos ambientais e também não foram avaliadas as características gerais do projeto, levando em consideração a natureza e inventário dos materiais radiativos a serem utilizados.

O Reator IPEN/MB-01 possui um programa de monitoração ambiental que avalia os níveis de radioatividade aos quais estão expostos os indivíduos do público por meio da análise de amostras de origem atmosférica e aquática, enquanto que a radiação direta no meio ambiente é determinada a partir de medidas com dosímetros termoluminescentes. Existem 4 pontos para coleta de precipitação pluviométrica e 7 pontos para coleta de água no lençol freático, situados perto das instalações nucleares e radioativas do IPEN, na direção preferencial dos ventos. A radiação direta no meio ambiente é determinada a partir da medida com dosímetros termoluminescentes. Atualmente, há 15 dosímetros colocados em pontos críticos ao longo das instalações nucleares e radioativas do IPEN e um ponto para medida de radiação de fundo, situado fora da área de influência do IPEN.

Estas informações foram obtidas no Relatório de Análise de Segurança do Reator Nuclear e divergem das informações registradas no instrumento de pesquisa.

Nos resultados da pesquisa sobre aspectos regulatórios, foi colocado que este reator nuclear de pesquisa deve operar somente com a autorização de operação da CNEN. O reator possui planos de emergência, proteção física, relatório de análise de segurança, mas não apresenta programas ambientais para controle e mitigação de impactos ambientais. 
Atividades e experimentos realizados no reator IPEN/MB-01 não estão descritas em suas autorização e licença de operação. Outras instalações significantes no local em que se encontra o reator requerem licenciamentos próprios, não podendo ser incorporadas ao processo do Reator IPEN/MB-01.

A dimensão projeto foi seguida, com a definição dos critérios de projeto, normas, códigos, limites, classificação de sistemas e proteção ao meio ambiente foram seguidos. Entretanto, para o meio ambiente, como como no reator anterior, foi constatado o enfoque restrito às questões nucleares.

Para iniciar a construção, o reator de pesquisa recebeu aprovação do órgão regulador, assim como para iniciar a fabricação de componentes da instalação. Foi informado que as atividades de infraestrutura, como exploração de escavação preliminar, preparação de canteiro, vias de acesso, subestação, linhas de transmissão, edificações temporárias não podem ser iniciadas sem autorização ou licença do órgão regulador e que o início da construção do reator de pesquisa requer um planejamento ambiental, mas desconhece as autorizações ambientais necessárias para o início da construção do reator nuclear de pesquisa.

Exatamente como no reator nuclear anterior, no Reator IPEN/MB-01 o programa de comissionamento foi um documento obrigatório e fez parte do processo de licenciamento, tendo sido necessário a autorização do órgão regulador para a sua realização. Foram gerados procedimentos para execução e relatórios contendo os resultados dos testes de comissionamento, mas foi informado desconhecimento a respeito dos estágios do programa de comissionamento. Novamente, seguindo o reator nuclear anterior, nesta etapa, foi observado que todas as respostas referiam-se exclusivamente ao processo de licenciamento nuclear.

Para iniciar a operação, também como no IEA -R1, foi constatado desconhecimento relacionado às exigências regulatórias ambientais. Quanto à questão nuclear, foi informado que o início da operação ocorreu após a aprovação da CNEN de "relatórios técnicos descrevendo cada um dos sistemas comissionados".

O descomissionamento foi uma etapa mencionada no instrumento de pesquisa como tendo sido considerada no processo de licenciamento e que não há exigência de licença específica para esta etapa. Há desconhecimento com relação à necessidade de elaboração de um plano de descomissionamento, e da 
obtenção de licenças específicas para realização das atividades, como para manuseio, transporte e descarte de resíduos.

O prorograma de garantia da qualidade é uma exigência regulatória da CNEN e foi elaborado, inclusive em seu conteúdo, seguindo o modelo estabelecido na norma CNEN-NN-1.16. Não existe nenhum outro programa específico implantado em seu reator nuclear por exigência regulatória.

\subsubsection{Reator de Pesquisa Argonauta}

O Reator de Pesquisa Argonauta está localizado na Cidade Universitária, Ilha do Fundão, centro urbano, na cidade do Rio de Janeiro, RJ.

O reator Argonauta entrou em operação em maio de 1965 quando ocorreu a sua primeira criticalidade. E atualmente opera com potência de 500 W, realizando as seguintes atividades:

- Pesquisa e desenvolvimento em física de reatores, técnicas nucleares e segurança nuclear;

- Formação de recursos humanos (treinamento de operadores do reator e teses de mestrado e doutorado);

- Calibração e testes de equipamentos (monitores de área, reativímetros e equipamentos que necessitam de campo neutrônico para serem calibrados);

- Produção de radioisótopos (La-140, Mn-56, Se-75, Br-82) utilizados como traçadores radioativos em pesquisas envolvendo aplicações industriais e estudos do meio ambiente como: otimização de unidades de tratamento de águas residuais urbanas e industriais, estudo da cinética de absorção de selênio em algas e estudo da cinética do manganês em manguezais); ${ }^{12}$

- Análise de elementos em amostras diversas pela ativação de nêutrons térmicos, que permite verificar a presença e/ou quantidade de elementos que constituem amostras geológicas, arqueológicas, ambientais, de alimentos, de plantas, de vegetais e outras.

O diagnóstico ambiental e o estudo dos impactos ambientais e características físicas do local de instalação do reator do reator nuclear de pesquisa encontram-se descritos no 3o capítulo do volume 2 do Relatório de

\footnotetext{
${ }^{12}$ Informações obtidas em: http://www.ien.gov.br/oinstituto/instalacoes/serea/argonauta lindex.htm;
} Acesso em: 27/10/2014 
Análise de Segurança do Reator Argonauta. Porém, não há informações relativas a consultas de partes interessadas na ocasião em que o reator foi construído.

Com relação à aprovação do local em que o reator foi instalado, foi realizado um levantamento radiométrico prévio do solo, da vegetação e do ar da região, para servir de uma posterior comparação, na eventualidade de ocorrência de um acidente com fuga de produtos de fissão para o ambiente externo do reator.

O programa de monitoramento ambiental do reator contempla o acompanhamento de radônio, radiação gama e produtos de fissão, não sendo monitorados parâmetros que sigam a legislação ambiental.

$\mathrm{Na}$ questão regulatória, o reator nuclear de pesquisa opera sob uma licença ainda provisória até o presente que atende à legislação nuclear, mas com relação à legislação ambiental a licença ainda não foi obtida. As atividades e os experimentos previstos para serem realizados no reator de pesquisa estão descritos na licença de operação e outras instalações significantes que estejam no mesmo local do reator deverão obter suas próprias licenças específicas e que considerarão suas peculiaridades. O reator possui planos de emergência, proteção física, relatório de análise de segurança, mas não foi informado se possui programas ambientais para controle e mitigação de impactos ambientais.

$\mathrm{Na}$ dimensão, foi informado que houve definição dos critérios de projeto, normas, códigos, limites, classificação de sistemas e proteção ao meio ambiente.

O início da construção do reator de pesquisa foi aprovado pelo órgão regulador, assim como para iniciar a fabricação de componentes da instalação. Também foi informado, que as atividades de infraestrutura, como exploração de escavação preliminar, preparação de canteiro, vias de acesso, subestação, linhas de transmissão, edificações temporárias não podem ser iniciadas sem autorização ou licença do órgão regulador e que o início da construção do reator de pesquisa requer um planejamento ambiental, mas desconhece as autorizações ambientais necessárias para o início da construção do reator nuclear de pesquisa. No planejamento ambiental para construção do reator Argonauta foram realizados 
o levantamento habitacional das circunvinhanças do reator e análise radiométrica prévia do solo, vegetação e do ar.

O programa de comissionamento foi um documento obrigatório, fez parte do processo de licenciamento e foi necessária a autorização do órgão regulador para a sua realização. Não há informação sobre os estágios do programa de comissionamento.

Foi observado que não há conhecimento sobre as exigências regulatórias ambientais para iniciar a operação do reator de pesquisa nuclear e que para obtenção da licença de operação é necessário que seja estabelecido um programa de formação, treinamento e requalificação para os operadores do reator.

O descomissionamento não faz parte do processo de licenciamento do reator de pesquisa, sendo necessário obter licença específica para esta etapa.

O programa de garantia da qualidade é uma exigência regulatória do órgão regulador e não há um modelo a ser seguido. Os documentos que compõem esse programa são: rotinas de procedimentos administrativos, rotinas de procedimentos radiológicos e rotinas de procedimentos de operação e de manutenção do reator.

Não existe nenhum outro programa específico implantado em seu reator nuclear por exigência regulatória.

\subsection{Análise comparativa do modelo regulatório brasileiro nuclear e} ambiental com o modelo da Agência Internacional de Energia Atômica e os resultados da pesquisa de campo

\subsubsection{O modelo da AIEA}

As referências para esta análise e discussão foram as etapas do modelo da AIEA que se encontra descrito na NS-R-4(2005).

O processo de licenciamento estabelecido pela AIEA pode variar entre os países-membros de Estado, mas, em todos, as principais etapas do processo de licenciamento de reatores de pesquisa nucleares devem incluir a regulamentação para:

- Avaliação do local;

- Projeto e construção;

- Comissionamento; 
- Operação (incluindo utilização e modificações) ${ }^{13}$;

- Descomissionamento.

O processo de licenciamento se inicia com a avaliação do local em que o reator nuclear de pesquisa será instalado e continua até o seu descomissionamento. Enquanto as etapas do licenciamento e procedimentos variam entre os países membros, a primeira etapa obrigatoriamente a ser cumprida para se obter a licença de operação é a avaliação do local. Nesta etapa, para a AIEA, o principal objetivo ao avaliar um local para a instalação de um reator nuclear de pesquisa é a proteção do público e do meio ambiente contra consequências radiológicas normais ou acidentais que podem ocorrer por causa de liberações de materiais radioativos.

$\mathrm{Na}$ avaliação do local para instalação do reator nuclear de pesquisa, os seguintes aspectos devem ser considerados:

- Efeitos de eventos externos que podem ocorrer na região da instalação (os eventos podem ser naturais ou induzidos por seres humanos);

- As características do local da instalação e seu meio ambiente que poderão atingir o público se houver liberação de material radioativo;

- A densidade da população, sua distribuição e outras características relevantes do local para possíveis medidas de emergência e a necessidade de avaliar os riscos para indivíduos e população;

- Alguma outra instalação nuclear no local;

- Capacidade local de fornecimento de água para resfriamento de sistemas do reator nuclear de pesquisa em caso de acidentes ("ultimate heat sink").

O resultado da avaliação do local deverá ser documentado e apresentado com detalhes que permitam uma análise independente do órgão regulatório do país. Isto pode constituir a primeira parte do relatório de análise de segurança para o reator nuclear de pesquisa.

Bases do projeto, códigos, normas técnicas, classificação de estruturas, análise de acidentes, eventos internos e externos, definição de limites de projeto, testes de funcionamento, inspeções, projeto do comissionamento e descomissionamento, requisitos específicos relacionados ao projeto nuclear

${ }^{13}$ Segundo a NS-R-4(2005), embora a utilização e modificação em reatores de pesquisa nuclear sejam atividades que normalmente estão incluídas na operação, elas podem ser consideradas como estágios separados no processo de licenciamento. 
(núcleo do reator, combustível, reatividade, sistema de desligamento, sistemas de emergência, sistemas de proteção à radiação), instrumentação, sistemas elétricos e auxiliares, são aspectos que compõem esta etapa de projeto.

A etapa da operação deve estabelecer uma gestão adequada ao reator nuclear de pesquisa. A estrutura de responsabilidades para operação do reator deve estar definida e preparar as especificações, procedimentos, relatórios periódicos, programas detalhados para realizar experimentos, realizar inspeções. Testes e manutenções periódicas.

A estrutura da AIEA inclui o comissionamento como uma das etapas do processo de licenciamento de reatores de pesquisa nuclear. Assim, é fundamental o estabelecimento de um programa de comissionamento para realização de testes nos sistemas e componentes do reator de pesquisa nuclear após a construção ou modificação, para demonstrar que estes atendem aos objetivos do projeto e estão de acordo com seus critérios de desempenho. Os dispositivos experimentais devem ter especial atenção durante o comissionamento do reator de pesquisa nuclear.

A última etapa do processo de licenciamento estabelecido pela AIEA é o descomissionamento. Um plano de descomissionamento deverá ser preparado para garantir a segurança da atividade. A documentação do reator deve ser mantida atualizada, assim como informações e experiências com manuseio de materiais e componentes contaminados e irradiados de estruturas e sistemas anteriormente realizados durante atividades de manutenção ou modificações no reator de pesquisa nuclear, devem ser registrados para facilitar o planejamento do descomissionamento.

Ainda dentro do processo de licenciamento de reatores nucleares de pesquisa, a AIEA utiliza um documento denominado como relatório de análise de segurança, que deve ser preparado pela organização responsável pela operação da instalação, que deve conter a justificativa para seleção do local e projeto da instalação, além de ser a base para uma operação segura do reator nuclear de pesquisa. Este relatório deve descrever detalhadamente o local em que o reator nuclear de pesquisa será instalado, os dispositivos experimentais e outras instalações significantes que serão operadas ou que serão parte do reator nuclear de pesquisa. O relatório também deve descrever os princípios de segurança e critérios de projeto para proteção da instalação, das equipes envolvidas em sua 
operação, do público e do meio ambiente. Deve conter a análise dos riscos potenciais associados à operação, análise de acidentes, mitigação de suas consequências com base no projeto ou procedimentos operacionais.

\subsubsection{Análise e discussão entre os modelos da AIEA - CNEN- Resultados da pesquisa}

Na TAB. 9 é apresentada a comparação entre o modelo da AIEA com os modelos regulatórios brasileiros, nuclear e ambiental, e os resultados da pesquisa de campo, que foram realizados nos três reatores nucleares de pesquisa.

Na etapa relativa à aprovação do local descrito pela AIEA no NS-R-4 ("Safety of Research Reactors") não há a recomendação para realização de um diagnóstico ambiental completo considerando todos os aspectos nucleares ou não, que possam causar impactos ambientas na região. A recomendação da AIEA está direcionada para os cinco aspectos descritos anteriormente e para as características ambientais da região que podem ser afetadas por potenciais consequências radiológicas oriundas de liberação radiativa do reator nuclear de pesquisa durante a sua operação ou em condições de acidente. Não menciona a necessidade de consultas a partes interessadas e faz referência uma monitoração de riscos, denominados "Riscos Induzidos por Pessoas Externas" como, impactos de aviões, explosões químicas, outros eventos importantes induzidos por pessoas externas, dispersão atmosférica de material radioativo, dispersão de material radioativo na água e no solo, uso da água e da terra na região, radioatividade ambiente. As características naturais e riscos induzidos por pessoas externas assim como o controle demográfico, meteorológico e hidrológico relevantes para o reator de pesquisa nuclear devem ser monitorados desde a construção até o descomissionamento da instalação.

A CNEN nesta etapa exige a apresentação do "Relatório do Local", que está alinhado com as recomendações da AIEA e acrescenta a necessidade da elaboração de um programa preliminar de monitoração pré-operacional, mas sem dizer os parâmetros e características que devem ser monitoradas, ou mesmo a base utilizada para definição dos parâmetros e/ou características a serem monitoradas. Também não há a recomendação para realização de um diagnóstico ambiental completo considerando todos os aspectos ambientais, nucleares e não- 
nucleares, que possam causar impactos ambientas na região. Não há recomendação para que partes interessadas sejam consultadas.

As exigências do IBAMA são muito mais abrangentes e completas para aprovação do local, que possui a denominação própria de licença prévia. Elas compreendem obrigatoriamente estudo de impacto ambiental contendo os aspectos e impactos ambientais de origem nuclear e convencional. Da mesma forma, as consultas a partes interessadas envolvem órgãos ambientais, comunidades e instituições da região ou não, que podem ser afetadas pela instalação do reator de pesquisa nuclear.

O resultado da pesquisa demonstrou que o diagnóstico ambiental e o estudo de impactos ambientais foram realizados somente para os aspectos nucleares e as partes interessadas não foram consultadas. Os reatores IEA R1 e o Argonauta iniciaram suas atividades em 1957 e 1965, respectivamente ${ }^{14}$, sendo, portanto, precursores de toda a legislação ambiental que existe atualmente.

O Reator IPEN/MB-01 iniciou suas atividades em $1988^{14}$ em um momento em que a legislação relacionada ao processo de licenciamento para reatores de pesquisa nucleares estava em transição. A operação foi autorizada por meio das resoluções CNEN 23 e 25 a autorização para a sua operação inicial ${ }^{14}$.

As monitorações ambientais dos três reatores nucleares de pesquisa são realizadas para acompanhamento dos níveis de radioatividade atmosférica, aquática e diretamente no meio ambiente.

Com relação ao projeto e construção, o modelo da AIEA foi seguido pelos três reatores de pesquisa nucleares nos temas critérios de projeto, normas e códigos, limites de projeto e classificação de sistemas, que não fazem parte das exigências requeridas pelo IBAMA para o licenciamento ambiental.

A proteção ao meio ambiente do modelo da AIEA foi seguida pelos três reatores de pesquisa nucleares conforme foi constatado no resultado da pesquisa, porém precisam ser complementados com a consideração dos aspectos ambientais convencionais.

\footnotetext{
${ }^{14}$ Informações obtidas em: https://www.ipen.br/sitio/?idm=251; http://www.ien.gov.br/oinstituto/instalacoes/serea/argonauta/historico 01.htm; https://www.ipen.br/sitio/?idm=248. Acesso em 17/10/2014.
} 
No modelo CNEN não há uma etapa específica para tratar do projeto, estando este incluído dentro do Relatório Preliminar de Análise de Segurança (RPAS), que está inserido como um dos requisitos regulatórios da etapa denominada licença de construção. A construção de um reator de pesquisas nuclear somente pode ser iniciada após a concessão de uma licença de construção ou uma licença parcial de construção. Para receber a licença de construção, a CNEN exige que o reator de pesquisa nuclear requerente esteja qualificado para gerenciar a construção de acordo com as disposições legais, regulamentares e normativas. Deve demonstrar que todas as informações técnicas exigidas pela CNEN foram atendidas e garantir que a instalação possa ser construída no local proposto sem risco à saúde, à segurança da população e ao meio ambiente. Dentro desta orientação, a CNEN pode conceder a licença de construção mesmo que não tenha sido cumprido integralmente o compromisso de demonstrar o atendimento à transmissão de todas as informações técnicas exigidas pela CNEN.

Nesta etapa, independentemente da licença de construção, o modelo CNEN permite que as seguintes atividades possam ser iniciadas:

- A exploração de escavação preliminar do local e a preparação de infraestruturas para obras de construção, tais como: canteiros, vias de acesso, subestação, linhas de transmissão, edificações temporárias e edificações não destinadas a itens importantes à segurança;

- A fabricação, segundo normas aceitas pela CNEN, de componentes da instalação.

Ainda nesta etapa, o reator de pesquisa nuclear deverá requerer a "Autorização para Utilização do Material Nuclear", conforme a norma CNEN-NE2.02, 1999.

Como complemento à questão regulatória, a AIEA em seu "Safety Standard Series No. GS-R-1", 2000, define que o governo do país-membro deve garantir a existência de uma infraestrura legal e regulatória adequada para avaliação da segurança do reator nuclear de pesquisa. O regime regulatório deve ser estruturado e com recursos que assegurem o controle dos riscos potenciais provocados pelo reator de pesquisa nuclear. O país-membro deve possuir um órgão regulatório efetivamente independente de outras organizações envolvidas 
com tecnologia nuclear ou que sejam responsáveis por instalações nucleares ou atividades relacionadas à área nuclear.

O IBAMA somente autoriza o início da obra ou instalação do reator de pesquisa nuclear após a aprovação da "Autorização de Supressão de Vegetação", quando exigida, e do "Plano Básico Ambiental" (PBA), que detalha os programas ambientais necessários para a minimização dos impactos negativos e maximização dos impactos positivos que foram identificados na elaboração do EIA.

Nesta etapa de licenciamento da construção, temos uma situação que demonstra um conflito regulatório importante de ser destacado: o modelo CNEN permite o início das atividades de construção de uma instalação sem que a licença de construção tenha sido concedida. Atividades como exploração de escavação, preparação do canteiro de obras, vias de acesso, subestação, linhas de transmissão, edificações temporárias e edificações que não sejam destinadas a itens importantes de segurança exigem interferências no meio ambiente e somente deveriam ser iniciadas quando a Licença de Instalação (ambiental) fosse concedida pelo IBAMA.

Outro ponto importante e que mostra um desalinhamento entre os modelos CNEN e AIEA é a questão da infraestrutura regulatória. Ou seja, a CNEN é o órgão regulatório emissor da "Autorização de Operação Permanente" (nuclear) para os reatores de pesquisa nucleares brasileiros e possui em sua estrutura atividades relacionadas à tecnologia nuclear e operação de instalações nucleares.

O resultado da pesquisa desta etapa não acrescentou considerações significativas que merecessem discussões.

O comissionamento faz parte do processo de licenciamento e este foi um tema unânime tanto nos modelos da AIEA, da CNEN, assim como dos três reatores de pesquisa nucleares. O modelo do IBAMA não possui uma etapa específica para o comissionamento, mas ele está incluso na etapa da Licença de Operação que será abordada a seguir.

A etapa de Operação no modelo da AIEA inclui a utilização do reator de pesquisa nuclear e as modificações na instalação. Entretanto, deixa, a critério do país-membro, a decisão de incluir as possíveis modificações que venham a ser feitas no reator de pesquisa nuclear ou trata-las em outra etapa 
específica. A recomendação da AIEA é tratar separadamente a utilização da modificação, quando houver alterações que possam ter implicações na segurança do reator e requeiram muitas e repetidas análises com sistemáticas avaliações durante a vida da instalação.

Na etapa de Operação do modelo CNEN, utilização e modificações são tratadas separadamente. O modelo faculta ao reator de pesquisa nuclear licenciado, fazer modificações sem que haja a necessidade de aprovação prévia, desde que estas não envolvam questões de segurança ou alterações técnicas às condições estabelecidas nas licenças de construção, ou AOI ("Autorização de Operação Inicial”), ou AOP (“Autorização de Operação Permanente”).

No modelo CNEN, a licença de operação é denominada de "Autorização de Operação" e deve ser requerida em duas etapas complementares: a primeira chamada de "Autorização de Operação Inicial" e a segunda "Autorização de Operação Permanente", AOI e AOP, ambas intrinsicamente relacionadas à operação nuclear do reator de pesquisa. A concessão da AOI pela CNEN ocorrerá quando a construção da instalação estiver substancialmente concluída de acordo com as disposições legais, regulamentares e normativas vigentes e com as condições da licença de construção atendidas. $O$ "Relatório Final de Análise de Segurança" deve ser apresentado junto com o "Plano Final de Proteção Física".

Deverá também haver a garantia de que a operação inicial possa ser conduzida sem risco à saúde, à segurança da população e ao meio ambiente. A "Autorização para Utilização de Material Nuclear" deverá estar aprovada e a equipe que conduzirá a operação estar tecnicamente qualificada conforme as disposições legais, regulamentares e normativas vigentes.

A emissão da AOP ocorrerá quando a construção da instalação estiver concluída de acordo com as disposições legais, regulamentares e normativas vigentes e com as condições da licença de construção atendidas, inclusive seus aditamentos. Como para a AOI, deverá também haver a garantia de que a operação em caráter permanente poderá ser conduzida sem risco à saúde, à segurança da população e ao meio ambiente. A "Autorização para Utilização de Material Nuclear" deverá estar aprovada e a equipe que conduzirá a operação estar tecnicamente qualificada conforme as disposições legais, regulamentares e normativas vigentes. Devem ser apresentados o prazo de operação desejado, o 
RFAS com dos complementares relativos ao reator de pesquisa nuclear, um relatório descritivo descrevendo o desenvolvimento das atividades na fase de AOI, um relatório detalhado dos testes realizados durante a operação inicial, um programa de garantia da qualidade para o reator de pesquisa nuclear e demonstração de que a instalação está completamente terminada, de acordo com as condições estabelecidas na licença de construção, AOI e respectivos aditamentos.

O IBAMA somente aceita a solicitação para emissão da LO quando a instalação do reator de pesquisa nuclear estiver concluída integralmente. Sua concessão está condicionada à inspeção que será realizada para verificar o cumprimento de todas as exigências técnicas determinadas nas etapas das LP e LI. O reator de pesquisa nuclear deverá apresentar os relatórios que demonstram a implantação dos programas ambientais e medidas mitigadoras previstas nas etapas de LP e LI.

O resultado da pesquisa demonstrou que os reatores de pesquisa nucleares precisam se adequar às exigências do IBAMA, uma vez que na ocasião em que foram construídos e iniciaram suas operações, ainda não existiam as atuais disposições legais e os requisitos normativos e regulatórios. As instalações possuem autorizações de operação provisórias.

Uma situação discutível nesta etapa é o desalinhamento da permissão legal para o início da operação entre os modelos CNEN e IBAMA. Enquanto o modelo CNEN permite iniciar a operação com uma $A O I$ para realização de testes e sem que a instalação esteja terminada, o modelo IBAMA somente permite iniciar a operação com a instalação integramente concluída.

A última etapa do modelo da AIEA é o descomissionamento. Em muitos reatores de pesquisa nuclear em operação, o descomissionamento não foi considerado em seu projeto.

O processo de licenciamento da CNEN não menciona descomissionamento assim como o resultado da pesquisa também demonstrou que o descomissionamento não foi considerado na obtenção da Autorização de Operação Permanente. Apesar do descomissionamento não interferir diretamente na operação do reator nuclear de pesquisa, a sua presença é importante no processo, para que as atividades de inspeções, manutenções, alterações na 
instalação entre outras, sejam sempre realizadas com foco na existência futura desta fase. 
TABELA 9 - Matriz comparativa do modelo da AIEA com o modelo regulatório brasileiro (nuclear e ambiental) e o resultado da pesquisa de campo

\begin{tabular}{|c|c|c|c|c|c|c|}
\hline $\begin{array}{l}\text { Etapas do Processo de } \\
\text { Licenciamento }\end{array}$ & AIEA & CNEN & IBAMA & $\begin{array}{l}\text { Reator } \\
\text { IEA-R1 }\end{array}$ & $\begin{array}{c}\text { Reator } \\
\text { IPE/MB-01 }\end{array}$ & $\begin{array}{l}\text { Reator de } \\
\text { Pesquisa } \\
\text { Argonauta }\end{array}$ \\
\hline \multicolumn{7}{|l|}{ Aprovação do Local } \\
\hline Diagnóstico Ambiental & $\begin{array}{l}\text { Sim } \\
\text { Nuclear }\end{array}$ & Parcial & Sim & Sim & Sim & Sim \\
\hline $\begin{array}{l}\text { Consulta a partes } \\
\text { interessadas }\end{array}$ & Não & Não & SIM & Não & $\begin{array}{l}\text { Capítulo } \\
\text { do RAS }\end{array}$ & Desconhece \\
\hline $\begin{array}{l}\text { Estudo de Impactos } \\
\text { Ambientais }\end{array}$ & $\begin{array}{c}\text { Sim } \\
\text { Nuclear }\end{array}$ & Não & Sim & Não & Não & $\begin{array}{l}\text { Parte do } 3^{\circ} \\
\text { capítulo do } \\
\text { volume } 2 \text { do } \\
\text { RAS }\end{array}$ \\
\hline Monitoramento Ambiental & $\begin{array}{c}\text { Sim } \\
\text { Nuclear }\end{array}$ & $\begin{array}{c}\text { Programa } \\
\text { preliminar } \\
\text { de } \\
\text { monitoração } \\
\text { ambienta } \\
\text { pré- } \\
\text { operacional }\end{array}$ & $\begin{array}{c}\text { Sim } \\
\text { Todos os } \\
\text { aspectos } \\
\text { ambientais }\end{array}$ & $\begin{array}{c}\text { Sim } \\
\text { aspectos } \\
\text { nuclear }\end{array}$ & $\begin{array}{c}\text { Sim } \\
\text { aspectos } \\
\text { nuclear }\end{array}$ & $\begin{array}{l}\text { Sim } \\
\text { aspectos } \\
\text { nuclear }\end{array}$ \\
\hline
\end{tabular}




\begin{tabular}{|c|c|c|c|c|c|c|}
\hline $\begin{array}{l}\text { Etapa do Processo de } \\
\text { Licenciamento }\end{array}$ & AIEA & CNEN & IBAMA & $\begin{array}{l}\text { Reator } \\
\text { IEA -R1 }\end{array}$ & $\begin{array}{c}\text { Reator } \\
\text { IPE/MB-01 }\end{array}$ & $\begin{array}{l}\text { Reator de } \\
\text { Pesquisa } \\
\text { Argonauta }\end{array}$ \\
\hline \multicolumn{7}{|l|}{ Projeto e Construção } \\
\hline Critérios de Projeto & Sim & Sim & Não & Sim & Sim & Sim \\
\hline Normas e Códigos & Sim & Sim & Não & Sim & Sim & Sim \\
\hline Limites de Projeto & Sim & Sim & Não & Sim & Sim & Sim \\
\hline Classificação de Sistemas & Sim & Sim & Não & Sim & Sim & Sim \\
\hline Proteção ao Meio Ambiente & $\begin{array}{c}\text { Sim } \\
\text { nuclear }\end{array}$ & $\begin{array}{c}\text { Sim } \\
\text { nuclear }\end{array}$ & Sim & $\begin{array}{c}\text { Sim } \\
\text { nuclear }\end{array}$ & $\begin{array}{c}\text { Sim } \\
\text { nuclear }\end{array}$ & $\begin{array}{c}\text { Sim } \\
\text { nuclear }\end{array}$ \\
\hline $\begin{array}{l}\text { Autorização do órgão } \\
\text { regulador }\end{array}$ & Sim & Sim & Sim & Sim & Sim & Sim \\
\hline \multicolumn{7}{|l|}{ Comissionamento } \\
\hline $\begin{array}{l}\text { Parte do processo de } \\
\text { licenciamento }\end{array}$ & Sim & Sim & Não & Sim & Sim & Sim \\
\hline
\end{tabular}




\begin{tabular}{|c|c|c|c|c|c|c|}
\hline $\begin{array}{l}\text { Etapa do Processo de } \\
\text { Licenciamento }\end{array}$ & AIEA & CNEN & IBAMA & $\begin{array}{l}\text { Reator } \\
\text { IEA -R1 }\end{array}$ & $\begin{array}{c}\text { Reator } \\
\text { IPE/MB-01 }\end{array}$ & $\begin{array}{l}\text { Reator de } \\
\text { Pesquisa } \\
\text { Argonauta }\end{array}$ \\
\hline \multicolumn{7}{|l|}{ Operação } \\
\hline Licença de operação & Sim & $\begin{array}{c}\text { Sim } \\
\text { Nuclear }\end{array}$ & Sim & $\begin{array}{c}\text { Conforme } \\
\text { norma } \\
\text { CNEN-NE- } \\
1.04\end{array}$ & $\begin{array}{l}\text { Relatórios } \\
\text { técnicos } \\
\text { descreven } \\
\text { do cada } \\
\text { um dos } \\
\text { sistemas } \\
\text { comissiona } \\
\text { dos e } \\
\text { enviados à } \\
\text { CNEN }\end{array}$ & $\begin{array}{c}\text { Estabelecim } \\
\text { ento de um } \\
\text { programa } \\
\text { de } \\
\text { formação, } \\
\text { treinamento } \\
\text { e } \\
\text { requalificaç } \\
\text { ão para } \\
\text { operadores } \\
\text { de reator }\end{array}$ \\
\hline \multicolumn{7}{|l|}{ Descomissionamento } \\
\hline $\begin{array}{l}\text { Parte do processo de } \\
\text { licenciamento }\end{array}$ & Sim & Não & Não & Não & Sim & Não \\
\hline
\end{tabular}




\section{PROPOSTA DE UMA ESTRUTURA REGULATÓRIA INTEGRADA}

A proposta de uma estrutura regulatória integrada está formulada e consistente com o resultado da pesquisa de campo, com a análise comparativa entre os modelos da AIEA e da CNEN e com as análises e interpretações apresentadas nas TAB. 8 e 9, assim como com os resultados dos estudos exploratórios apresentados na revisão da literatura descrita no capítulo 3 .

São observados na proposição da estrutura, os objetivos propostos para este estudo, assim como as questões de pesquisa apresentados nos capítulos 1 e 2 .

A partir dos pressupostos descritos na TAB. 10, é apresentada na sequência a matriz contendo a proposta da estrutura regulatória integrada para o licenciamento de reatores nucleares de pesquisa (vide TAB. 11).

TABELA 10 - Pressupostos para proposta da estrutura integrada e as questões de pesquisa

\begin{tabular}{l} 
Questões da pesquisa \\
\hline Como obter uma proposta de estrutura \\
regulatória integrada com abordagem \\
em qualidade e meio ambiente com \\
vistas à harmonização das fases do \\
processo de licenciamento de reatores \\
nucleares de pesquisa no Brasil?
\end{tabular}

\section{Pressupostos}

- Gestão do processo de licenciamento por um órgão regulatório brasileiro;

- Reestruturação dos modelos existentes de licenciamento nuclear e licenciamento ambiental para um modelo único que contemple uma estrutura integrada abrangente e harmonizada com as exigências regulatórias nucleares e ambientais;

- Harmonização da estrutura regulatória integrada brasileira com a estrutura do modelo internacional da AIEA;

- Considerar na estrutura regulatória integrada, modelos de gestão da qualidade e de meio ambiente;

\begin{tabular}{|c|c|}
\hline $\begin{array}{l}\text { É possível identificar os conflitos } \\
\text { existentes nos processos de } \\
\text { licenciamento em nível ambiental e } \\
\text { nuclear no país e propor soluções? }\end{array}$ & $\begin{array}{l}\text { - Foram revelados conflitos e } \\
\text { inconsistências entre as fases dos } \\
\text { processos de licenciamento vigentes } \\
\text { no Brasil. Os conflitos estão } \\
\text { identificados desde a autorização } \\
\text { para início da instalação do reator } \\
\text { nuclear de pesquisa, passando pela } \\
\text { licença para iniciar a construção até } \\
\text { o licenciamento final para iniciar a } \\
\text { operação: }\end{array}$ \\
\hline
\end{tabular}




\begin{tabular}{|c|c|}
\hline Questões da pesquisa & Pressupostos \\
\hline & 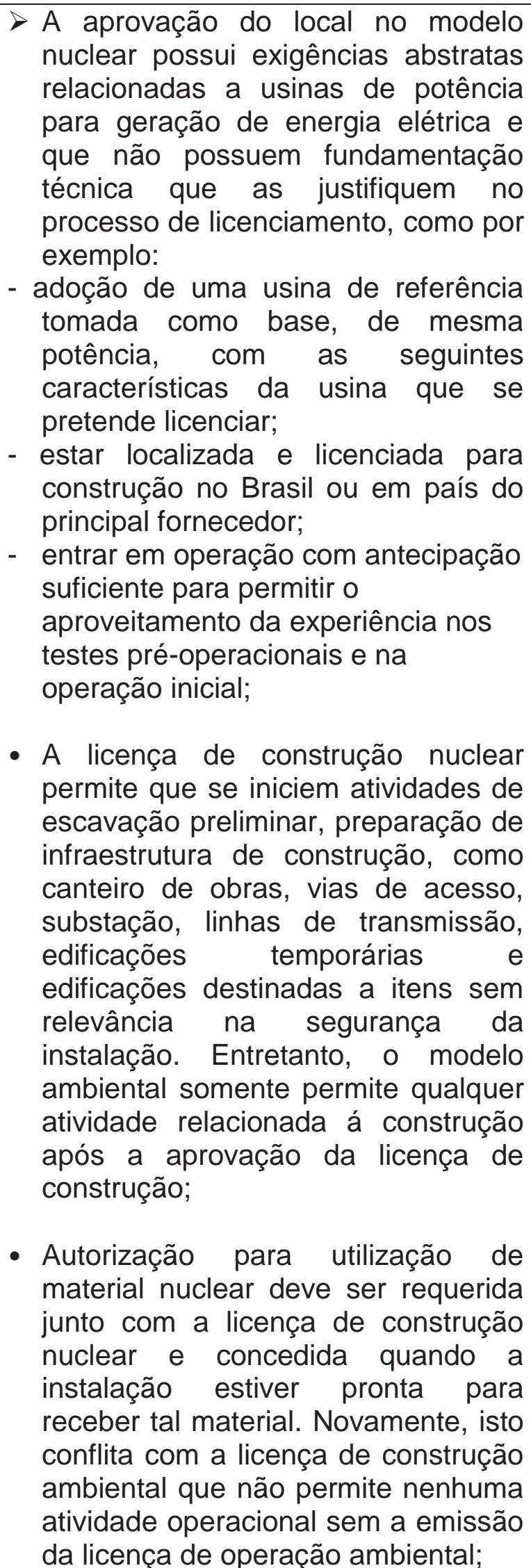 \\
\hline
\end{tabular}




\begin{tabular}{l|l}
\hline Questões da pesquisa & \multicolumn{1}{c}{ Pressupostos } \\
\hline & $\begin{array}{l}\text { O modelo de licenciamento nuclear } \\
\text { permite o início da operação com } \\
\text { uma autorização de operação inicial, } \\
\text { quando o modelo ambiental somente } \\
\text { permite qualquer atividade } \\
\text { relacionada à operação após a } \\
\text { emissão da licença de operação; }\end{array}$ \\
\hline
\end{tabular}

\begin{tabular}{l|l}
\hline Questões da pesquisa & \multicolumn{1}{c}{ Pressupostos } \\
\hline & $\begin{array}{l}\text { Também foram identificadas questões } \\
\text { na fase de descomissionamento que } \\
\text { podem ser consideradas como conflitos }\end{array}$ \\
ou apenas interpretações localizadas \\
que deverão ser harmonizadas na \\
estrutura regulatória integrada.
\end{tabular}

TABELA 11 - Matriz da proposta para a estrutura regulatória integrada

- A gestão do processo de licenciamento e a emissão da licença final devem estar na responsabilidade de um órgão regulatório;

Gestão

- O órgão regulatório responsável pelo processo de licenciamento e emissor da licença de operação deve contar com recursos humanos competentes em meio ambiente e segurança nuclear para avaliar e acompanhar o desenvolvimento do processo em todas as fases do licenciamento.

Os seguintes documentos e informações devem ser apresentados e aprovados para que o local da instalação do reator nuclear de pesquisa seja aprovado pelo órgão

Fase 1 regulatório:

1) Memorial Descritivo do Projeto contendo no mínimo:

Avaliação
do
Local

1.1) Características gerais do projeto e de operação do reator nuclear de pesquisa;

1.2) Objetivo da instalação do reator nuclear de pesquisa;

1.3) Capacidade nominal;

1.4) Natureza e inventário dos materiais radioativos a serem contidos na instalação;

1.5) Distribuição da população, vias de acesso 


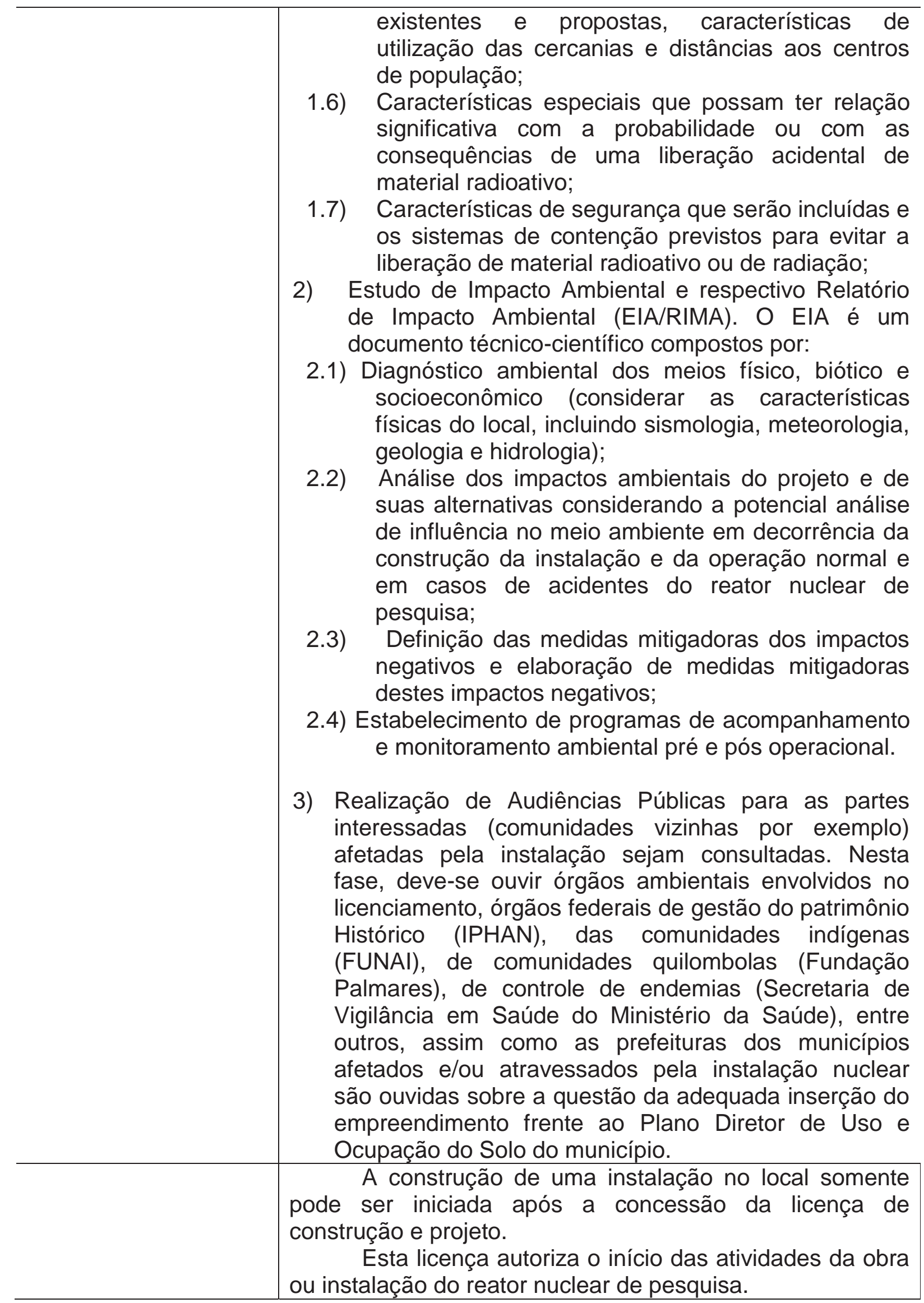


Fase 2

Licença

de

Construção e Projeto
Os seguintes documentos e informações devem ser apresentados e aprovados para que o local da instalação do reator nuclear de pesquisa seja aprovado pelo órgão regulatório:

1) Local em que o reator nuclear de pesquisa venha a ser instalado e que implique em desmatamento, deverá ser obtida uma "Autorização de Supressão de Vegetação";

2) Cronograma da obra e os prazos, máximo e mínimo, estimados para término da construção pretendida (o prazo de validade dessa licença é estabelecido pelo cronograma de instalação do reator nuclear de pesquisa não pode ser superior a 6 (seis) anos);

3) Programa de gestão ambiental que deverá considerar um planejamento básico ambiental (em conformidade com o plano básico ambiental -PBA) com detalhamento de todos os programas ambientais necessários à minimização dos impactos negativos e maximização dos impactos positivos, identificados quando da elaboração do EIA (deverão ser consideradas as exigências ambientais legais como controles operacionais, monitoramentos ambientais, manuseio, estocagem e descartes de resíduos, entre outros);

4) Programa de gestão da qualidade incluindo todos os requisitos do programa de garantia da qualidade para as atividades e processos de gerenciamento, projeto, fabricação, aquisição, construção, montagem eletromecânica, treinamento e operação;

5) Relatório Preliminar de Análise de Segurança (RPAS);

6) Plano Preliminar de Proteção Física;

7) Verificação e aprovação do projeto (incluindo os principais critérios de arquitetura e engenharia do projeto e as principais características ou itens nele incorporados para proteção do meio ambiente e da população, além dos dispositivos e/ou componentes de segurança que exijam pesquisa e desenvolvimento, e que tenha sido estabelecido um programa de pesquisa e desenvolvimento objetivando solucionar quaisquer problemas de segurança associados a esses dispositivos e/ou componentes;

8) Autorização do órgão regulatório para iniciar a fabricação de componentes previamente definidos no projeto;

Os testes e a operação do reator de pesquisa nuclear somente poderão serem iniciados após a aprovação da inspeção na instalação para verificar se 


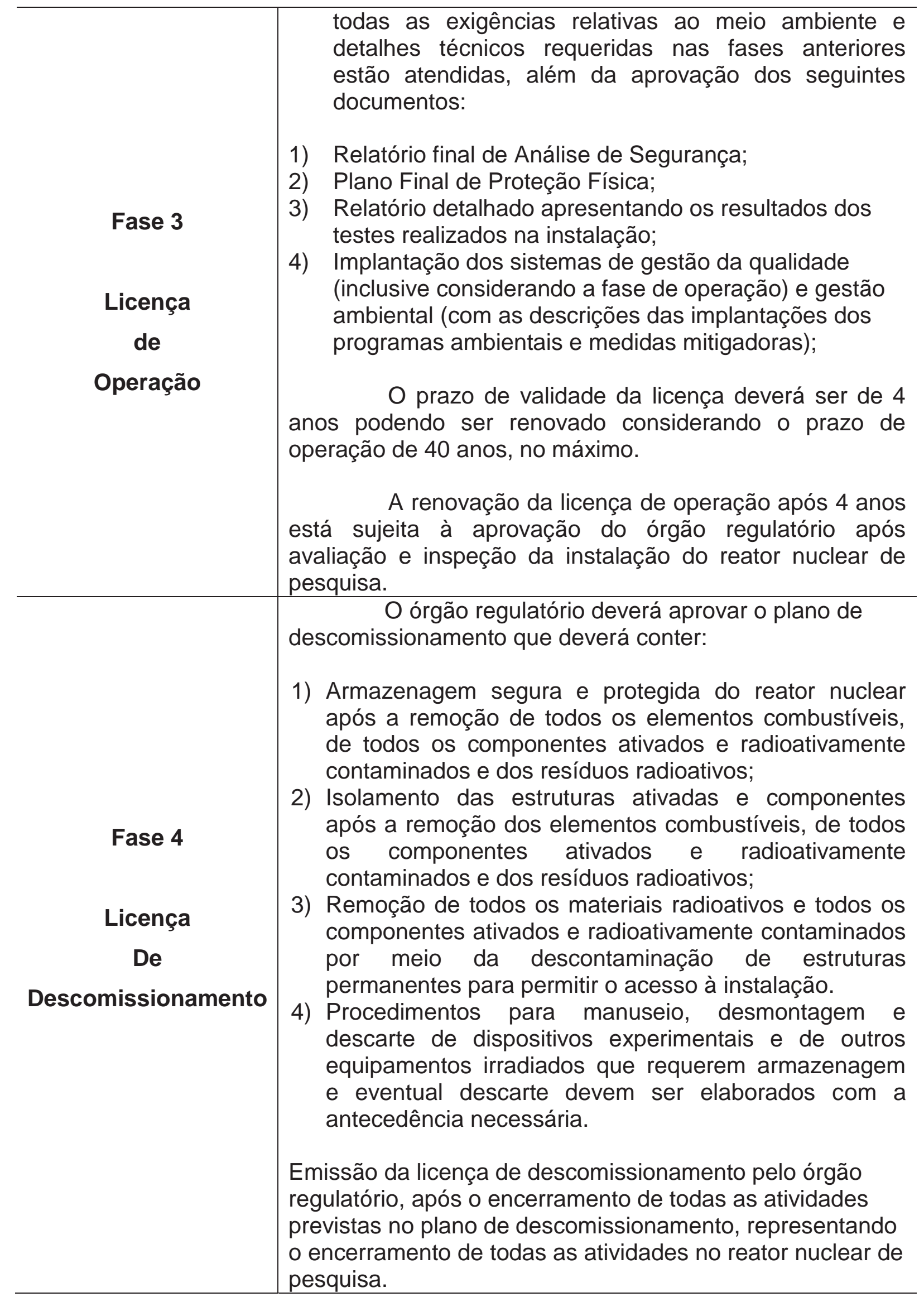


Com base na matriz da proposta da estrutura regulatória integrada, foi desenvolvida uma análise de SWOT, cujos pontos fortes, pontos fracos, oportunidades e ameaças estão descritos a seguir (vide FIG. 10).

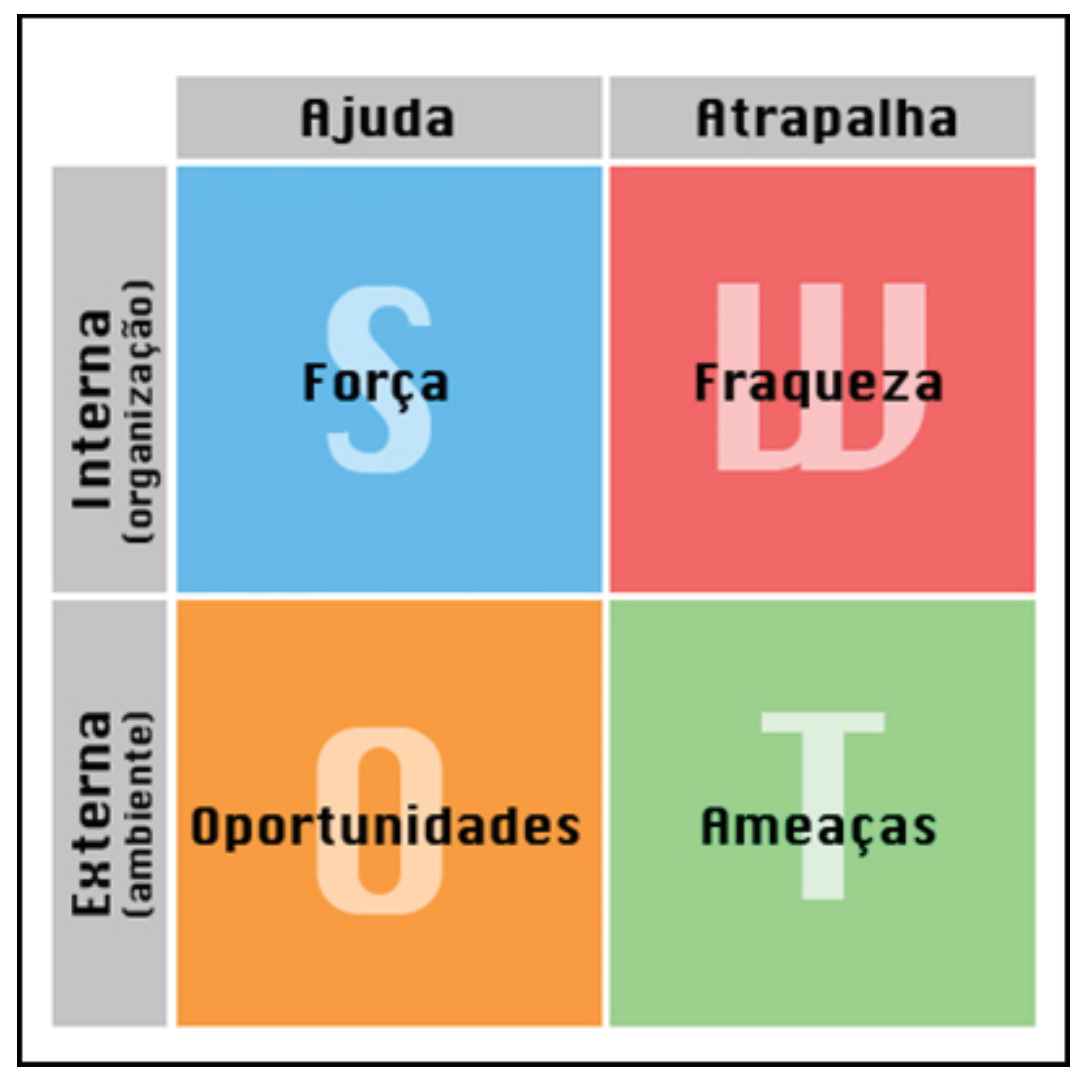

FIGURA 10 - Matriz SWOT

Fonte: http://www.portal-administracao.com/2014/01/analise-swot-conceito-e-aplicacao.html. Acesso em: $14 / 11 / 2014$.

\section{Pontos Fortes}

a) Maior agilidade para obtenção da licença de operação;

b) Haverá somente um canal de comunicação para o requerente do licenciamento. Gestão por um órgão regulatório;

c) Harmonização e integração regulatória;

d) Comunicação e compartilhamento de informações trazendo maior efetividade no processo de licenciamento;

e) Otimização de recursos;

f) Uniformidade de decisões evitando conflitos nas informações transmitidas aos requerentes; 
g) Ênfase na gestão integrada : qualidade e meio ambiente;

h) Possibilidade de implementar modelos de gestão de qualidade e meio ambiente com base nas normas ISO 9001 e 14001, largamente utilizados pelas empresas;

i) A estrutura proposta atende o modelo internacional da da AIEA e é derivada dos modelos nuclear e ambiental vigentes;

\section{Pontos Fracos}

a) O trabalho em conjunto depende da atuação dos profissionais com competência para conduzir harmonicamente o processo de licenciamento. Atualmente, os dois orgãos regulatórios encontram-se na órbita federal e devem ser bem preparados para esta atividade;

b) Profissionais com formação em meio ambiente sem conhecimento da área nuclear;

\section{Oportunidades}

a) Atualização das normas regulatórias nucleares;

b) Inclusão dos modelos de sistemas de gestão da qualidade e meio ambiente com base na ISO 9001 e ISO 14001;

c) Desenvolvimento de uma estrutura regulatória mais objetiva e realista às necessidades do país;

d) Desenvolvimento de competências no setor nuclear;

e) Redução de custos com maior eficiência no acompanhamento do processo de licenciamento;

\section{Ameaças}

a) Dificuldade em unir a gestão de 2 processos, atualmente independentes, em um orgão regulatório;

b) Dificuldade em estabelecer os limites de atuação do órgão regulatório gestor;

c) Aceitação pelo órgão regulatório parceiro em ceder autoridade e decisão do processo de licenciamento;

d) Resistência em alterar legislação, uma vez que a sociedade mostrase contrária à utilização de instalações nucleares. 


\section{CONCLUSÔES E RECOMENDAÇÔES}

Este trabalho teve como objetivo estudar o processo de licenciamento de reatores de pesquisa nucleares no Brasil, visando desenvolver uma proposta de estrutura regulatória integrada, com suas fases harmonizadas e abordagem em qualidade e meio ambiente, como contribuição ao caso brasileiro.

A pesquisa foi desenvolvida com base nas premissas, objetivos e questões de pesquisa estabelecidos no capítulo 2.

Na pesquisa, foram estudados os processos de licenciamento de reatores de países como a França, Coréia do Sul, Canadá, Austrália, Holanda, Egito e o próprio Brasil, sendo todos Países Membros da AIEA. Dentre estes países, o Canadá é o país cuja estrutura regulatória possui as mesmas fases da estrutura proposta pela AIEA, considerando inclusive como fase adicional, a "Licença para Abandono da Instalação", após a emissão da "Licença de Descomissionamento", como documento final e que encerra o processo de licenciamento do reator nuclear de pesquisa.

À exceção do Canadá, nenhum outro país possui, em sua estrutura regulatória, uma fase claramente definida para o descomissionamento.

A estrutura regulatória francesa envolve o Ministério da Indústria, que é o emissor das licenças, mais particularmente por meio do Serviço Central de Segurança de Instalações Nucleares, que recebe apoio técnico do Departamento de Segurança Nuclear pertencente ao Instituto de Proteção e de Segurança Nuclear da Comissão de Energia Atômica.

Basicamente, a estrutura regulatória está apoiada em três relatórios de segurança que atendem à estrutura da AIEA, com algumas particularidades. São eles:

1. O relatório de segurança preliminar enviado ao SCSIN na ocasião em que a licença de construção é requerida e antes do início de qualquer atividade no local em que o empreendimento será construído. Esse relatório deve conter as intenções, a descrição geral do reator e as regras e critérios de segurança que serão seguidas e deve ser liberado por um mecanismo da legislação francesa denominado "Decreto de Criação"; 
2. O relatório de segurança provisório encaminhado no máximo seis meses antes da primeira carga de combustível no núcleo do reator, mencionando a situação do reator de pesquisa nuclear (este deverá estar praticamente concluído) juntamente com a "Autorização de Carregamento";

3. O relatório de segurança final, usualmente apresentado após um ano de operação e que considera toda a experiência adquirida e incorporada, os resultados dos testes, as possíveis modificações da instalação e as regras finais de operação. Somente com este relatório aprovado, o Ministério da Indústria emitirá "Autorização de Operação".

O processo de licenciamento francês prevê audiências públicas, mas não foi encontrado na literatura o momento em que elas são realizadas.

A estrutura regulatória coreana está distribuída em duas fases, apesar de haver uma terceira fase, não claramente denominada, em que há aprovação do local com base em um relatório do local e de estudo geológico detalhado para emissão de autorização de trabalho limitado, antes da "Permissão para Construção".

Na fase denominada de "Permissão para Construção" são analisados a segurança do projeto (atendimento aos códigos e normas relacionadas aos requisitos regulatórios), impactos ambientais e medidas de mitigação para reduzir seus efeitos. Nesta primeira fase, o documento mais importante é o "Relatório Preliminar de Análise de Segurança" (RPAS) e o "Relatório Ambiental" (RA).

$\mathrm{Na}$ fase seguinte, Licenciamento da Operação, a segurança da planta é avaliada para confirmar a conformidade do projeto com os critérios de aceitação. Os principais documentos requeridos para emissão da licença de operação são o "Relatório de Análise de Segurança Final” (FSAR), as "Especificações Técnicas" e o "Plano de Emergência Radiológica".

Os processos de licenciamento de reatores nucleares de pesquisa australianos seguem uma estrutura regulatória integrada, em 3 fases, que estão alinhadas com a AIEA, à exceção da fase de descomissionamento, não referenciada na literatura disponível sobre o assunto. 
Na primeira fase, denominada de "Autorização para Preparação do Local”, foi autorizado o início de atividades sem qualquer tipo de construção, como realizar estudos de solo, água, estabelecer caracterização radiológica do local e seguir todas as condicionantes descritas pela ARPANSA na Autorização para Preparação do Local. Um dos principais documentos que serviram como base técnica para esta licença foi a "Declaração de Impactos Ambientais" ("Environmental Impacts Statement"-EIS). Outros documentos também tecnicamente importantes e que promoveram o suporte técnico desta licença foram o - "Relatório de Análise de Segurança do Local" - (considerando as características e as bases de projeto) e o "Relatório de Análise de Acidentes".

No Egito, o NCNSRC, que é o órgão criado pela Autoridade em Energia Atômica (AEA), responsável por regular e controlar o projeto, construção e operação de instalações nucleares, adota uma estrutura regulatória muito bem definida com quatro fases alinhadas com a AIEA:

- $\quad$ Aprovação do local;

- $\quad$ Permissão para construção;

- $\quad$ Autorização para carregamento de combustível; e

- $\quad$ Licença de operação

Entretanto, não foi encontrada nenhuma referência às questões ambientais, o que coloca em dúvida a integração e harmonização desta estrutura. Também não foi encontrado referência à fase de descomissionamento.

Neste estudo exploratório, foi observado que as estruturas de todos os processos de licenciamento dos reatores nucleares de pesquisa variam entre si nas suas fases executivas, mas procuram seguir o modelo proposto pela AIEA, sempre iniciando com a avaliação do local, porém nem sempre evoluindo até o descomissionamento.

Como primeira conclusão, podemos dizer que a fase de descomissionamento é extremamente importante e deve ser incluída em uma estrutura regulatória, pois, apesar de não interferir e nem afetar diretamente a operação do reator nuclear de pesquisa, ela deve ser licenciada e compor o processo de licenciamento da instalação, mesmo acontecendo somente ao fim da sua vida operacional. Isto porque, desde a realização do projeto da instalação, o 
descomissionamento deve ser previsto com detalhes que facilitem a sua desmobilização por ocasião do descomissionamento. Da mesma forma, ao longo da vida operacional do reator, as atividades operacionais como inspeções, testes periódicos, manutenções, modificações e experimentos, devem ser conduzidos e executados de tal forma que facilitem o descomissionamento. Também está incluído neste direcionamento, a documentação do reator nuclear de pesquisa. É importante, que toda documentação técnica do reator nuclear de pesquisa seja mantida sempre atualizada com os registros de informações e experiências relacionadas ao manuseio de estruturas, sistemas e componentes contaminados e irradiados durante as atividades de manutenção ou modificações do reator, para assim facilitar o planejamento do descomissionamento. Desenhos de modificações, alterações realizadas, registros de manutenções, de inspeções e procedimentos técnicos para manuseio e desmontagem de estruturas, sistemas e componentes contaminados e irradiados, juntamente com procedimentos ambientais para descartes, transporte e armazenagem destes materiais devem ser estar previstos nesta fase.

Com base na metodologia da pesquisa, foram aplicados os fundamentos do método hipotético-dedutivo para o planejamento e execução das etapas deste estudo. A ausência de informações do Reator de Pesquisa Triga IPRR1 foi contemplada na aplicação da metodologia, não influenciando no resultado do estudo. Assim, um instrumento de pesquisa foi desenvolvido e aplicado juntamente a realização de entrevistas. Foram analisadas três experiências nacionais que permitiram conhecer os detalhes do processo de licenciamento brasileiro, considerando-se, principalmente, as dimensões estabelecidas no instrumento de pesquisa, a saber: aspectos relacionados ao local: localização, população, acesso, diagnóstico ambiental do local, comunicação e consultas a partes interessadas, estudo dos impactos ambientais, monitoração ambiental; aspectos relacionados à infraestrutura e legislação regulatória do local em que o reator de pesquisa nuclear será instalado: órgãos responsáveis, planejamento e informações técnicas sobre qualidade, meio ambiente e segurança da instalação, programas ambientais específicos à instalação do reator nuclear de pesquisa desde a construção até a sua operação plena; aspectos relacionados ao projeto e construção: códigos, normas, avaliação do projeto , fabricação, planejamento ambiental; aspectos relacionados ao 
comissionamento: autorizações, programas de testes; aspectos relacionados à operação: resultados de testes pré-operacionais realizados e resultados das inspeções ambientais; aspectos relacionados ao descomissionamento: previsão sobre planejamento de atividades para interrupção e desmobilização da instalação e os aspectos relacionados ao programa de garantia da qualidade: foram verificados os critérios adotados para elaboração do programa de garantia da qualidade, seu conteúdo e a base regulatória.

O resultado da pesquisa de campo permitiu chegar às seguintes conclusões:

A construção dos reatores nucleares de pesquisa IEA-R1 e Argonauta antecedem a legislação ambiental. O reator IPEN-MB-01 iniciou suas atividades após a Resolução CONAMA 01/1986, mas em uma época em que o licenciamento estava exclusivamente sob a responsabilidade da CNEN;

$\checkmark \quad$ As atividades e os experimentos previstos para serem realizados nos reatores de pesquisa não estão descritos nas licenças de operação do IEA -R1 e do IPEN-MB-01. Somente no Argonauta.

$\checkmark \quad$ O monitoramento ambiental está restrito aos parâmetros nucleares;

$\checkmark$ Os critérios de projeto, normas, códigos, limites, classificação de sistemas entre outros, foram contemplados no processo de licenciamento, apesar de não haver uma fase específica nas atuais estruturas regulatórias brasileiras;

As exigências ambientais para iniciar a construção de reatores de pesquisa nucleares são distintas e conflitantes nos processos vigentes para licenciamento das instalações nucleares. ;

$\checkmark \quad$ A fase do processo de licenciamento nuclear "Autorização para utilização de material nuclear" é concedida independentemente da instalação estar totalmente concluída para iniciar a operação;

O comissionamento da instalação não constitui uma fase do processo de licenciamento. Entretanto, ele está contemplado na fase de construção do processo de licenciamento nuclear; 
$\checkmark \quad$ O descomissionamento não foi abordado em nenhuma das experiências analisadas;

O Programa de Garantia da Qualidade é uma exigência do modelo de licenciamento da AIEA e integrante do modelo brasileiro. Porém, como a própria nomenclatura já menciona, ele está direcionado somente para o tema "Garantia da Qualidade", quando atualmente evoluímos para Gestão Integrada, que combina a qualidade com o meio ambiente, não somente Garantia da Qualidade.

Com os resultados da pesquisa de campo e do estudo realizado com a revisão bibliográfica, foi realizada a análise e discussão dos resultados, sendo apresentada, na sequência, a proposta da estrutura regulatória integrada.

Nesta etapa, são respondidas as questões de pesquisa, conforme se segue:

- Primeira questão: É possível identificar os conflitos existentes nos processos de licenciamento em nível ambiental e nuclear no país e propor soluções?

A resposta está na constatação da existência de conflitos significativos em todas as fases dos processos nuclear e ambiental brasileiro, independentemente da divergência do número de fases, que não é relevante para esta questão. Os principais conflitos residem no conteúdo destas fases que não são harmonizadas. $O$ processo de licenciamento nuclear permite que o local em que o empreendimento for instalado seja aprovado sem que todos os estudos de impacto ambiental estejam concluídos e aprovados. Da mesma forma, permite também que sejam iniciadas e realizadas, algumas atividades relacionadas à construção no local previsto para o empreendimento, sem que a licença de construção esteja aprovada pelo próprio órgão regulador da área nuclear.

Outro conflito significativo está na fase das licenças de construção (nuclear) e de instalação (ambiental). Enquanto o órgão regulador ambiental, IBAMA, determina que somente após a emissão da licença de instalação as atividades de construção poderão ser iniciadas, o órgão regulador nuclear, a CNEN, permite o início de atividades preliminares de construção sem a respectiva licença e ainda iniciar a construção com a emissão de uma licença de construção parcial com 
pendências relacionadas ao meio ambiente, conforme mencionado no item 6.3.1.1alínea b, da norma CNEN-NE-1.04 (2002).

No processo de licenciamento nuclear brasileiro, há uma fase em que deve ser obtida a "Autorização para Utilização de Materiais Nucleares", que deve ser requerida junto com a licença de construção, de acordo com a CNEN-NE-1.04 (2002). A autorização será concedida após a comprovação de que a instalação está pronta para receber os materiais nucleares e atendimento à norma CNEN-NE-2.02 (1999), que não aborda questões ambientais. Considerando a importância desta autorização para o processo de licenciamento de reatores nucleares de pesquisa, esta fase foi mantida na proposta da estrutura regulatória integrada entre a completa finalização da fase de construção e o início da fase de operação. O termo empregado "completa finalização" significa que a "Autorização para Utilização de Materiais Nucleares" somente deverá ser concedida quando a fase de construção estiver efetivamente concluída com o cumprimento de todas as exigências normativas e requisitos regulatórios relacionados às questões nucleares e ambientais definidos atualmente de licenciamento da construção nuclear e licenciamento prévio ambiental.

$\mathrm{Na}$ fase de licenciamento da operação também foram identificados conflitos que interferem e atrasam o início da operação dos reatores nucleares de pesquisa. Enquanto o processo de licenciamento ambiental define que a operação somente pode ser iniciada após o atendimento às exigências e detalhes técnicos descritos no projeto aprovado e se todas estão de acordo com o previsto nas LP e LI, o processo de licenciamento nuclear divide esta fase em 2 subfases: Autorização para Operação Inicial e Autorização para Operação Permanente.

Sabemos que testes pré-operacionais com o funcionamento dos equipamentos, sistemas e componentes à temperatura ambiente e a temperatura real de operação, a quente, pode-se concluir que a divisão desta fase em duas subfases é muito sensata sob a ótica técnica e operacional. A integração e harmonização desta fase, traz à proposta regulatória as exigências ambientais definidas pelo IBAMA em sua fase de licenciamento operacional. Ou seja, as exigências ambientais devem ser inseridas e harmonizadas com os requisitos 
regulatórios nucleares para emissão da Autorização para Operação Inicial. A Autorização de Operação Permanente pode ser mantida conforme determinado na norma CNEN CNEN-NE-1.04 (2002).

- Segunda questão: Como obter uma proposta de estrutura regulatória integrada com abordagem em qualidade e meio ambiente com vistas à harmonização das fases do processo de licenciamento de reatores nucleares de pesquisa no Brasil?

Esta questão foi respondida com os resultados obtidos a partir da aplicação da metodologia utilizada para desenvolver o trabalho. O estudo das normas e regulamentos nacionais e internacionais, os resultados obtidos da análise comparativa entre as etapas dos modelos regulatórios brasileiros, onde foram identificados os conflitos existentes entre os processos de licenciamento nuclear e ambiental e as análises realizadas com os resultados dos questionários aplicados na pesquisa de campo, permitiram a elaboração da proposta de uma estrutura regulatória integrada e um processo de licenciamento com fases harmonizadas.

Como recomendações para estudos futuros, foram identificadas oportunidades que poderão ser contribuir para a construção de um processo de licenciamento de reatores nucleares de pesquisa com uma estrutura regulatória mais sólida e eficaz:

Revisar a norma CNEN-NE-1.04 de dezembro de 2002 Licenciamento de Instalações Nucleares;

$>$ Unificar e integrar as questões nucleares e ambientas no processo de licenciamento der reatores nucleares de pesquisa;

> Implementar uma estrutura regulatória integrada no processo de licenciamento de reatores nucleares de pesquisa;

> Considerar o descomissionamento como uma fase do processo de licenciamento do reator nuclear de pesquisa, com abordagens desde o projeto até a operação, e emissão de uma licença de descomissionamento que valide todo o processo e ateste 0 encerramento das atividades no reator nuclear de pesquisa; 
$>$ Evoluir o programa de garantia da qualidade para um modelo integrado em qualidade, meio ambiente e segurança. A própria AIEA possui o Safety Standard Series, GS-R-3, The Management System for Facilities and Activities, que aproxima as instalações do modelo de gestão ISO 9001, mas ainda não contempla a combinação com os modelos de meio ambiente (ISO 14001) e segurança e saúde ocupacional (OHSAS 18001);

$>$ Definir um órgão regulatório como gestor do processo de licenciamento. Este órgão seria o emissor da licença do reator nuclear de pesquisa;

> Definir equipes com competências técnicas nas áreas de projeto, qualidade, meio ambiente e segurança para participarem do processo de licenciamento de reatores nucleares de pesquisa;

Como comentários finais, é importante ressaltar que uma das grandes dificuldades e limitações para desenvolver este trabalho, foi o fato de não existir no país um caso de licenciamento integrado para ser comparado com a presente proposta.

Entretanto, mesmo com esta limitação, pode-se concluir que a estrutura regulatória integrada, proposta no trabalho, está pronta para ser incorporada ao processo de licenciamento atual, desde que sejam introduzidas algumas das recomendações descritas anteriormente. 
APÊNDICE A - Questionário de pesquisa 


\section{Ficha de Identificação/Identification Card}

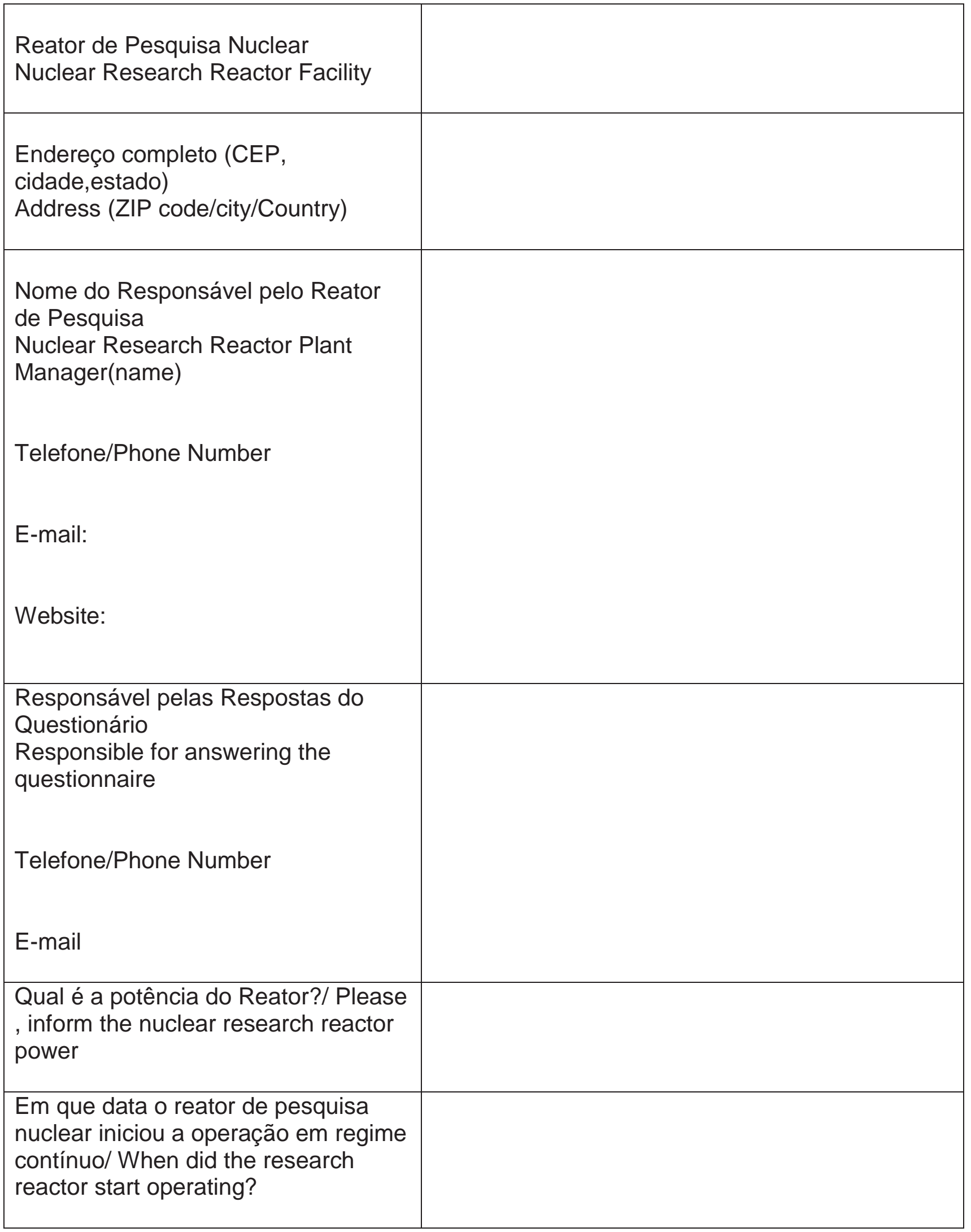


Parte 1- Informações sobre o local da instalação do reator nuclear de pesquisa Information about the place where the research nuclear reactor has been installed

1.1) O reator de pesquisa está localizado em um centro urbano? / Is the nuclear research reactor installed in an urban center?

1.1.1) $\square$ Sim. Informar a população, vias de acesso existentes, rodovias, características de utilização no seu entorno. / Yes. Could you please inform the neighbor population, if there are streets and roads to get at the nuclear research reactor and the local characteristics?

1.1.2) $\square \quad$ Não. Informar o local e a distância ao mais próximo centro urbano / No. Could you please inform the distance to nearest urban center?

1.2) Quantos colaboradores estão envolvidos na operação do reator de pesquisa? I How many employees has been involved with the operation of the nuclear research reactor?

\begin{tabular}{|l|l|}
\hline \multicolumn{1}{|c|}{ Atividades / Activities } & $\begin{array}{c}\text { No. de colaboradores } \\
\text { NR. employees }\end{array}$ \\
\hline Operação / Operation & \\
\hline Manutenção / Maintenance & \\
\hline $\begin{array}{l}\text { Garantia da Qualidade } \\
\text { Quality / Assurance }\end{array}$ & \\
\hline $\begin{array}{l}\text { Gestão Ambiental } \\
\text { Environmental Management }\end{array}$ & \\
\hline Total & \\
\hline
\end{tabular}

1.4) Foi realizado um diagnóstico ambiental do local de instalação do reator ? / Is there an environmental diagnostic concerned to the nuclear research reactor site?

$\operatorname{Sim} /$ Yes

Não/No

1.5) Se sim, o diagnóstico ambiental está disponível às partes interessadas? Informar local para acesso (website) / If yes, it is available to the interested parts? Please inform the website address to access the document? 
1.6) As partes interessadas foram consultadas para definição do local de instalação do reator? / Has been the interested parts participated of the nuclear research reactor site evaluation?

Sim. Informar como foi realizado o processo de consulta às partes interessadas / Yes. How is this participation?

Não / No

1.7) Foi realizado um estudo dos impactos ambientais e características físicas do local de instalação do reator e emitido um relatório contendo o resultado deste estudo? / Is there an environmental impact report about the nuclear research reactor site ? Does this report include the physics characteristic of the nuclear research reactor site?

Sim. Informar o acesso ao relatório de estudos de impactos ambientais e características físicas do local do reator / Yes. Please, inform the website access to get the environmental impact report.

Não há estudos relacionados aos impactos ambientais do local do reator / No. There is no environmental impact study about nuclear research reactor site.

1.8) Que informações relacionadas à instalação nuclear foram consideradas para aprovação do local do reator nuclear (exemplo: natureza e inventário dos materiais radioativos)? / Which kind information related to the nuclear facility were considered for approving the nuclear research reactor site (origin and inventory of the radioactive material)?

1.9) O reator de pesquisa possui um programa de acompanhamento e monitoramento ambiental? / Has the nuclear research reactor an environmental monitoring program?

Sim. Quais os parâmetros monitorados? / Yes. / Which parameters have been monitored?

$\square$ Os parâmetros monitorados seguem alguma legislação ambiental?/ Have the environmental monitored parameters been implemented according to environmental legislation?

Sim. Informar a legislação/ Yes, please inform the legislation 
Normas da CNEN .

Não /No

\section{Parte 2- Aspectos relacionados com a infraestrutura legal e regulatória do país do reator de pesquisar \\ Aspects regarding the legal and regulatory bases of the country where the nuclear research reactor is operating}

2.1) Quem é/são o(s) Orgão(s) Regulador(es) responsável (eis) pelo processo de licenciamento do Reator de pesquisa Nuclear ? Please, Inform the Regulatory Bodies involved on Operating License process?

2.2) A licença de operação do reator de pesquisa nuclear é única e atende a legislação nuclear e ambiental? / Does the nuclear research reactor license operation cover the nuclear and environmental legislation?

Sim, o reator de pesquisa opera sob a concessão de uma licença operacional que considera questões nucleares e ambientais / Yes, it does.

Não. O reator de pesquisa opera sob a concessão de 2 licenças de operação: uma licença de operação nuclear e uma licença de operação ambiental / No, it doesn't. The nuclear research reactor needs two operation licenses: one nuclear operation license and one environmental license.

2.3) As atividades e os experimentos previstos para para serem realizados no reator de pesquisa estão descritos na(s) licença(s) de operação ? Are the experimental activities to be performed in the nuclear research reactor included / described on the operation license?

Sim/Yes $\quad \square \quad$ Não / No

2.4) Outras instalações significantes que estejam no mesmo local podem ser incluídas como parte do reator nuclear e serem incluídas no mesmo processo de licenciamento? / Should others significant facilities located at the same nuclear research reactor site be included on the same licensing process?

2.5) O processo de licenciamento exige a apresentação de planos de emergência ? I Are the emergency plans required to nuclear research reactor licensing process?
Sim. Em que fase?
/ Yes. Which phase?
Não / No 
2.6) O processo de licenciamento exige a apresentação de um plano de proteção física ? / Are the physical protection plans required to nuclear research reactor licensing process?

Sim. Em que fase?

/ Yes. Which phase?

Não / No

2.7) O processo de licenciamento exige a apresentação de programas ambientais? Are the environmental programs required to nuclear research reactor licensing process?

Sim. Quais os programas e em que fase devem ser apresentados? / Yes. Which programs and which phases should be presented?

Não / No

2.8) O processo de licenciamento exige a elaboração de um Relatório de Análise de Segurança ? Is a safety analysis report o required to nuclear research reactor licensing process?

Sim. Em que fase? / / Yes. Which phase?

Não / No

2.9) Quais informações devem conter o Relatório de Análise de Segurança? / Which information should be included on the safety analysis report?

\section{Parte 3- Aspectos relacionados ao Projeto e Construção} Aspects regarding design and construction

3.1) O processo de licenciamento inclui aspectos relacionados ao projeto do reator de pesquisa? Como por exemplo: / Has the licensing process considered general requirements or design? For instance:

3.1.1) Critérios de Projeto / design criteria;

Sim/yes $\square$ Não/No

3.1.2) Normas e Códigos/Standards and codes;

Sim/ yes $\square$ Não/No

3.1.3) Limites de Projeto / Design limits;

Sim/ yes $\square$ Não/No 
3.1.4) Classificação de Sistemas/Classification of systems;

$\square$ Sim/yes $\square$ Não/No;

3.1.5) Proteção ao Meio Ambiente/Environmetal Protection;

$\operatorname{Sim} /$ yes $\square$ Não/No

3.2) O início da construção do reator de pesquisa precisa receber aprovação do órgão regulador? Does the construction start up need to be approved by the regulatory body?

3.3) As atividades de infraestrutura, como exploração de escavação preliminar, preparação de canteiro, vias de acesso, subestação, linhas de transmissão, edificações temporárias podem ser iniciadas sem autorização ou licença do órgão regulador? Could the infrastructure activities as initial earth excavation, assembly of the temporary facilities, construction of streets for accessing to the research reactor facility, electrical transmission lines be started up without any kind authorization or licensing by the regulatory body?

$\square \mathrm{Sim} /$ yes $\square$ Não/No

3.4) Para iniciar a fabricação de componentes da instalação do reator nuclear é necessária autorização do órgão regulador? / Has the beginning of the manufacturing of research reactor components be authorized by the regulatory body?

\section{$\operatorname{Sim} /$ yes $\square$ Não/No}

3.5) Quais as autorizações ambientais são necessárias para o início da construção do reator de pesquisa?/ Wich kinf of environmental authorizations are needed to starting the construction of the research reactor facility?

O início da construção do reator nuclear exige algum tipo de planejamento ambiental? / Is an environmental planning required to start up the construction of research reactor facility?

Sim / yes. Descreva o conteúdo do planejamento ambiental / Please, How is this environmental planning?

Não/No 
Parte 4- Aspectos relacionados ao comissionamento do reator de pesquisa Aspects regarding to the nuclear research reactor commissioning

4.1) O programa de comissionamento do reator nuclear é um documento obrigatório e faz parte do processo de licenciamento? / Is the nuclear research reactor commissioning program a mandatory document of the licensing process?

Sim/ yes $\square$ Não/No

4.2) Quais são os estágios do programa de comissionamento? / Which are the commissioning program stages?

4.3) Há necessidade de autorização do órgão regulador para realizar o comissionamento do reator de pesquisa? / Should the nuclear research reactor commissioning be authorized by the regulatory body?

Sim/ yes $\square$ Não/No

Parte 5- Aspectos relacionados à operação do reator de pesquisa Aspects regarding to the nuclear research reactor operation

5.1) Descreva as atividades ambientais que devem ser apresentadas ao(s) órgão(s) regulador(es) para obtenção da licença de operação/ Could you please describe which environmental activities should be carried out according to the regulatory body to get the environmental licensing?

5.2) Descreva as atividades técnicas necessárias à obtenção da licença de operação , tais como procedimentos, relatórios , autorizações entre outros / Could you please describe the technical activities like procedures, reports, authorizations , etc. to get the environmental licensing?

Parte 6- Aspectos relacionados ao descomissionamento do reator de pesquisa Aspects regarding to the nuclear research reactor decomminioning

6.1) O descomissionamento é considerado no processo de licenciamento do reator de pesquisa ? / Is the decommissioning process included in the the nuclear research reactor decommissioning?

$\operatorname{Sim} /$ yes $\square$ Não/No 
6.2) Se a resposta 6.1 for sim, descreva as atividades requeridas pelo(s) órgão(s) regulador(es) nesta fase. I If Yes, could you please describe the required activities $\square \mathrm{Sim} /$ yes $\square$ Não/No

by the regulatory body?

6.3) Se a resposta 6.1 for não, há necessidade de se obter licença do órgão regulador para o descomissionamento de um reator de pesquisa nuclear? I If No, Is there the need to get license to carry out the decommissioning of a nuclear research reactor?

Sim/ yes $\square$ Não/No

Parte 7- Aspectos relacionados ao programa de garantia da qualidade do reator de pesquisa

Aspects regarding to the nuclear research reactor Quality Assurance Program

7.1) O programa de garantia da qualidade do reator nuclear é uma exigência regulatória? / Is the nuclear research reactor Quality Assurance Program a regulatory requirement?

7.2) Está definido pelo órgão regulador um modelo as ser seguido para elaborar o programa de garantia da qualidade?/ Is there a Quality Assurance Program structure defined by the regulatory body?

Sim/ yes $\square$ Não/No

7.3) Se a resposta 7.2 for SIM, descreva o modelo ou indique a referência normativa seguida/ If Yes, could you please describe the standard to be followed?

7.4) Se a resposta 7.2 for NÃO, descreva o conteúdo do programa de garantia da qualidade de seu reator de pesquisa/ If No, coul you please describe the contents of the Quality Assurance Program applied in your nuclear research reactor?

7.5) Existe algum programa específico implantado em seu reator nuclear por exigência regulatória? Is there any kind of program implemented in your your nuclear research reactor?

Sim. Informe a referência normativa / yes. Please inform the apllied standard

$\square$ Não/No 


\section{REFERÊNCIAS BIBLIOGRÁFICAS}

1. AECL,2010.<//www.aecl.ca/NewsRoom/News/Press2008/080516.htm\#>. Acesso em: 15/04/2010;

2. AIEA. Organization of Regulatory Activities for Nuclear Reactors. 1a. ED. Vienna, STI/DOC/10/153, 1974. (Technical reports series, 153);

3. AIEA. Legal and Governmental Infrastructure for Nuclear, Radiation, Radiactive Waste and Transport Safety. Vienna, 2000. (IAEA Safety Standard Series No. GS-R-1);

4. AECL, 2009. <http://www.aecl.ca/site3.aspx>. Acesso em: 08/09/2009;

5. AIEA, 2009. Research Reactor Data Base. Vienna, 2009. Disponível em $<$ http://www.iaea.org/worldatom/rrdb>. Acesso em: 04 de setembro de 2009;

6. AIEA. Code on the safety of nuclear research reactors: design. 1992. 44 p. (IAEA SS-35-S1; Safety series, 35-S1);

7. ALVARENGA, M. B. LICENCIAMENTO DO REATOR DE PESQUISA IEA-RI ELEVACAO DE POTENCIA DE 2MW PARA 1OMW: SUMARIO EXECUTIVO. RIO DE JANEIRO, 1989;

8. ANDER-EGG, E. Introducción a las técnicas de investicación social para trabajadores sociales, 7. ed. Buenos Aires, Humanitas,1978;

9. Berry, J.L.; Lerouge, B. Licensing procedures and safety criteria for research reactors in France. International meeting on development, fabrication and applications of reduced-enrichment fuels for research and test reactors. Argonne, IL, USA, 1980;

10. Bunge, Mário. La investigación científica: su estrategia y su filosofía. $3^{3}$. Edición. Siglo Veinteuno Editores, 2004;

11. CEA, 2009. Disponível em <http://www.cad.cea.fr/index gb.php>. Cadarache, 2009 Acesso em: 04/09/2009;

12. CEA, 2009. Disponível em <http://www-cadarache.cea.fr/rih/AddOn/osiris gb.pdf>. Acesso em : 04/09/2009;

13. CNSC, 2009. Disponível em http://www.nuclearsafety.gc.ca/eng/licenseesapplicants/licensingproces s/index.cfm\#a2>. Acesso em : 11/09/2009; 
14. E-Kady, AA. Regulatory Steps Taken to Licensing the Operation of ETRR-2 Research Reactor. $7^{\text {th }}$ Conference off Nuclear Sciences \& Applications, Cairo, 2000;

15. Iracane, D., Chaix, P., Alamo A., Jules Horowitz Reactor: a high performance material testing reactor, C.R. Physique, Volume 9, p. 445-456, 2008;

16. IPEN,2010.Disponível em:

<http://www.ipen.br/conteudo/upload/200905221732520.Customer\%20 Notification NRU\%20 19 .pdf>. Acesso em 22/06/2010;

17. IPEN, 2010. Disponível em:

<http://www.ipen.br/conteudo/upload/200905221729160.MDS\%20Nordi on\%20Supply\%20News\%20Relea .pdf > . Acesso em 22/06/2010;

18. KAERI, 2009. Disponível em < http://www.kaeri.re.kr>. Acesso em 08/09/2009;

19. Lakatos, E.M.; Marconi, M.A. Metodologia Científica. $1^{\mathrm{a}}$ Edição. Ed. Atlas, 1983;

20. Lakatos, E.M.;Marconi, M.A. Fundamentos da Metodologia Científica. 7a. Edição. Ed. Atlas, 2010;

21. Lee, A.G.; Labrie, J.P.; Langman, V.J. Licensing of MAPLE reactors in Canada. $7^{\text {th }}$ meeting of the International Group on Research Reactors, Bariloche, 1999;

22. Moon, P.S. THE LICENSING PRACTICE ON NUCLEAR POWER PLANTS IN KOREA. International Nuclear Technology Forum: Future prospects of nuclear plants and Turkey Ankara. Turquia, 1993;

23. Pallas. Project -update January 2009. Disponível em $<$ http://www.pallasreactor.eu/fileadmin/pallasreactor/user/Pallas project update January 2009.pdf $>>$. Acesso em 08/10/2009;

24. Popper, K.S. A lógica da pesquisa científica. $2^{\mathrm{a}}$. Ed. São Paulo, Cultrix, 1975;

25. ROZENTAL, J.J. CONCEITOS SOBRE LICENCIAMENTO DE INSTALAÇÕES NUCLEARES. CNEN, Rio de Janeiro, 1986;

26. Summerfield, M.W., Garea, V.Licensing of ANSTO's Replacement Research Reactor. International Group on Research Reactors 
(Germany) IGORR 9: Proceedings of the $9^{\text {th }}$ Meeting of the International Group on Research Reactors, Sydney, 2003; 


\section{BIBILOGRAFIA RECOMENDADA}

1. AECL, 2009. < http://www.aecl.ca/NewsRoom/News/Press2009/090728.htm\#>. Acesso em 08/09/2009.

2. Ahmed, E.E.M.,Rahman, F.A. Nuclear safety requirements for operation licensing of Egyptian research reactors. International symposium on research reactor utilization, safety and management, Lisboa, 1999.

3. AIEA. The Management System for Facilities and Activities Safety Requirements - Safety Standards Series No. GS-R-3, Viena, 2006.

4. AIEA. Documentation for use in regulating nuclear facilities: safety guide. Vienna, 2002. 42 p. (IAEA-SSS-GS-G-1.4; Safety standards series, GS-G-1.4).

5. AIEA. The Safety of Nuclear Installations. (SAFETY-SERIES-110). VIENNA, 1993.

6. AIEA. Safe operation of critical assemblies and research reactors. 1971 edition: Code of Practice. International Atomic Energy Agency and the World Health Organization and Technical Appendix. Vienna, 1971. 193 p. (IAEA SS-35/1971; Safety series, 35).

7. AIEA. Code on the safety of nuclear research reactors: operation. Vienna, 1992. 44 p. (IAEA SS-35-S2; Safety series, 35-S2).

8. AIEA. Safety of Research Reactors: Safety Requirements No. NSR-4 Vienna, 2005

9. AIEA .The safety of nuclear installations. Vienna: IAEA, 1993. 26 p. (Safety series, n. 110).

10. AIEA. Governmental organization for the regulation of nuclear power plants: a code of practice. Vienna, 1978. 43 p. (IAEA SS-50-CG; Safety series, 50-C-G).

12. AIEA. Safe operation of nuclear power plants: code of practice sponsored by the International Atomic Energy Agency and the World Health Organization and Technical Appendix. Vienna, 1969. 125 p. (IAEA SS-31; Safety series, 31). 
13. AIEA. THE SAFETY OF NUCLEAR INSTALLATIONS. (Safety-Series No.110), VIENNA, 1993.AIEA. Fundamental Safety Principles: safety fundamentals. Vienna, 2006.

14. AIEA. SAFETY ASSESSMENT OF RESEARCH REACTORS AND PREPARATION OF THE SAFETY ANALYSIS REPORT. VIENNA, 1994. (SAFETY SERIES-35-G-1).

15. Almeida, C.The Brazilian experience in licensing Angra 2, a 'delayed' nuclear power plant. International conference on topical issues in nuclear safety, Vienna, 2001;

16. ALVES, R. N. LICENCIAMENTO DE INSTALAÇÕES NUCLEARES. RIO DE JANEIRO: CNEN, 1977;

17. ANSTO. Preliminary Safety Analysis Report (PSAR) - ANSTO Replacement Research Reactor Facility, Vol. 1 e 2, Sydney, 2001.

18. ARPANSA. REGULATORY GUIDE: APPLYING FOR A FACILITY LICENCE FOR A NUCLEAR INSTALLATION, Sydney, 2008.

19. Carvalho, A.J.M. de Licenciamento de instalações nucleares. Uma aproximação em face do Programa Nuclear Brasileiro. Universidade do Estado do Rio de Janeiro (Brazil), 1978.

20. CNEN. Summary of IEA-R1 research a reactor licensing related to its power increase from 2 to $10 \mathrm{MW}$. Licenciamento do reator de pesquisa IEA-R1 - elevação de potencia de $2 \mathrm{MW}$ para 10MW. Rio de Janeiro, 1989.

21. CNEN. LICENCIAMENTO DE INSTALAÇÕES NUCLEARES. RIO DE JANEIRO, 1984.

22. CNEN. Resolução CNEN -15/02 da Comissão Nacional de Energia Nuclear. CNEN-NE-1.04-Licenciamento de Instalações Nucleares. Diário Oficial da União. Brasília, 2002.

23. Clapisson, G.A.; Hill, T.F.; Henderson, N.R.; Keenan, N.H.; Metcalf, P.E.; Mysenkov, A..An overview of the licensing approach of the South African nuclear regulatory authority. Proceedings of a technical committee meeting.,1997, 470 p. p. 139-151;

24. CNSC, 2009. Disponível em: <http://www.aecl.ca/site3.aspx>. Acesso em 05/02/2010. 
25. DIÁRIO OFICIAL DA UNIÃO. LEI Nº 6.189 DE 16 DE DEZEMBRO DE 1974. Brasília, 1974.

26. Dua S. S., An Integrated Performance Based Management System for Nuclear Organizations and its Compliance with National and International Standards, Pacific Nuclear Meeting, Australia, 2006.

27. Ferreli, A.; Paribelli, S.; Valeri, A., at all.Technical bases used in Italy for the licensing of the nuclear power plant. CSNI specialist meeting on regulatory review in the licensing process. Madrid, 1979.

28. Franzen, L.F. Principles and standards of nuclear safety and their implementation. IAEA interregional seminar on nuclear law and safety regulations in developing countries in Africa and the Middle East. Istanbul, 1979.

29. Giuliani, $P$.Regulatory review in the licensing process in NEA member countries. CSNI specialist meeting on regulatory review in the licensing process. Madrid, 1979.

30. Instituto de Pesquisas Energéticas e Nucleares. Relatório de Análise de Segurança do Reator Nuclear IEA-R1, São Paulo, 2012

31. Instituto de Pesquisas Energéticas e Nucleares. Relatório de Análise de Segurança do Reator Nuclear IPEN/MB-01, São Paulo, 2012.

32. IRWIN, A., DE LORENZO, N. OPAL: Commissioning a New Research Reactor. International conference on research reactors: Safe management and effective utilization ,Sydney, 2007 ;

33. Miller, R. New research reactor for Australia. Proceedings of the 2. Meeting of the International Group on Research Reactors, 1992, 501 p. [8 p.].

34. Nuclear Regulatory Commission. Non-Power Reactor Operator licensing Examiner Standards. Washington, DC USA, 1995. 170 p

35. Oury, J.M.Licensing procedure and standardization. CSNI specialist meeting on regulatory review in the licensing process. Madrid, 1979.

36. Prah, M.; Spiler, J. Vojnovic, D.; Pristavec, M. Nuclear licensing in Slovenia. Nuclear Energy in Central Europe 98 Terme Catez, Slovenia, 1998. 
37. Silva, A.J.C. da; Xavier, E.E.Experience acquired by Furnas for licensing nuclear power plants. 80 National Seminar of Production and Transmission of Electric Power. Sao Paulo, 1986.

38. Silva, João B. da R. Normas de Licenciamento de Reatores Nucleares. Belo Horizonte - IPR, 1971.

39. Summerfield, M.W. Licensing of the OPAL Reactor during Construction and Commissioning. International conference on research reactors: safe management and effective utilization, Sydney, 2007.

40. Ward, J.S. Regulatory Review Methods: Review of ANSTO Application for a Facility License to Operate the OPAL Research Reactor in Australia. International conference on research reactors: Safe management and effective utilization, Sydney, 2007.

41. Whelan, D.J.Exporting the Canadian licensing program. 2. Annual conference. Ottawa, 1981.

42. Wu, Jong-Sup; Lee, Ji-Bok . Commissioning status of HANARO Korea Multi-Purpose Reactor. $4^{\text {th }}$ meeting of the International Group on Research Reactors Gatlinburg, TN (United States) 23-25 May 1995.

43. Y. BERGAMASCHI, Y. BOUILLOUX, P. CHANTOIN, B. GUIGON, X. BRAVO, C. GERMAIN, M. ROMMENS, P. TREMODEUX. JULES HOROWITZ REACTOR, BASIC DESIGN. 24. International meeting on Reduced Enrichment for Research and Test Reactors (RERTR) ,Bariloche, 2002.

44. Yehia, H. A., Bars, G., Tran Daï, P. Safety aspects and licensing requirements for new fuel qualification tests and use in research reactors. International meeting on Reduced Enrichment for Research and Test Reactors (RERTR), Bariloche, 2002.

45. ZERBINI, E. J. et al. LICENCIAMENTO DE INSTALAÇÕES NUCLEARES. RIO DE JANEIRO: UERJ, 1977.

46. Zouain, Desiree M. Parques tecnologicos - propondo um modelo conceitual para regioes urbanas - o parque tecnologico de Sao Paulo. 2003. Tese (Doutoramento) - Instituto de Pesquisas Energeticas e Nucleares - IPEN/CNEN-SP, Sao Paulo. 248 p. 